RENATA PAIXÃO

Caracterização de Listeria monocytogenes e Yersinia enterocolitica isoladas em abatedouros e cortes de carne suína no Estado de São Paulo e sua comparação com isolados de casos clínicos em humanos

São Paulo 
RENATA PAIXÃO

\title{
Caracterização de Listeria monocytogenes e Yersinia enterocolitica isoladas em abatedouros e cortes de carne suína no Estado de São Paulo e sua comparação com isolados de casos clínicos em humanos
}

\author{
Tese apresentada ao Programa de Pós- \\ Graduação em Epidemiologia Experimental \\ Aplicada às Zoonoses da Faculdade de \\ Medicina Veterinária e Zootecnia da \\ Universidade de São Paulo para obtenção \\ de título de Doutora em Ciências \\ Departamento: \\ Medicina Veterinária Preventiva e Saúde \\ Animal \\ Área de concentração: \\ Epidemiologia Experimental Aplicada às \\ Zoonoses \\ Orientadora: \\ Profa. Dra. Andrea Micke Moreno
}

\section{São Paulo}


Autorizo a reprodução parcial ou total desta obra, para fins acadêmicos, desde que citada a fonte.

\section{DADOS INTERNACIONAIS DE CATALOGAÇÃO-NA-PUBLICAÇÃO}

(Biblioteca Virginie Buff D’Ápice da Faculdade de Medicina Veterinária e Zootecnia da Universidade de São Paulo)

Paixão, Renata

Caracterização de Listeria monocytogenes e Yersinia enterocolitica isoladas em abatedouros e cortes de carne suína no Estado de São Paulo e sua comparação com isolados de casos clínicos em humanos / Renata Paixão. -- 2010.

$111 \mathrm{f}$ : : il.

Tese (Doutorado) - Universidade de São Paulo. Faculdade de Medicina Veterinária e Zootecnia. Departamento de Medicina Veterinária Preventiva e Saúde Animal, São Paulo, 2010.

Programa de Pós-Graduação: Epidemiologia Experimental Aplicada às Zoonoses. Área de concentração: Epidemiologia Experimental Aplicada às Zoonoses.

Orientador: Profa. Dra. Andrea Micke Moreno.

1. Listeria. 2. Yersinia. 3. Suínos. 4. Humanos. 5. PFGE. I. Título. 


\section{UNIVERSIDADE DE SÃO PAULO \\ Faculdade de Medicina Veterinária e Zootecnia \\ Comissão Bioética}

\section{CERTIFICADO}

Certificamos que o Projeto intitulado "Isolamento e caracterização de Listeria monocytogenes e Yersinia enterocolitica em abatedouros e cortes de carne suína no Estado de São Paulo e sua comparação genotípica com isolados de casos clínicos em humanos", protocolado sob o $\mathrm{n}^{0} 1103 / 2007$, utilizando 360 (trezentos e sessenta) suínos (peças de matadouro), sob a responsabilidade da Profa. Dra. Andréa Micke Moreno, está de acordo com os princípios éticos de experimentação animal da Comissão de Bioética da Faculdade de Medicina Veterinária e Zootecnia da Universidade de São Paulo e foi aprovado em reunião de $23 / 05 / 07$.

(We certify that the Research "Isolation and characterization of Listeria monocytogenes and Yersinia enterocolitica from slaughterhouses and pork from São Paulo State and their genotypic comparison with clinical human isolates", protocol number 1103/2007, utilizing 360 (tree hundred and sixty) swines (parts of slaughterhouses), under the responsibility Profa. Dra. Andréa Micke Moreno, agree with Ethical Principles in Animal Research adopted by Bioethic Commission of the School of Veterinary Medicine and Zootechny of University of São Paulo and was approved in the meeting of the day 05/23/2007).

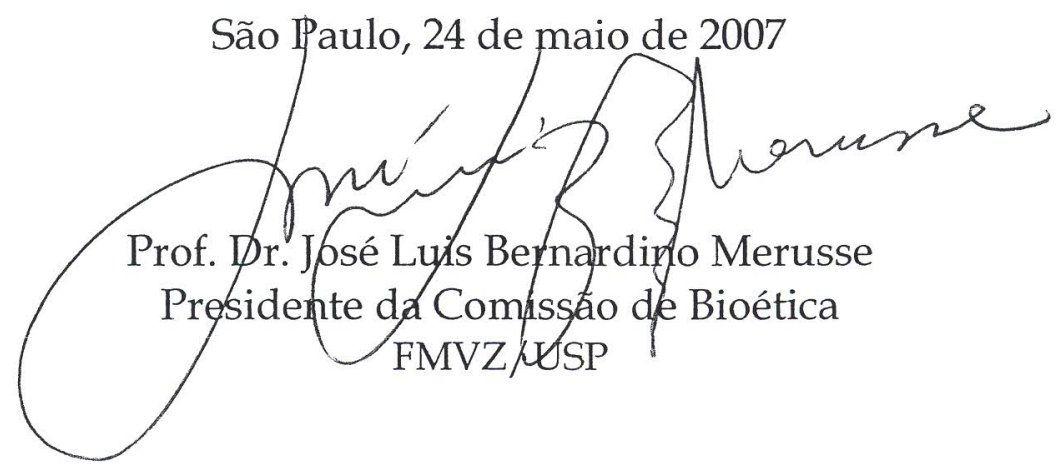

Av. Prof. Dr. Orlando Marques de Paiva, n 87 - 05508-270 - Cidade Universitária "Armando de Salles Oliveira". Fax: (11) 3032-2224 - fones: (11) 309107676/7671 - e-mail: fmvz@edu.usp.br 


\section{FOLHA DE AVALIAÇÃO}

Nome: PAIXÃO, Renata

Título: Caracterização de Listeria monocytogenes e Yersinia enterocolitica isoladas em abatedouros e cortes de carne suína no Estado de São Paulo e sua comparação com isolados de casos clínicos em humanos

Tese apresentada ao Programa de Pósgraduação em Epidemiologia Experimental Aplicada às Zoonoses da Faculdade de Medicina Veterinária e Zootecnia da Universidade de São Paulo para obtenção de título de Doutora em Ciências

Data: ' I

Banca Examinadora

Profa. Dra. Instituição:

Assinatura: Julgamento:

Prof. Dr. Instituição:

Assinatura: Julgamento:

Prof. Dr. Instituição:

Assinatura: Julgamento:

Profa. Dra. Instituição:

Assinatura: Julgamento:

Profa. Dra. Instituição:

Assinatura: Julgamento: 


\section{DEDICATÓRIA}


Aos meus pais, que tanto amo e aos quais tudo devo!

A Deus, que ilumina meu caminho e que sempre me acompanha. 
AGRADECIMENTOS 
À minha orientadora Andrea Micke Moreno que me auxilou em todos os momentos necessários e apoiou minhas idéias durante todo o doutorado e, mais do que isso, a tudo que me ensinou durante estes quase 11 anos de convivência muito obrigada por tudo!

Às minhas grandes amigas, Débora D. S. de Gobbi e Daniele C. Raimundo, as quais chamei de "meus braços direito e esquerdo" durante as épocas de coleta, pois sem elas o trabalho não teria sido possível. A elas também, agradeço ao companheirismo, não só no dia a dia, mas em minha vida pessoal, pois são pessoas especiais!

Às professoras Evelise Oliveira Telles e Simone de Carvalho Balian por terem cedido o espaço de seus laboratórios, onde foi processado o material de quase todo o período de coletas, pois sem esta ajuda este trabalho não poderia ter sido realizado - o meu muito obrigada, do fundo do coração!

À professora Maria Helena Matté, que conheci numa disciplina no início do doutorado e que acabou por se tornar fundamental neste trabalho, demonstrando-se sempre muito solícita, incentivando-me na análise crítica da pesquisa e, mais do que isso, por ter se tornado uma amiga!

Ao Doutor Ernesto Hofer, por toda a ajuda em minha carreira de pesquisadora desde o início do mestrado, e a quem tenho grande respeito e admiração!

Aos técnicos Sandra A. Sanches, Orlando Bispo de Souza, Zenaide M. Morais Higa e Alexandre A. Sanches que me ajudaram em muitos momentos ao longo deste trabalho, pois sem eles teria sido difícil cumprir todos os prazos estipulados.

À bióloga Cristhiane Moura Falavina dos Reis, à pesquisadora Deyse Cristhina Vallim da Silva e ao biólogo André Victor Barbosa, todos do Departamento de Bacteriologia da Fundação Instituto Oswaldo Cruz, no Rio de Janeiro, pela realização da (bio-)sorotipagem dos agentes - reconheço o árduo trabalho que tiveram com o grande número de amostras que foram enviadas e agradeço imensamente a fundamental colaboração que tiveram neste trabalho. Muito obrigada, de verdade!

À amiga Luiza Zanolli Moreno, que aceitou a idéia de trabalhar com as listerias na iniciação científica - que recebeu até uma menção honrosa (que orgulho!) - e agora faz parte da equipe deste grande trabalho que ainda continua! 
Aos amigos de laboratório Ana Paula da Silva, Cleise R. Gomes, Maria Roberta Felizardo, Marina Moreno, Nayla Fernanda de F. Batista, Roberto de A. Bordin, Sergio de M. N. Teixeira e Thais S. P. Ferreira pela ajuda, convivência e companheirismo ao qual dou muito valor na vida - vocês sempre terão um lugar especial em meu coração! (vou sentir saudades...)

Aos amigos da secretaria do departamento Ana Virgínia P. A. Prado, Maria Cristina Paick e Danival L. Moreira, que me ajudaram em muitos momentos durante toda a pós-graduação.

Aos meus grandes amigos Carolina T. Marino e Fábio M. Kaneto por todo o apoio em minha vida, pelas conversas, pelas risadas, pelos abraços, pelo carinho adoro vocês!

Ao meu pai, a minha mãe e ao Luiz que também "entraram na dança" nos sábados de coleta e processamento das amostras.

Aos meus familiares, pelo incentivo que sempre me deram em meu trabalho; pelos conselhos e ombros nos momentos difíceis; pelos momentos de descontração e alegria. Só tenho o que agradecer a Deus quando se fala em família, pois sei que sou privilegiada, e isso é a coisa mais importante na vida! Amo todos vocês...

Ao professor Antônio J. P. Ferreira pela ajuda sempre que Ihe foi solicitada.

À Doutora Juliana Pfrimer Falcão da FCFRP-USP que me cedeu algumas amostras de humanos de Yersinia enterocolitica.

Aos motoristas da faculdade que levaram nossa equipe para que as coletas pudessem ser realizadas.

Aos funcionários, veterinários e proprietários dos abatedouros e mercados em que foram realizadas as coletas.

A todos os estagiários que passaram pelo laboratório enquanto este projeto foi realizado, pois todos tiveram a sua colaboração.

Aos colegas de pós graduação pela convivência.

À FAPESP pelo apoio financeiro e concessão da bolsa de doutorado (proc:06/55501-0).

A um grande amor em minha vida e em meu coração - Luiz Ricardo Burunzuzian - pela convivência, companheirismo, ensinamentos e alegrias. 
RESUMO 


\section{RESUMO}

PAIXÃO, R. Caracterização de Listeria monocytogenes e Yersinia enterocolitica isoladas em abatedouros e cortes de carne suína no Estado de São Paulo e sua comparação com isolados de casos clínicos em humanos. [Characterization of Listeria monocytogenes and Yersinia enterocolitica isolated from slaughterhouses and pork in São Paulo State and their comparision with isolates from clinic cases in humans]. 2010. 111f. Tese (Doutorado em Ciências) - Faculdade de Medicina Veterinária e Zootecnia, Universidade de São Paulo, São Paulo, 2010.

Listeria monocytogenes e Yersinia enterocolitica são agentes zoonóticos e têm capacidade de transmissão através dos alimentos, inclusive carne suína. O presente estudo avaliou, mensalmente, de maio de 2007 a abril de 2008, alguns pontos da cadeia produtiva da carne suína em abatedouros e açougues do Estado de São Paulo. Foram avaliados ambientes dos estabelecimentos visitados e amostras de línguas, tonsilas e cortes de carne suína. Listeria monocytogenes foi isolada de todos os tipos de amostra, com presença dos sorotipos 4b, 1/2b, 1/2a e 1/2c. Estes isolados demonstraram grande similaridade, sugerindo até que haja persistência do agente em ambiente, de acordo com a PFGE, reforçando seu potencial de transmissão para humanos. Yersinia enterocolitica 4/ $0: 3$ foi detectada exclusivamente em abatedouros, principalmente nos animais, apresentando, portanto, menor potencial de transmissão para humanos. Entretanto, Yersinia enterocolitica 1A, considerada não patogênica, foi isolada de todos os tipos de amostras, e a maioria apresentou fatores de virulência, devendo este fato ser melhor investigado. Os resultados apresentados indicam a necessidade de se tomar medidas para controle e prevenção da disseminação dos agentes, principalmente da Listeria monocytogenes.

Palavras-chave: Listeria. Yersinia. Suínos. Humanos. PFGE. 
ABSTRACT 


\begin{abstract}
PAIXÃO, R. Characterization of Listeria monocytogenes and Yersinia enterocolitica isolated from slaughterhouses and pork in São Paulo State and their comparision with isolates from clinic cases in humans. [Caracterização de Listeria monocytogenes e Yersinia enterocolitica isoladas em abatedouros e cortes de carne suína no Estado de São Paulo e sua comparação com isolados de casos clínicos em humanos]. 2010. 111f. Tese (Doutorado em Ciências) - Faculdade de Medicina Veterinária e Zootecnia, Universidade de São Paulo, São Paulo, 2010.
\end{abstract}

Listeria monocytogenes and Yersinia enterocolitica are zoonotic agents with capacity of transmission through foods, including pork. The present study evaluated, monthly, from May 2007 to April 2008, several points of swine meat productive chain in slaughterhouses and butcheries from Sao Paulo state. It were evaluated the environments of visited establishments and samples of tongues, tonsils and pork cuts. Listeria monocytogenes was isolated from all kinds of samples and the serotypes $4 b, 1 / 2 b, 1 / 2 a$ and $1 / 2 c$ were present. These isolates showed great similarity, even suggesting that there was persistence of the agent in the environment, according to the PFGE, reinforcing its potential of transmission to humans. Yersinia enterocolitica 4/ 0:3 was exclusively detected in slaughterhouses, mainly in the animals, presenting therefore, low potential of transmission to humans. However, Yersinia enterocolitica 1A, considered no pathogenic, was isolated from all kinds of samples, and the majority presented virulence factors, suggesting that this observation should be better investigated. The results presented indicate the necessity of measures of control and prevention of agent's dissemination, mainly of Listeria monocytogenes.

Keywords: Listeria. Yersinia. Swine. Humans. PFGE. 
SUMÁRIO 
1 INTRODUÇÃO

1.1 LISTERIA MONOCYTOGENES..................................................... 18

1.2 YERSINIA ENTEROCOLITICA............................................................ 20

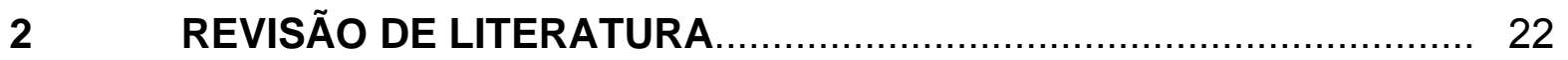

$2.1 \quad$ LISTERIA MONOCYTOGENES........................................................ 22

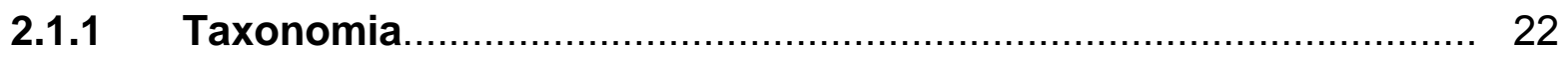

2.1.2 Características microbiológicas e fenotípicas ................................ 22

2.1.3 Mecanismos de virulência ........................................................ 23

2.1.4 Listeriose humana ................................................................. 25

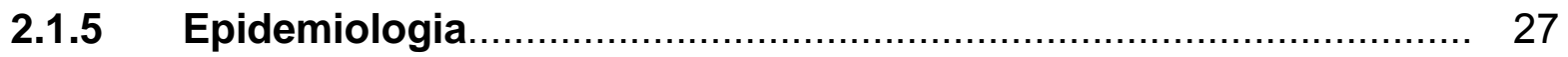

2.1.6 Listeria em alimentos............................................................. 28

2.1.7 Métodos de deteç̧ão................................................................... 30

2.1.7.1 Métodos Convencionais............................................................ 30

2.1.7.2 Métodos Alternativos.................................................................. 32

2.1.8 Caracterização genotípica ......................................................... 32

2.1.9 Controle e prevenção................................................................. 33

2.2 YERSINIA ENTEROCOLITICA.......................................................... 34

2.2.1 Taxonomia

2.2.2 Características microbiológicas e fenotípicas.............................. 34

2.2.3 Mecanismos de virulência ............................................................. 35

2.2.4 Yersiniose humana ........................................................... 37

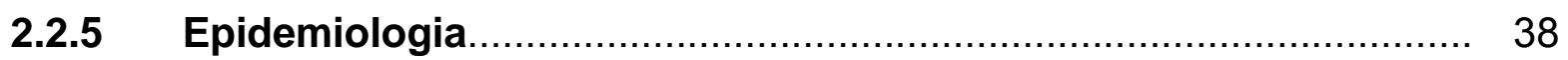

2.2.6 Yersinia em alimentos............................................................. 39

2.2.7 Métodos de deteç̧ão ............................................................. 40

2.2.7.1 Métodos Convencionais................................................................ 40

2.2.7.2 Métodos Alternativos.................................................................... 41

2.2.8 Caracterização genotípica............................................................ 41

2.2.9 Controle e prevenção............................................................ 42

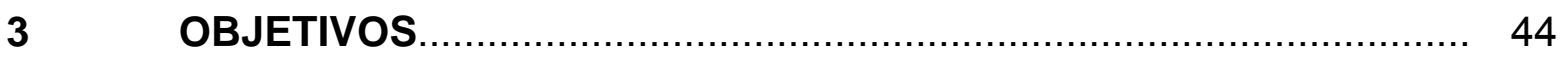




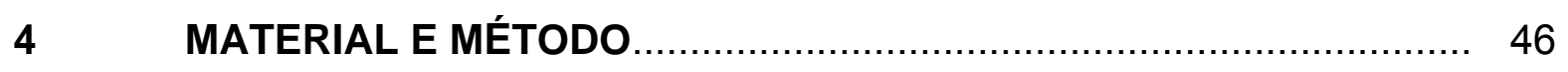

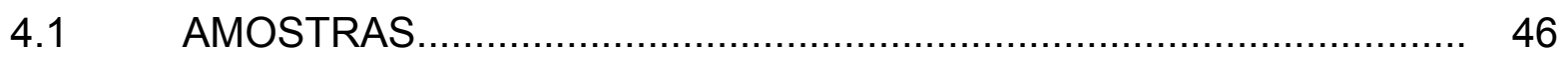

4.2 COLHEITA DAS AMOSTRAS........................................................ 46

4.3 EXAME BACTERIOLÓGICO....................................................... 47

4.3.1 Listeria monocytogenes....................................................... 47

4.3.1.1 Suabes de língua e tonsilas e de ambientes..................................... 47

4.3.1.2 Carnes................................................................................. 48

4.3.2 Yersinia enterocolitica ................................................................. 50

4.3.2.1 Suabes de língua e tonsilas e de ambientes..................................... 50

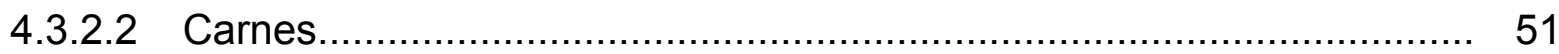

4.4 DETERMINAÇÃO DOS SOROTIPOS DOS ISOLADOS..................... 53

4.5 REAÇÃO EM CADEIA PELA POLIMERASE (PCR) ......................... 53

4.5.1 Extração de DNA ................................................................. 53

4.5.2 Amplificação do DNA …………………................................ 54

4.5.2.1 Listeria monocytogenes............................................................. 54

4.5.2.2 Yersinia enterocolitica............................................................... 54

4.5.3 Deteç̧ão do produto de amplificação (amplicon) ........................... 55

4.6 ELETROFORESE EM CAMPO PULSADO (PFGE)........................... 55

4.6.1 Análise estatística ................................................................. 56

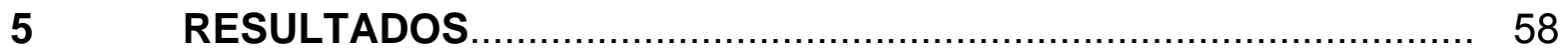

5.1 LISTERIA MONOCYTOGENES....................................................... 58

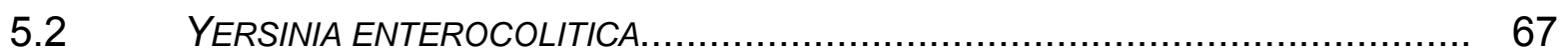

$6 \quad$ DISCUSSÃO

6.1 LISTERIA MONOCYTOGENES..................................................... 79

6.2 YERSINIA ENTEROCOLITICA............................................................. 86

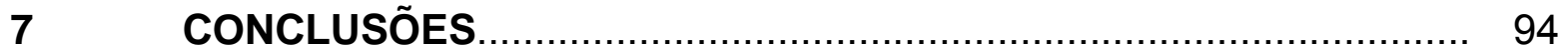

7.1 LISTERIA MONOCYTOGENES.......................................................... 94

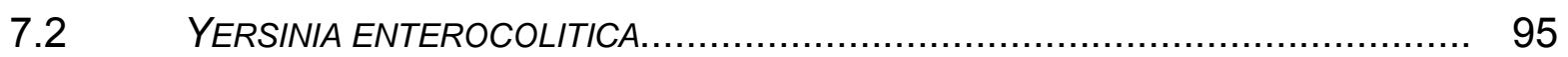

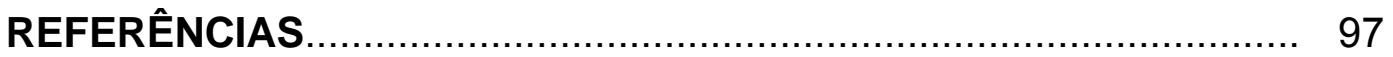


INTRODUÇÃO 


\section{INTRODUÇÃO}

\subsection{LISTERIA MONOCYTOGENES}

A listeriose é causada por microorganismos do gênero Listeria que tem característica cosmopolita e atinge o homem e os animais (LOW; DONACHIE, 1997). A Listeria monocytogenes é a espécie mais importante e foi descrita pela primeira vez por Murray, Webb e Swan (1926) recebendo o nome de Bacterium monocytogenes devido à monocitose característica observada na infecção natural e experimental de coelhos e cobaios. Em 1927, Pirie renomeou-a como Listerella hepatolytica sendo que, na década de 40 , este mesmo autor sugeriu a mudança do gênero para Listeria, mantendo sua denominação atual. Os primeiros relatos do isolamento do agente ocorreram em 1929 por Gill em ovelhas e por Nyfeldt em humanos (GRAY; KILLINGER, 1966). Desde então, casos esporádicos de listeriose foram descritos, em geral em trabalhadores que lidavam com animais infectados. A partir da década de 80 , o número de casos em humanos aumentou em diversos países, juntamente com a evidência da transmissão do agente por alimentos, fato que renovou o interesse de pesquisadores, bem como de órgãos governamentais e indústrias alimentícias em estudar a L. monocytogenes (FARBER; PETERKIN, 1991; MCLAUCHLIN, 1996).

Os alimentos que têm sido associados aos surtos de listeriose incluem vegetais, ovos, frutos do mar e produtos lácteos e cárneos, estando entre eles os produtos de origem suína, como pork tongue in jelly (JACQUET et al., 1995), pork 'rillettes' (GOULET et al., 1998), carne moída (SKOVGAARD; NØRRUNG, 1989), salsicha e salame (JAY, 1996). No Brasil nenhum surto de listeriose foi notificado até o momento, mas alguns trabalhos relatam a contaminação de queijos (SILVA et al., 2001; PIMENTA et al., 1999), salsichas (PIMENTA et al., 1999; PETTINATI, 2004; DEGENHARDT; SANT'ANNA, 2007), salames (BORGES et al., 1999) e lingüiças (DUVAL et al., 2003; SILVA et al., 2004) por L. monocytogenes, bem como seu isolamento de material clínico humano, como placentas e abortos (SCHWAB; EDELWEISS, 2003), líquido cefalorraquidiano (HOFER; NASCIMENTO; OLIVEIRA, 
1998), sangue e fezes (HOFER; REIS; HOFER, 2006). Nos últimos anos, vários estudos têm relacionado a presença do agente em carcaça suína com a contaminação desta a partir das fezes de animais portadores e/ou com a contaminação dos equipamentos de processamento dos produtos cárneos (SKOVGAARD; NØRRUNG, 1989; AUTIO et al., 2000; CHASSEIGNAUX et al., 2001; BELOEIL et al., 2003). Para tanto, isolados de L. monocytogenes das fezes e carcaças de suínos provenientes de granjas e/ou abatedouros, bem como de ambientes e equipamentos, são caracterizados fenotípica e genotipicamente, a fim de se identificar a origem da contaminação. A sorotipagem, um método fenotípico, é o primeiro passo da caracterização do agente, mas não é suficientemente discriminatório (CHASSEIGNAUX et al., 2001); métodos genotípicos como a reação em cadeia pela polimerase (PCR) também são utilizados. Diversas técnicas moleculares que apresentam alto poder discriminatório foram desenvolvidas, sendo a eletroforese em campo pulsado (PFGE) considerada a técnica 'gold standard' em estudos epidemiológicos na atualidade. Deste modo, há a possibilidade de se fazer um rastreamento molecular comparando-se os isolados provenientes de diversos pontos da cadeia (DAUPHIN; RAGIMBEAU; MALLE, 2000).

Considerando a importância dos produtos de origem suína em vários surtos de infecção humana na Europa e a presença do agente em animais e abatedouros em nosso país (PAIXÃO, 2006), o presente estudo teve por objetivos o isolamento de L. monocytogenes em diferentes pontos de abatedouros - animal e ambiente bem como em carne suína e ambientes de mercados, sua posterior caracterização fenotípica e genotípica, e sua comparação entre si e com isolados de casos clínicos de humanos, a fim de se supor possíveis pontos da contaminação. 


\subsection{YERSINIA ENTEROCOLITICA}

A bactéria foi descrita pela primeira vez em 1934 por Mclver e Pike como Flavobacterium pseudomallei. Em 1939, Schleifstein e Coleman propuseram o nome Bacterium enterocoliticum, por ter sido isolado de conteúdo entérico. Por fim, o nome Yersinia enterocolitica foi introduzido na família das Enterobacteriaceae em 1964, por Frederiksen (BOTTONE, 1997).

A $Y$. enterocolitica é um patógeno emergente transmitido por alimentos, de importância em saúde pública e de disseminação cosmopolita (LEAL; LEAL; ALMEIDA, 1997), sendo o bio-sorotipo 4/O:3 o mais comumente associado com a yersiniose em humanos na Europa (GÜRTLER et al., 2005). Nos últimos anos, a $Y$. enterocolitica vem sendo detectada em várias espécies de animais domésticos, sendo o suíno considerado o principal reservatório, por ser portador são de isolados dos mesmos bio-sorotipos encontrados em humanos (MENDONÇA et al., 1995), demonstrando associação entre a doença e o consumo de produtos de origem suína (GÜRTLER et al., 2005). Entretanto, a epidemiologia da doença ainda é obscura (ASPLUND et al., 1990; BOER; NOUWS, 1991). A partir de então, diversos estudos vêm sendo realizados a fim de se determinar a prevalência do agente em suínos abatidos, ambientes de abatedouros e carne suína (ASPLUND et al., 1990; MENDONÇA et al., 1995; LAMBERTZ; DANIELSSON-THAM, 2005). No Brasil, existem estudos sobre a prevalência do agente em suínos vivos (MENDONÇA et al., 1995; HOFER; LÁZARO, 1997; LEAL; LEAL; ALMEIDA, 1997), suínos abatidos (TEODORO, et al., 2006) e alimentos (ALBUQUERQUE; CARDOSO, 1999; FALCÃO et al., 2006); entretanto, não há estudos a respeito da epidemiologia deste agente na cadeia de produção da carne suína no país.

Considerando o papel da carne suína como fonte de infecção da doença, propôs-se: isolar o agente em diferentes pontos do abatedouro - animal e ambiente - bem como em carne suína e ambientes de mercados; caracterizá-los fenotípica e genotipicamente, e compará-los entre si e com isolados de casos clínicos de humanos, a fim de se evidenciar supostos pontos da contaminação. 
REVISÃO DE LITERATURA 


\section{REVISÃO DE LITERATURA}

\subsection{LISTERIA MONOCYTOGENES}

\subsubsection{Taxonomia}

Listeria monocytogenes era a única espécie reconhecida no gênero até 1961. Nos anos subseqüentes, outras espécies foram adicionadas e algumas destas retiradas, sendo que, atualmente, pertencem ao gênero Listeria: L. monocytogenes, L. ivanovii, L. innocua, L. seeligeri, L. welshimeri e L. grayi, de acordo com estudos fenotípicos e genotípicos realizados (LOW; DONACHIE, 1997).

As infecções clínicas nos homens e nos animais são causadas pela $L$. monocytogenes, mas a L. ivanovii também é patogênica, estando associada com abortos em ruminantes; as demais espécies são consideradas não patogênicas (FARBER; PETERKIN, 1991).

\subsubsection{Características microbiológicas e fenotípicas}

A L. monocytogenes é um bacilo gram positivo, não formador de esporos, com 1 a $2 \mu \mathrm{m}$ de comprimento e 0,5 $\mu \mathrm{m}$ de largura, freqüentemente estando paralelas umas às outras, em paliçada, e alinhadas em algumas culturas (LOW; DONACHIE, 1997). Seu crescimento ocorre de $-0,4$ a $50^{\circ} \mathrm{C}$, sendo a temperatura ótima de crescimento de 30 a $37^{\circ} \mathrm{C}$ (JUNTTILA; NIEMAL; HIRN, 1988). O agente multiplica-se prontamente em aerobiose ou em condições de microaerofilia e em valores de pH entre 5,6 e 9,6. Apresenta motilidade característica devido à presença de flagelos peritríquios, sendo que a flagelina, responsável por sua formação, é 
melhor expressada em temperaturas de 20 a $25^{\circ} \mathrm{C}$ (PEEL; DONACHIE; SHAW, 1988).

As diferentes espécies do gênero Listeria são negativas para oxidase e indol, e positivas para catalase, embora alguns autores tenham isolado L. monocytogenes negativa para catalase (BUBERT et al., 1997); são positivas na reação de VogesProskauer e hidrolisam a esculina; não hidrolisam uréia, não reduzem nitrato, e também não liquefazem gelatina.

A diferenciação entre as espécies inclui a presença de hemólise em ágar sangue, sendo L. monocytogenes, L. ivanovii e L. seeligeri hemolíticas. A L. monocytogenes pode ter sua hemólise aumentada quando semeada com estria de Staphylococcus aureus, onde sua $\beta$-hemolisina (listeriolisina $O$ ) atua sinergicamente com a do S. aureus, sendo este efeito conhecido como fator de CAMP, descrito por Christie, Atkins e Munch-Petersen (1944); este teste é realizado também com Rhodococcus equi. A identificação bioquímica inclui ainda a fermentação de Lrhamnose, $d$ - xilose, $d$ - manitol e a-metil $d$-mannoside (LOW; DONACHIE, 1997).

Para se concluir a caracterização fenotípica e diferenciar as espécies do gênero Listeria, realiza-se a sorotipagem baseada nos antígenos somáticos $(O)$ e flagelares $(H)$. Esta metodologia consiste de provas de soroaglutinação rápida e lenta, utilizando anti-soros policlonais somáticos e flagelares polivalentes e monovalentes, segundo Seeliger e Höhne (1979).

\subsubsection{Mecanismos de virulência}

A L. monocytogenes é um patógeno intracelular facultativo que tem como hospedeiros o homem e os animais. Uma vez dentro do hospedeiro, este patógeno tem a capacidade de invadir células fagocíticas e não fagocíticas, replicar-se no interior da célula e se difundir diretamente de célula a célula, escapando da resposta imune humoral (CABANES et al., 2004). Cada passo deste processo de infecção é dependente da produção de fatores de virulência, sendo que estes são cada vez mais estudados. 
A infecção pela L. monocytogenes é causada pela disseminação bacteriana a partir da luz intestinal para o sistema nervoso central e a unidade feto-placentária, fato ocorrido devido à capacidade do agente em cruzar estas barreiras (LORBER, 1996). A internalina é uma proteína de superfície da $L$. monocytogenes, e não de outras listerias, que promove a internalização da bactéria em células do epitélio intestinal de humanos ao interagir com receptores E-cadherina presentes nas junções, e não em sua parte apical. Esta interação é o primeiro passo crítico para o início da listeriose in vivo, sendo esta fase intestinal quase 'silenciosa'; entretanto, relatos indicam que a ingestão de grande número de $L$. monocytogenes (acima de $3,0 \times 10^{11}$ UFC/ indivíduo) esteja associada com gastroenterites (LECUIT et al., 2001). A internalina (Inl) responsável pela interação com o receptor E-cadherina é a InIA, o que leva a um rearranjo do citoesqueleto no local, facilitando a entrada do agente no enterócito; outra internalina, a InIB, juntamente com outra proteína de superfície - Ami - estão associadas com a entrada da bactéria em hepatócitos, fibroblastos e células epiteliais e na adesão de células eucarióticas, respectivamente (LECUIT et al., 1999; CABANES et al., 2004). Há ainda outras internalinas que parecem ter importante papel em estágios pós-intestinais da infecção pela $L$. monocytogenes, que são as InIC e InIJ ou Imo2821 (LIU et al., 2007). Além disso, por promover a invasão de enterócitos e a translocação através da barreira intestinal, a internalina também media o acesso a tecidos profundos e deveria ser considerada um fator de virulência tão importante quanto a listeriolisina $\mathrm{O}(\mathrm{LLO})$ e a ActA.

Após entrar nas células, a L. monocytogenes situa-se em um vacúolo primário de uma única membrana, que é lisado pela hemolisina produzida por este agente, a LLO, juntamente com a PIcA (fosfatidilinositol fosfolipase C - PIPLC), o que permite seu crescimento no citoplasma (LIU et al., 2007). Quando livre no citoplasma, a $L$. monocytogenes é protegida de danos oxidativos de fagócitos por produzir catalase e superóxido dismutase (FARBER; PETERKIN, 1991). A bactéria enfim se multiplica e outro fator de virulência entra em ação, a ActA, que é uma proteína que induz a polimerização da actina polarizada, gerando força para o movimento da $L$. monocytogenes no citoplasma (COSSART, 2000). Com o movimento contra a membrana citoplasmática, a $L$. monocytogenes é envelopada em uma estrutura semelhante ao filopodium, que serão englobadas pelas células adjacentes, conduzindo à formação de um vacúolo secundário com dupla membrana; a lise 
deste vacúolo inicia um novo ciclo da infecção que ocorre pela ação da proteína PlcB (fosfatidilcolina fosfolipase C) que é ativada pela Mpl (metaloproteína). Todas essas proteínas associadas à virulência tem seus genes codificadores localizados um adjacente ao outro em mesmo cluster de virulência o qual é regulado por um regulador de virulência pleiotrófico denominado PrfA. Alterações nos genes prfA, plcA, plcB, hly (LLO), actA e inlA (deleção, inserção ou substituição) freqüentemente reduzem a virulência e a patogenicidade; entretanto, este cluster pode estar presente também em outras espécies do gênero Listeria. Recentemente o completo seqüenciamento genômico de vários isolados de Listeria capacitou a identificação de novos genes específicos de virulência em L. monocytogenes, como o Imo2821, confirmado como inlJ, que existe somente em isolados capazes de causar mortalidade em ratos, em testes in vitro, sugerindo seu potencial papel na virulência do agente, já que sorotipos patogênicos mantêm este gene inteiro e funcional, enquanto que sorotipos não patogênicos não o mantêm (LIU et al., 2007). Outros possíveis genes reguladores detectados ainda estão sendo estudados no que diz respeito a virulência de isolados.

\subsubsection{Listeriose humana}

A L. monocytogenes parece ser um residente normal da flora do trato intestinal dos humanos (GRAY; KILLINGER, 1966); isto explica porque anticorpos contra Listeria spp. são comumente encontrados em indivíduos saudáveis. Assim, por causa da alta taxa nesses indivíduos que carreiam L. monocytogenes, este dado não necessariamente indica a infecção (FARBER; PETERKIN, 1991).

Grande parte dos indivíduos com doença clínica apresenta supressão na resposta imune mediada por células $\mathrm{T}$, sendo a ocorrência entre pessoas com síndrome da imunodeficiência adquirida (AIDS) 150 vezes maior do que na população geral da mesma idade, segundo pesquisas realizadas nos Estados Unidos (GELLIN et al., 1991). Outras condições predisponentes que são freqüentemente associadas com a listeriose incluem doenças neoplásicas, transplantes, imunossupressão, gravidez, extremos de idade (neonatos e idosos), 
Diabettes mellitus, alcoolismo e doenças cardiovasculares e renais (NIEMAN; LORBER, 1980). Entretanto, há casos em que indivíduos saudáveis tornam-se infectados pela $L$. monocytogenes em surtos da doença transmitida por alimentos (SCHLECH et al., 1983) e em casos esporádicos (AZADIAN; FINNERTY; PEARSON, 1989).

As manifestações clínicas da infecção por L. monocytogenes podem ser granulomatose infantisséptica em neonatos, meningite, meningoencefalite, encefalite, endocardite, forma cutânea, septicemia, forma ocular, forma cervicoglandular entre outras (RYSER; MARTH, 1991).

Em adultos, a listeriose é geralmente caracterizada pela infecção do sistema nervoso central e bacteremia, podendo ocorrer endocardite. Casos de infecção focal podem ocorrer afetando diferentes partes do corpo, como articulações, fígado e pulmões. Casos de meningite ou encefalite levam a sintomas como cefaléia, vômito, febre e mal estar e estão associados com uma alta taxa de mortalidade (FARBER; PETERKIN, 1991).

Em gestantes, a listeriose leva ao aborto freqüentemente no terceiro trimestre da gestação, havendo relatos de aborto por L. monocytogenes também nos dois primeiros trimestres. Os sintomas nas mães são semelhantes aos de uma gripe, seguidos por diminuição nos movimentos fetais e trabalho de parto prematuro podendo, raramente, ser acompanhados por diarréia e dores lombares - gestantes imunossuprimidas são mais suscetíveis. No neonato, a listeriose surge em duas formas clínicas: a forma de manifestação precoce e a de manifestação tardia. Na forma precoce, os sintomas surgem cerca de 36 horas após o nascimento e, provavelmente, é decorrente da infecção intra-uterina, quando o agente se dissemina pelo organismo atingindo principalmente o fígado e a placenta; neste caso, a doença é conhecida como granulomatose infantisséptica. Na forma tardia, os sintomas aparecem 14 dias após o nascimento, sendo a meningite a principal manifestação clínica observada. A fonte do agente nesta forma não está clara, mas há indícios de que a criança se contamine a partir do trato genital da mãe durante o parto (MCLAUCHLIN, 1990).

Embora alguns indivíduos possam se recuperar espontaneamente, a realização de uma antibioticoterapia a tempo pode prevenir seqüelas e até mesmo a morte (RYSER; MARTH, 1991). A maioria dos isolados de L. monocytogenes são 
sensíveis a vários antibióticos in vitro, mas in vivo uma baixa eficiência pode ser esperada, o que ocorre, em parte, devido à localização intracelular do microorganismo. Assim, ampicilina ou amoxacilina associadas a gentamicina, são a primeira escolha no tratamento para listeriose em humanos (HOF, 1991).

No Brasil, há relatos de meningite causada por L. monocytogenes em São Paulo (ESPER et al., 1978), Recife (LEAL et al., 1983) e Distrito Federal (HOFER; NASCIMENTO; OLIVEIRA, 1998), infecção neonatal e abortos no Rio Grande do Sul (PIVA et al., 1987; SCHWAB; EDELWEISS, 2003) e diarréia em paciente HIV positivo no Rio de Janeiro (NORBERG et al., 2004). Hofer, Nascimento e Oliveira (1998) sugerem que o pequeno número de relatos da infecção no país possa ser decorrente de falha no diagnóstico laboratorial ou de utilização de antibioticoterapia prévia, o que inibiria o isolamento do agente.

\subsubsection{Epidemiologia}

L. monocytogenes está amplamente distribuída no ambiente e pode ser isolada de diversas fontes, como: solo, vegetação, matéria fecal, esgoto e água (RYSER; MARTH, 1991). O isolamento da bactéria também foi obtido de bovinos, ovinos, caprinos, aves, suínos e animais silvestres (GRAY; KILLINGER, 1966; CHASSEIGNAUX et al., 2001). Estudos apontam a freqüência do agente nas fezes de portadores sãos variando de 0,5 a 91,7\%, em diferentes grupos pesquisados, variando também entre as diferentes espécies animais. Skovgaard e Morgen (1988) descrevem uma freqüência de eliminação de $52 \%$ em bovinos leiteiros, enquanto Kanuganti et al. (2002) afirmam que em suínos varia de 0 a $47 \%$. Assim, os animais de produção podem se tornar mais uma fonte de contaminação do ambiente de abatedouro e, conseqüentemente, fonte de infecção para humanos por terem seus produtos e subprodutos (cárneos e lácteos) contaminados pelo agente neste ambiente. Isto tem sido proposto e estudado desde o início da década de 80 , quando surtos de listeriose transmitida por alimentos foram descritos, algumas vezes podendo a taxa de mortalidade alcançar até $75 \%$ em indivíduos altamente suscetíveis (BELOEIL et al., 2003). 
Desde então, a incidência de listeriose tem crescido em todo o mundo com o aumento do número de casos principalmente na Europa. Não se sabe o quanto este aumento é resultado da melhoria no sistema de diagnóstico e/ou conscientização da população mas, sem dúvida, a população suscetível está aumentando e a quantidade e variedade de alimentos em que a Listeria é capaz de sobreviver e multiplicar-se também (FARBER; PETERKIN, 1991).

Relatos de listeriose no Brasil envolvendo grande número de pessoas e associados a algum tipo específico de alimento contaminado não foram observados na literatura consultada. Esta lacuna pode estar relacionada a deficiências na investigação deste tipo de ocorrência no país ou, o que é menos provável, ao baixo risco de contaminação dos alimentos. Em estudo realizado por Hofer, Ribeiro e Feitosa (2000), foram caracterizadas 3.112 amostras do gênero Listeria de diferentes origens, isoladas no Brasil entre 1971 e 1997. Dentre estes, 774 amostras $(24,8 \%)$ eram L. monocytogenes isoladas a partir de humanos, bovinos, carne de frango, esgoto, solo e vegetais, revelando que o agente é prevalente em nosso meio.

Apesar de existirem 13 sorotipos de L. monocytogenes capazes de causar listeriose em humanos, os sorotipos $4 b, 1 / 2 b$ e 1/2a causam a maioria dos casos (98\%, segundo LIU, 2006), inclusive dentre os relatados no Brasil (FARBER; PETERKIN, 1991; HOFER; RIBEIRO; FEITOSA, 2000). Dentre estes, o sorotipo 4b é o mais relacionado com a doença em humanos nos casos onde há surtos epidêmicos, como mostram dados dos Estados Unidos (34\%) e do Reino Unido (64\%), e os sorotipos $1 / 2 \mathrm{a}$ ( $30 \%$ e $15 \%$, respectivamente) e $1 / 2 \mathrm{~b}$ ( $32 \%$ e $10 \%$, respectivamente) relacionados aos casos de infecções esporádicas (WIEDMANN, 2002).

\subsubsection{Listeria em alimentos}

O fato da Listeria ser ubiqüitária e estar presente no ambiente e nas fezes dos animais facilita a sua presença nos alimentos, principalmente quando estes sofrem manipulação ou são processados. A transmissão do agente por alimentos 
contaminados era desconhecida até a década de 80. No entanto, um surto envolvendo 41 casos ocorrido no Canadá entre março e setembro de 1981 tornou-se um modelo para os estudos epidemiológicos sobre listeriose (SCHLECH et al., 1983). Neste surto ocorreram 34 infecções perinatais com 9 abortos e mortalidade de $27 \%$ entre os nascidos vivos. Dentre os 7 adultos a mortalidade foi de $28,6 \%$. Como resultado de um estudo caso-controle realizado verificou-se que uma salada de repolho crua preparada por um comerciante local foi a responsável pelos casos. A salada mantida no refrigerador de um dos pacientes foi examinada e continha $L$ monocytogenes sorotipo 4b, o mesmo envolvido nestes casos de listeriose. Uma investigação sobre as possíveis fontes de contaminação do alimento foi realizada e verificou-se que um dos produtores de repolho da região adubava sua plantação com esterco de ovinos e que no ano anterior dois animais haviam morrido de listeriose nesta criação. Após a colheita, o repolho havia sido mantido sob refrigeração, o que deve ter favorecido o crescimento da $L$. monocytogenes neste substrato (FARBER; PETERKIN, 1991).

Após este primeiro surto de listeriose ocasionado por alimento confirmado pelo isolamento do agente, outros alimentos foram responsáveis por surtos, tais como: queijos, leite cru, vegetais e ovos. A contaminação de produtos lácteos por $L$. monocytogenes tem sido amplamente estudada. Dentre estes produtos, os queijos frescos são os mais pesquisados devido à grande associação destes com casos de listeriose. O crescimento do agente tem sido demonstrado em derivados do leite contaminados natural e artificialmente, mantidos de $4^{\circ}$ a $35^{\circ} \mathrm{C}$, e observa-se que a presença de bactérias psicotróficas do leite não afeta o crescimento da Listeria (MARSHALL; SCHMIDT, 1988).

Mais recentemente, na década de 90, outros alimentos estiveram envolvidos com casos de listeriose, sendo a maioria de produtos cárneos, destacando-se muitos de origem suína - salsichas, lingüiças, salame e outras carnes suínas (FARBER; PETERKIN, 1991). Nestes produtos a concentração do agente em UFC/g varia amplamente. Glass e Doyle (1989) descrevem que o crescimento do microrganismo em carne é dependente do tipo de carne e do $\mathrm{pH}$. O agente cresce muito bem em pH próximo ou superior a 6,0; no entanto, o crescimento é pobre quando próximo ou abaixo do pH 5,0. A carne de frango parece ser a que apresenta melhores condições para o crescimento da bactéria. Já em rosbifes, lingüiças ou salsichas o crescimento 
é menos favorecido. Nestes produtos parece haver uma associação entre o $\mathrm{pH}$, a atividade de água e a fumaça líquida como inibidores do crescimento (GLASS; DOYLE, 1989).

O sorotipo de Listeria mais freqüente em derivados de carne e leite é o sorotipo 1, mas vários autores têm isolado o sorotipo $4 \mathrm{~b}$ em produtos cárneos (MORRIS; RIBEIRO, 1989). Apesar de menos freqüentes, relatos de listeriose causada pelo sorotipo 1 têm sido descritos na literatura (FARBER; PETERKIN, 1991).

Assim como os produtos de origem animal, os vegetais têm sido estudados em relação à contaminação por L. monocytogenes, sendo também o sorotipo 10 mais freqüente; neste tipo de alimento, a ocorrência do agente é relatada em misturas para saladas pré-lavadas e cortadas (VELANI; ROBERTS, 1991). Os peixes e frutos do mar também são alvos de pesquisa quanto à presença e ao crescimento de Listeria, e parecem estar associados a casos esporádicos da doença (FARBER; PETERKIN, 1991).

\subsubsection{Métodos de detecção}

A listeriose pode ser diagnosticada pelo cultivo do microorganismo, demonstração do agente infeccioso ou seus produtos nos tecidos ou fluidos corporais, detecção de resposta imune específica (LOW; DONACHIE, 1997) e detecção de seqüências genéticas específicas (FARBER; PETERKIN, 1991).

\subsubsection{Métodos convencionais}

Vários meios seletivos têm sido descritos para Listeria spp., principalmente pela maior dificuldade de seu isolamento de amostras contaminadas, como as fezes (LOW; DONACHIE, 1997). As substâncias seletivas e indicadoras variam nas 
diferentes formulações. Dentre as drogas mais utilizadas, destacam-se a acriflavina, glicina anidra, feniletanol, cloreto de lítio, esculina, telurito de potássio e vários antibióticos (FARBER; PETERKIN, 1991).

Para o pré-enriquecimento da amostra, um dos primeiros métodos utilizados foi o enriquecimento a $4^{\circ} \mathrm{C}$. A amostra era diluída em caldo nutriente, mantida a $4^{\circ} \mathrm{C}$, e semeada em meio sólido após 24 horas e semanalmente por até três meses. Em relação a estes caldos, este enriquecimento a frio é inicialmente realizado a fim de se inibir o crescimento de outras bactérias e estimular o da Listeria, podendo-se utilizar meios como caldo triptosado e caldo de enriquecimento seletivo para Listeria - LSEB (ERDOGAN; CRIPPS; MORGAN, 2002). A incorporação de agentes seletivos ao meio líquido reduziu consideravelmente este tempo e hoje utilizam-se caldos de enriquecimento seletivo em duas etapas, como por exemplo o UVM University of Vermont (KANUGANTI et al., 2002) - e Fraser (CHASSEIGNAUX et al., 2002; BELOEIL et al., 2003); em relação ao isolamento a partir de carne suína, tonsilas e fezes o pré-enriquecimento em caldo Fraser é descrito com sucesso por diferentes autores (CHASSEIGNAUX et al., 2001; KANUGANTI et al., 2002).

Entre os meios sólidos, o ágar PALCAM tem sido o mais utilizado na Europa e o meio ágar Oxford nos Estados Unidos (FARBER; PETERKIN, 1991). Os trabalhos visando o isolamento do agente a partir de fezes e carne suína descrevem - PALCAM como uma boa opção. A formulação deste meio inclui ágar base Columbia com $0,05 \%$ de glicose, suplementado com polimixina $B$, acriflavina, cloreto de lítio, ceftazimidina, esculina e manitol e as colônias de Listeria spp. apresentam aspecto verde acinzentado com centro negro (KANUGANTI et al., 2002). Recentemente, um ágar com desempenho superior ao PALCAM no isolamento de Listeria spp. tem sido utilizado. Esta ágar é denominado ALOA (Ágar Listeria acc. de Ottaviani e Agosti - Biolife, Milão, Itália) e é capaz de indicar o crescimento de $L$. monocytogenes e L. ivanovii baseado na sua produção de PIPLC - fosfatidilinositol fosfolipase C específica. Neste meio, todas as listerias têm formação de colônias azuis, mas somente as patogênicas - L. monocytogenes e L. ivanovii - têm a formação de um halo opaco, o que facilita muito sua identificação e propicia o sucesso do isolamento (BAWENS; VERCAMMEN; HERTSENS, 2003; BELOEIL et al., 2003). 


\subsubsection{Métodos alternativos}

Nos últimos anos, vários métodos têm sido pesquisados para agilizar o processo de detecção de L. monocytogenes, dentre os quais: ELISA, soroaglutinação, fixação do complemento, hemaglutinação, inibição da hemaglutinação (LOW; DONACHIE, 1997), citometria de fluxo, hibridização do DNA e reação em cadeia pela polimerase - PCR (FARBER; PETERKIN, 1991). Dentre estes, a PCR tem se destacado devido à grande sensibilidade, rapidez, especificidade e ao potencial de aplicação em larga escala, além de também ser menos provável de ser influenciada por fatores externos que alterariam 0 crescimento e o metabolismo da bactéria, por detectarem diferenças genéticas (BATT, 1997). Diferentes autores descrevem oligonucleotídeos iniciadores, capazes de identificar e diferenciar Listeria spp. e L. monocytogenes através da amplificação de regiões específicas do gene hlyA (hemolisina) ou 16S rRNA (BESSESEN et al., 1990; BORDER et al., 1990, WESLEY et al., 2002) e, mais recentemente, outros capazes de identificar a presença ou não da virulência in vivo do isolado, como o gene Imo2821 (inlJ - LIU et al., 2007).

\subsubsection{Caracterização genotípica}

Os métodos fenotípicos geralmente utilizados para caracterização da $L$ monocytogenes apresentam baixo poder discriminatório e não são adequados para estudos epidemiológicos envolvendo surtos de listeriose ou contaminação de alimentos pelo agente (GIOVANNACCI et al., 1999); o esquema todo leva mais de seis dias para finalizar um resultado, que pode ser variável e levar à reclassificação do isolado após realização de testes genotípicos (AZNAR; ALARCON, 2002). Assim, diferentes métodos genotípicos têm sido aplicados para a identificação e sorotipagem do agente como a PCR (BORDER et al., 1990; BORUCKI; CALL, 2003) e para caracterização epidemiológica desta bactéria, sendo os mais citados a amplificação randômica de DNA polimórfico (RAPD), a análise com enzimas de 
restrição (REA), polimorfismo do comprimento de fragmentos de restrição (RFLP) e a eletroforese em campo pulsado - PFGE (NAKAMA, et al., 1998; GIOVANNACCI et al., 1999; YOSHIDA et al., 1999; CHASSEIGNAUX et al., 2001). Estes métodos têm apresentado bons resultados com especificidade e poder discriminatório variáveis, mas em alguns casos são demorados e exigem equipamentos especiais e alto grau de padronização para obtenção de resultados confiáveis (DE ZOYZA; EFSTRATIOU, 2000).

\subsubsection{Controle e prevenção}

Ao se estabelecer um estudo epidemiológico da Listeria na cadeia alimentar, pode-se desenhar sua trajetória nesta cadeia, possibilitando a descoberta da fonte de contaminação do ambiente e/ou alimentos. Desta forma, uma intervenção é possível a fim de se prevenir a introdução do agente ou então controlar sua multiplicação e disseminação. Se o fator de risco se encontra ainda na criação dos animais, deve-se atentar para este setor, principalmente no que se refere à origem da matéria-prima das rações, bem como na higiene e desinfecção das instalações (BELCEIL et al, 2003). No entanto, se estes fatores apresentam-se já nas plantas de processamento de abatedouros, deve-se implementar programas de sanitização (PETTINATI, 2004), boas práticas de manipulação (BONARDI; BRINDANI; MAGGI, 2002) e a análise de riscos dos pontos críticos de controle - HACCP (FARBER; PETERKIN, 1991). 


\subsubsection{Taxonomia}

A diferenciação da atual $Y$. enterocolitica dos isolados de "Y. enterocolitica like", descritos desde que VanLoghem estabeleceu o gênero Yersinia em 1944 (em homenagem a A. J. Yersin, quem primeiro descreveu o 'bacilo da praga' - Y. pestis) tem sido feita através de técnicas da biologia clássica e molecular (BOTTONE, 1997). Estudos bioquímicos realizados estabeleceram as espécies de Yersinia: $Y$. enterocolitica, Y. fredericksenii, Y. intermedia e Y. kristensenii (BERCOVIER et al., 1980; BRENNER et al., 1980; URSING et al., 1980); Y. mollareii e Y. bercovieri (WAUTERS et al., 1988a); Y. aldovae e Y. rhodei (BERCOVIER et al., 1984); e Y. ruckeri (ALEKSIC et al., 1987). Estas espécies, juntamente com Y. pestis (peste bubônica) e $Y$. pseudotuberculosis (pseudotuberculose), formam o gênero Yersinia, da família Enterobacteriaceae, sendo estas duas últimas e a $Y$. enterocolitica patogênicas para o homem (BOTTONE, 1997).

A Y. enterocolitica é altamente heterogênea e pode ser dividida em vários biosorotipos, sendo alguns associados à doença em humanos: 1B/ O:8; 2/ 0:5, 27; 2 / O:9; 3/O:3 e 4/O:3 (BOTTONE, 1997).

\subsubsection{Características microbiológicas e fenotípicas}

A Y. enterocolitica é um coco-bacilo gram negativo, que mede $1,2 \mu \mathrm{m}$ de comprimento e de 0,5 a $1,0 \mu \mathrm{m}$ de diâmetro, anaeróbio facultativo e oxidase negativo (BOTTONE, 1997). O agente multiplica-se em temperaturas que variam de 0 a $44^{\circ} \mathrm{C}$, sendo de 25 a $28^{\circ} \mathrm{C}$ a temperatura ótima; resiste à temperatura de 
congelamento, o que capacita sua sobrevivência até em alimentos congelados; entretanto, é sensível ao calor, sendo destruído pela pasteurização $\left(71,8^{\circ} \mathrm{C}\right.$ por 30 segundos). Cresce em faixa de $\mathrm{pH}$ de 4 a 10, mas o pH ótimo é de 7,6 (FALCÃO; FALCÃO, 2006). Ela é mais ativa bioquimicamente a $25^{\circ} \mathrm{C}$ do que a $37^{\circ} \mathrm{C}$, o que pode interferir nos resultados de isolamento. Além disso, o plasmídeo de virulência também tem conhecida sensibilidade à temperatura. Assim, um extenso protocolo de caracterização parece intimidar, mas a vasta maioria das não-Y. enterocolitica é efetivamente eliminada com os primeiros passos. A $Y$. enterocolitica fermenta sucrose, xilose e manitol, além de lactose; produz urease e é móvel a $25^{\circ} \mathrm{C}$, pela presença de flagelos peritríquios, mas não a $37^{\circ} \mathrm{C}$ (BOTTONE, 1997). Pode ser classificada em sorogrupos, com base em seus antígenos $\mathrm{O}$ (somáticos) e $\mathrm{H}$ (flagelares), e em biotipos, de acordo com suas propriedades bioquímicas, sendo apenas poucos deles relacionados a doenças em humanos (ASPLUND et al., 1990).

Os isolados devem ser submetidos a um esquema no qual há grande acordo entre bioquímica, sorologia e ecologia das fontes dos isolados: prova de produção de indol, hidrólise de esculina, fermentação de salicina, fermentação de d-xilose, rhamnose, melibiose, trealose e lecitinas. A partir de então são divididas em nove subgrupos: I, II, III (A, B e C), IV, V, VI e VII. O sorogrupo I consiste dos isolados sorotipo $0: 3$, patogênico para humanos. No sorogrupo III A, dentre outros, estão os isolados do sorotipo $0: 5 b$, presentes em casos clínicos de humanos nos Estados Unidos, e O:3 na Europa, Austrália e outros países também em humanos; e o III C inclui somente o sorotipo O:9. Já no sorogrupo IV, estão os isolados patogênicos para humanos do sorotipo 0:8, dos Estados Unidos e Canadá apenas. Nos demais sorogrupos não há isolados patogênicos para humanos (WINBLAD, 1979).

\subsubsection{Mecanismos de virulência}

A $Y$. enterocolitica é adquirida usualmente através de alimentos contaminados; por isso, este microorganismo deve primeiro adaptar seus antígenos de superfície para acomodar-se a um aumento da temperatura (para $37^{\circ} \mathrm{C}$ ). Isto é 
alcançado em parte pela presença de um plasmídeo de virulência (pYV - plasmid for Yersinia virulence) de 64 a 75 kb, que está ausente em isolados avirulentos. Na presença deste plasmídeo várias proteínas externas de membrana são expressadas a $37^{\circ} \mathrm{C}$ mas não a $25^{\circ} \mathrm{C}$; desta forma, ele provê meios para ultrapassar numerosos mecanismos de defesa do hospedeiro e fazer com que a Yersinia se estabeleça no seu nicho ecológico extracelular ou nos macrófagos (BOTTONE, 1997).

A infecção pela $Y$. enterocolitica patogênica é causada pela disseminação do agente na luz intestinal até sua instalação nos enterócitos (gastroenterites) ou linfonodos mesentéricos (linfadenite), podendo alcançar diversas partes do organismo através do sangue. A colonização do trato gastrointestinal dá-se, inicialmente, pela adesão da bactéria ao muco intestinal, sendo o mecanismo exato ainda desconhecido (MANTLE; HUSAR, 1993); entretanto, sabe-se estar relacionado a uma proteína externa de membrana, expressada a $37^{\circ} \mathrm{C}$ pelo plasmídeo, denominada YadA (Yersinia adhesion), que recobre toda a bactéria e confere hidrofobicidade e autoaglutinação, promovendo adesão ao muco, sendo o local preferencial de adesão as células M das placas de Peyer (BOTTONE, 1997). Outros genes cromossomais também fazem parte deste processo: inv, gene de invasão, que codifica outra proteína externa de membrana e que diretamente inicia a penetração por ligação a receptores específicos (integrinas) e ail, gene de adesão e invasão, que codifica um fator que também promove a invasão de células epiteliais (MILLER; FALKOW, 1988). Ao mesmo tempo, a bactéria tem que escapar da fagocitose por leucócitos polimorfonucleares e células mononucleares e, para isso, outras proteínas externas de membranas, as Yops (yersinia outer proteins), são expressadas pelo plasmídeo, conferindo essa resistência à fagocitose (LIAN; HWANG; PAI, 1987). As Yops, além dessa função, também são responsáveis por conferir imunidade, como a YopB que capacita a evasão da defesa imune após a ingestão, por suprimir a produção de uma citocina derivada de macrófago, o fator de necrose tumoral $\alpha$ (TNF- $\alpha$ ), que tem papel central na regulação da imunidade celular e resposta inflamatória a infecção (BEUSCHER et al., 1995), sendo o alvo exato na membrana do macrófago para a YopB ainda desconhecido. Além desses fatores, a $Y$. enterocolitica produz uma enterotoxina termoestável, codificada por um gene cromossomal, conhecida como yst, que está envolvida na diarréia que ocorre na yersiniose. Há também relatos de uma enterotoxina termoestável em $Y$. 
enterocolitica biotipo 1A, a Yst-II ou -b, que é antigenicamente relacionada a Yst-a das $Y$. enterocolitica patogênicas (ROBINS-BROWNE et al., 1993); outros autores relatam este gene como homólogo não específico ou como gene yst inativo, já que não necessariamente produzem toxina in vitro (KWAGA; IVERSEN, 1992).

\subsubsection{Yersiniose humana}

Infecções clínicas humanas ocorrem após a ingestão do microorganismo em alimentos e água contaminados ou por inoculação direta através de transfusão sangüínea, podendo ser de ordem gastrointestinal ou septicêmica (BOTTONE, 1997). A dose infectante ainda não é perfeitamente conhecida, mas deve estar acima de $10^{4}$ UFC (FALCÃO; FALCÃO, 2006).

Ao infectar o trato gastrointestinal, a ocorrência mais freqüente é enterite aguda com febre e inflamação, principalmente em crianças, podendo ocorrer também bacteremia. Já em adultos jovens, há infecção em íleo terminal, com o agente alcançando os linfonodos mesentéricos, devido à sua predileção por células linfóides, mimetizando um quadro de pseudoapendicite (BOTTONE, 1997). A septicemia causada pela $Y$. enterocolitica é mais rara, mas pode ocorrer tanto em indivíduos saudáveis, com excesso de ferro ou imunossuprimidos, ou através de transfusão sangüínea; seu curso clínico pode incluir a formação de microabscessos em fígado e baço, pneumonia, artrite séptica, meningite, osteomielite e endocardite, sendo a letalidade, nestes casos, de 30 a 60\% (FALCÃO; FALCÃO, 2006). Embora a maior parte dos casos de yersiniose se resolva totalmente após o tratamento, em alguns casos pode haver seqüelas auto-imunes associadas com 0 antígeno leucocitário humano HLA-B27, que podem ser artrite, eritema nodoso, glomerulonefrite, miocardite e síndrome de Reiter, principalmente por infecção pela Y. enterocolitica 4/ O:3 (LAITENEN; TUUHEA; AHVONEN, 1972) e distúrbios da tireóide (FALCÃO; FALCÃO, 2006). Além desses, infecções hospitalares por $Y$. enterocolitica também podem ocorrer (RATNAM et al., 1982). Deve-se lembrar que 
outras yersinias como: Y. intermedia e Y. kristensenii também são capazes de causar infecções em raros casos (BOTTONE, 1997).

\subsubsection{Epidemiologia}

A epidemiologia da yersiniose é, em grande parte, ainda desconhecida. Entretanto, há associação de alimentos contaminados, especialmente carne suína, com a ocorrência da doença (BOER; NOUWS, 1991). Evidências indiretas sugerem que a carne suína é uma importante ligação entre o reservatório suíno e a infecção humana, como a correlação entre consumo de carne suína, crua ou mal cozida, e a prevalência da yersiniose, encontrada num estudo de caso-controle realizado por Tauxe et al. (1987).

Muitos dos isolados de $Y$. enterocolitica de casos clínicos pertencem ao biosorotipo 4/ 0:3, o qual é freqüentemente isolado de tonsilas e fezes de suínos abatidos, com grande correlação genética; e a maioria dos relatos mantêm a hipótese de que o suíno é a principal fonte de yersiniose humana (KAPPERUD et al., 1990; FUKUSHIMA et al., 1993; FREDRIKSSON-AHOMAA et al., 2001b). Além de ser encontrado no suíno, este bio-sorotipo também é isolado de cães e gatos (FREDRIKSSON-AHOMAA; STOLLE; KORKEALA, 2006). Embora esta associação seja verdadeira, a $Y$. enterocolitica patogênica é raramente recuperada de alimentos, mas a carne suína tem sido amplamente estudada sendo alta sua detecção em línguas, tonsilas, fígado, coração e rins (FREDRIKSSON-AHOMAA; STOLLE; KORKEALA, 2006). Esta baixa taxa de isolamento pode ocorrer devido a limitada sensibilidade dos métodos de cultura empregados, o que se comprova quando a pesquisa é realizada por PCR (FREDRIKSSON-AHOMAA; KORKEALA, 2003).

Quanto à via de transmissão, a principal é a oro-fecal, por alimentos contaminados, mas também podem ocorrer por transfusão sangüínea. A $Y$. enterocolitica patogênica pode ser transmitida de abatedouros para plantas de processamento de carnes e então para as carnes ou órgãos suínos, provenientes de 
carcaças contaminadas, chegando então aos consumidores. A contaminação cruzada também pode ocorrer direta ou indiretamente via equipamentos, ar e alimentos manipulados nos abatedouros, em açougues e nas cozinhas dos consumidores (FREDRIKSSON-AHOMAA; STOLLE; KORKEALA, 2006).

No Brasil, trabalhos indicam o suíno vivo (MENDONÇA et al., 1995; HOFER; LÁZARO, 1997; LEAL; LEAL; ALMEIDA, 1997) e suínos abatidos (TEODORO, et al., 2006) como portadores e a presença do agente em alimentos (ALBUQUERQUE; CARDOSO, 1999; FALCÃO et al., 2006); entretanto, alguns autores relatam haver diferenças de acordo com a região do país estudada, no isolamento do agente em suínos, em alimentos e em amostras clínicas de humanos (LEAL; LEAL; ALMEIDA, 1997). Além disso, não há estudos a respeito da epidemiologia deste agente na cadeia de produção da carne suína no país.

Os sorotipos mais comumente associados com a yersiniose em humanos são O:3 na Europa e 0:8 e 0:5,27 nos EUA (HARIHARAN et al., 1995), sendo no Brasil já relatado o sorotipo O:3 (MENDONÇA et al., 1995; HOFER; LÁZARO, 1997).

\subsubsection{Yersinia em alimentos}

A $Y$. enterocolitica é um microorganismo ubiqüitário, e a maioria dos isolados obtidos de portadores assintomáticos, alimentos e amostras de ambiente não é patogênico (FREDRIKSSON-AHOMAA; KORKEALA, 2003). Este agente, assim como a L. monocytogenes, é um patógeno transmitido por alimentos, e foi recuperado em cinco de seis surtos ocorridos nos EUA (BOTTONE, 1997).

Isolados patogênicos do agente estão presentes na cavidade oral e intestinos de suínos bem como no ambiente de abatedouros, podendo contaminar produtos cárneos (NESBAKKEN et al., 2003). Por este motivo e devido à sua capacidade de se multiplicar em temperaturas que variam de 1,0 a $44^{\circ} \mathrm{C}$, deve-se despender atenção aos produtos de origem animal, como a carne suína, principalmente àquelas que ficam em geladeira para preservação, mesmo as embaladas a vácuo e aquelas 
já submetidas ao tratamento térmico. Além disso, pode crescer em faixas de $\mathrm{pH}$ que variam de 4,0 a 10 o que pode acontecer no caso de alimentos in natura e processados (BOTTONE, 1997).

\subsubsection{Métodos de detecção}

A presença de $Y$. enterocolitica pode ser diagnosticada num extenso trabalho pelo cultivo do microorganismo, pela deteç̧ão de resposta imune específica e, mais recentemente, pela detecção de seqüências genéticas específicas (BOTTONE, 1997).

\subsubsection{Métodos convencionais}

A fonte do agente pode afetar o método de isolamento, sendo geralmente mais fácil o isolamento de amostras clínicas do que de portadores assintomáticos onde o número de isolados patogênicos é pequeno - alimentos e ambientes - onde o número de microorganismos de flora competidora é muito grande. O crioenriquecimento, por períodos prolongados com plaqueamento direto e semanal, tem gerado bons resultados (FREDRIKSSON-AHOMAA; KORKEALA, 2003); entretanto alguns autores encontraram melhores resultados recuperando isolados com plaqueamento após 14 e 21 dias do crio-enriquecimento, principalmente se há combinação com tratamento com álcalis (KECHAGIA et al., 2007). Entretanto, meios de enriquecimento seletivo (caldo e ágar) têm sido desenvolvidos utilizando-se suplementos e antibióticos, tais como caldo Rappaport modificado (MRB) suplementado com irgasan, ticarcilina e cloreto de potássio, que gera o caldo ITC (WAUTERS et al., 1988b) e caldo soja triptona (TSB) suplementado com polimixina e novobiocina, que gera o caldo TSPN (LANDGRAF; IARIA; FALCÃO, 1993), além dos ágares CIN (cefsulodin-irgasan-novobiocina) e ágar SSDC (Salmonella-Shigella 
deoxycolato-calcium-cloride). Para a caracterização de isolados como $Y$. enterocolitica, algumas provas bioquímicas podem ser indicadas como fermentação de sucrose, rhamnose e melibiose (SCHIEMANN, 1989), assim como ferro de Kligler e uréia de Christensen (DEVENISH; SCHIEMANN, 1981); além desses ainda existe o sistema API 20E para Y. enterocolitica. Após este passo, há a biogrupagem com o esquema proposto por Wauters, Kandolo e Janssens (1987).

\subsubsection{Métodos alternativos}

Nos últimos anos, a PCR também vem sendo utilizada como uma ferramenta eficiente, sendo muito importante na detecção de $Y$. enterocolitica de alimentos. Vários ensaios de PCR são desenvolvidos para detectar $Y$. enterocolitica pYV positiva, em amostras clínicas, de alimentos e ambientes; muitos destes métodos utilizam primers que têm como alvo os genes virF e yadA, localizados no plasmídeo de virulência, além de outras Yops. Entretanto, como há possibilidade de perda de plasmídeo durante os métodos de cultivo e estocagem dos isolados, reações de PCR que têm como alvo genes cromossomais também são utilizadas, sendo eles: inv, ail e yst (FREDRIKSSON-AHOMAA; KORKEALA, 2003). Por isso, muitos autores desenvolvem reações na forma de multiplex, procurando detectar genes tanto plasmidiais quanto cromossomais ligados à virulência do agente, como o descrito por Weynants et al. (1996).

\subsubsection{Caracterização genotípica}

Os métodos fenotípicos geralmente utilizados para caracterização da $Y$. enterocolitica apresentam baixo poder discriminatório e não são adequados para estudos epidemiológicos envolvendo surtos de yersiniose ou contaminação de alimentos pelo agente, pois os isolados clínicos de humanos não podem ser diferenciados dos isolados de outras origens (LAMBERTZ; DANIELSSON-THAM, 
2005). Sendo assim, diferentes métodos genotípicos têm sido aplicados para caracterização epidemiológica, sendo os mais citados PCR (repetitive element PCR - rep-PCR; enterobacterial repetitive intergenic consensus - ERIC e amplificação randômica de DNA polimórfico - RAPD), a análise com enzimas de restrição (REA), polimorfismo dos comprimentos de fragmentos amplificados (AFLP), a ribotipagem e a eletroforese em campo pulsado - PFGE (LAMBERTZ; DANIELSSON-THAM, 2005; FREDRIKSSON-AHOMAA; STOLLE; KORKEALA, 2006). Estes métodos têm apresentado bons resultados com especificidade e poder discriminatório variáveis, mas, em alguns casos, são demorados e exigem equipamentos especiais e alto grau de padronização para obtenção de resultados confiáveis (DE ZOYZA; EFSTRATIOU, 2000).

\subsubsection{Controle e prevenção}

Ao se estabelecer um estudo epidemiológico da Yersinia na cadeia alimentar, pode-se desenhar sua trajetória nesta cadeia, possibilitando a descoberta da fonte de contaminação do ambiente e/ou alimentos. Se este fato pode ser obtido, uma intervenção deve ser realizada a fim de se prevenir a introdução do agente ou então controlar sua multiplicação e disseminação. Se o fator de risco se encontra ainda na criação dos animais, deve-se atentar para este setor, principalmente no que se refere à origem dos animais ou à mistura deles em um mesmo local (NESBAKKEN et al., 2006), bem como na higiene e desinfecção das instalações e na alimentação dos animais (SKJERVE et al., 1998). No entanto, se estes fatores apresentam-se também nos abatedouros, nas plantas de processamento de carne e açougues, deve-se implementar programas de sanitização, boas práticas de manipulação e a análise de riscos dos pontos críticos de controle - HACCP (ANDERSEN, 1988; KAPPERUD, 1991). 
OBJETIVOS 


\section{OBJETIVOS}

- Avaliar a presença de Listeria monocytogenes e Yersinia enterocolitica em línguas e tonsilas de suínos em abatedouros, bem como em carnes suína provenientes de carcaças dos mesmos abatedouros já nos mercados, e em seus ambientes, no Estado de São Paulo;

- Caracterizar fenotípica e genotípica os isolados;

- Comparar os isolados de diferentes origens pela PFGE, entre si e com isolados de casos clínicos em humanos, obtendo-se possíveis pontos para controle da disseminação dos agentes. 
MATERIAL E MÉTODO 


\section{MATERIAL E MÉTODO}

\subsection{AMOSTRAS}

Foram analisadas um total de 792 amostras, incluindo 480 suabes de língua e tonsilas, 120 suabes de ambientes dos abatedouros, 120 cortes de carnes suína e 72 suabes de ambientes de mercados, sendo 66 amostras por mês de coleta, num total de 12 coletas realizadas, de maio de 2007 a abril de 2008, sempre nos mesmos estabelecimentos.

Além desses, dez isolados de casos clínicos de humanos de $L$. monocytogenes e dois de $Y$. enterocolitica foram cedidos pelo Doutor Ernesto Hofer, da Fundação Instituto Oswaldo Cruz (Rio de Janeiro); e outros dez isolados de casos clínicos de humanos de $Y$. enterocolitica foram cedidos pela Professora Doutora Juliana Pfrimer Falcão, da Faculdade de Ciências Farmacêuticas de Ribeirão Preto da Universidade de São Paulo, todos para avaliação pela eletroforese em campo pulsado (PFGE).

Como padrões, na PCR e no controle de qualidade dos meios de cultura, foram utilizadas as amostras de Listeria monocytogenes ATCC 19111 (1/2a), ATCC 19115 (4b), L. ivanovii ATCC 19119, L. innocua CIP 12612, L. seeligeri CIP 8493, Yersinia enterocolitica O:3 MyO - SW/897/63 - biotipo 4, Y. enterocolitica 0:8 P311 - WF - Albany USA - biotipo 1B, Y. enterocolitica 0:9 - My79 - Nilhén Suécia - biotipo 2, Y. pseudotuberculosis - IAL1791, Y. frederiksenii - CIP8029 e Y. kristensenii - CIP9993, todas fornecidas pelo Doutor Ernesto Hofer.

\subsection{COLHEITA DAS AMOSTRAS}

Mensalmente, foram coletados 20 suabes de língua e tonsilas e cinco suabes de ambientes, de cada linha, em dois abatedouros do Estado de São Paulo. Além 
dessas, também foram coletadas amostras em dois mercados, sendo cinco carnes e três suabes de ambientes, em cada um.

Os suabes, que consistiam em esponjas esterilizadas medindo $10 \mathrm{~cm}$ x 5,0 $\mathrm{cm}$, eram previamente embebidos em meio Letheen (Difco), para redução da atividade de desinfetantes e, após a coleta, mantidos em embalagem plástica estéril sob refrigeração até o momento do processamento.

As carnes obtidas nos mercados eram de carcaças oriundas dos abatedouros visitados e foram acondicionadas em bolsas plásticas estéreis e mantidas sob refrigeração até o processamento.

\subsection{EXAME BACTERIOLÓGICO}

Ao chegar ao Laboratório de Sanidade Suína e Virologia - VPS - FMVZ USP, os suabes foram divididos em dois fragmentos $\mathrm{e}$ as carnes foram fragmentadas e separadas em duas porções de $25 \mathrm{~g}$, todos com o auxílio de pinças e tesouras estéreis, para a pesquisa dos dois microorganismos.

\subsubsection{Listeria monocytogenes}

4.3.1.1 Suabes de língua e tonsilas e de ambientes

Os suabes de língua e tonsilas e de ambientes foram analisados de acordo com o descrito por Belœil et al. (2003), com modificações (Figura 1). Em cada bolsa plástica contendo o fragmento do suabe foram adicionados $112,5 \mathrm{ml}$ de caldo Triptose (Difco). A bolsa foi agitada em Stomacher por 30 segundos, em velocidade normal, e mantida em geladeira por 2 a 4 dias. Deste caldo, $100 \mu \mathrm{l}$ foram adicionados a $10 \mathrm{ml}$ de caldo Fraser Meio (Oxoid), incubando-se a $30^{\circ} \mathrm{C}$ por 24 horas. Após este período foram adicionados $100 \mu \mathrm{l}$ do caldo Fraser Meio a $10 \mathrm{ml}$ de 
caldo Fraser Inteiro (Oxoid) sendo este incubado a $30^{\circ} \mathrm{C}$ por 24 a 48 horas. Deste caldo, uma alçada foi estriada em placas contendo o meio ALOA (Biolife) e estas foram incubadas a $37^{\circ} \mathrm{C}$ por 24 horas. Foram selecionadas a partir do meio ALOA colônias azuis, com halo opaco (indicativas de L. monocytogenes), que foram semeadas em meio de motilidade (Difco) e mantidas à temperatura ambiente $\left(25^{\circ} \mathrm{C}\right)$, por 3 a 4 dias. Os isolados que apresentaram motilidade característica de Listeria spp foram semeados em placas de ágar soja triptona - TSA (Oxoid) com 0,6\% extrato de levedura a $30^{\circ} \mathrm{C}$, por 24 horas. Este ágar foi observado em luz oblíqua e as colônias azuis, características de Listeria spp. foram transferidas para 2,0 $\mathrm{ml}$ de caldo infusão cérebro coração - BHI (Difco) e incubadas a $37^{\circ} \mathrm{C}$, por 24 horas. Os isolados foram então submetidos à extração de DNA e semeados, em duplicata, em ágar semi-sólido, para envio para sorotipagem e estoque à temperatura ambiente, para posteriormente serem estocados em freezer $-80^{\circ} \mathrm{C}$.

\subsubsection{Carnes}

Uma porção de $25 \mathrm{~g}$ de cada carne, sem gordura, foi cortada, com pinça e tesoura estéreis, em pequenos fragmentos e acondicionados em bolsa plástica estéril juntamente com $225 \mathrm{ml}$ de caldo Triptose. As bolsas foram agitadas em Stomacher por 1 minuto, em velocidade normal, e mantidas em geladeira por 2 a 4 dias. A partir deste ponto, o procedimento foi idêntico ao realizado para os suabes. 


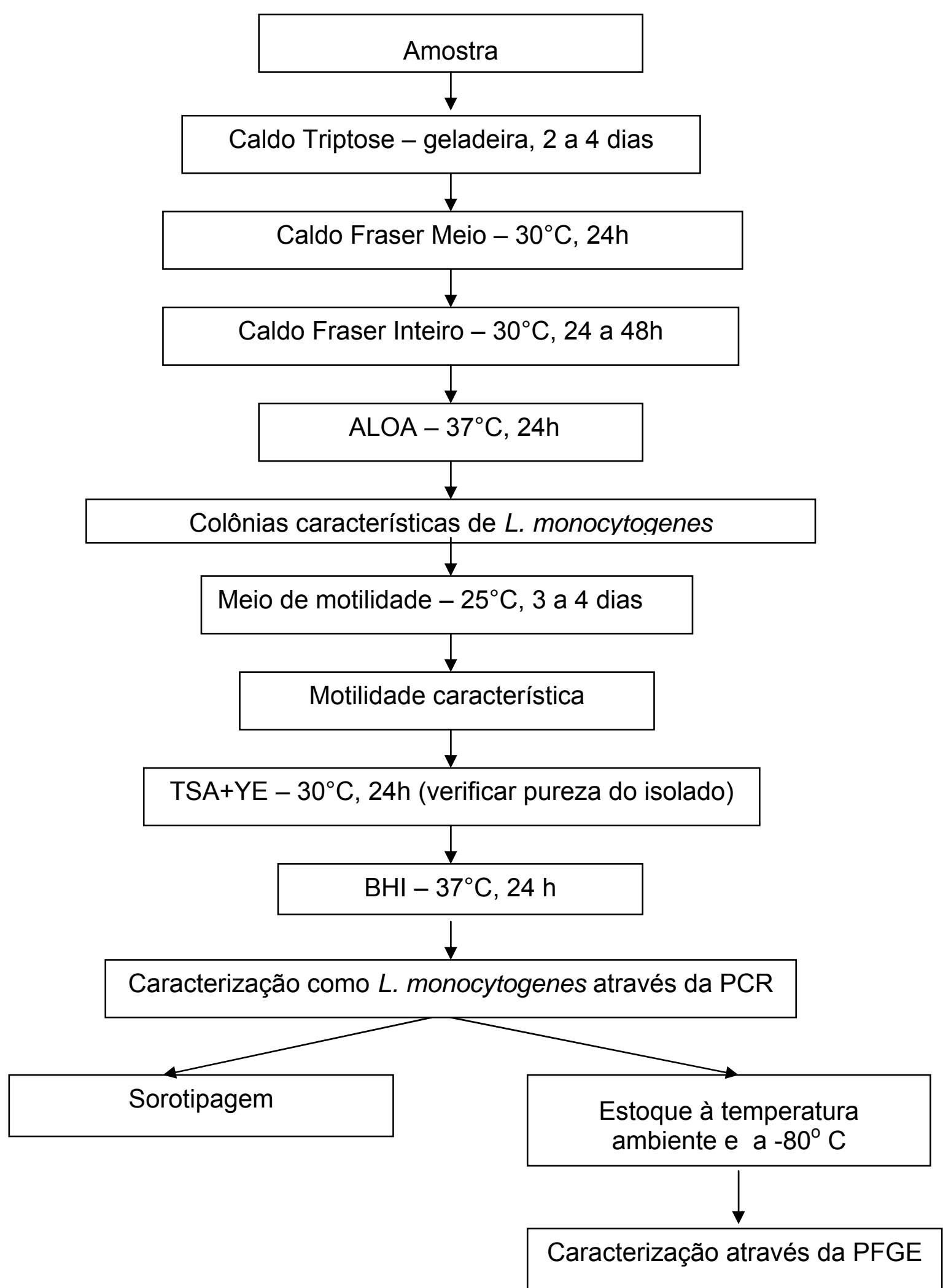

Figura 1 - Organograma de execução do isolamento bacteriano e posterior caracterização dos isolados de Listeria monocytogenes através da PCR e PFGE 


\subsubsection{Yersinia enterocolitica}

4.3.2.1 Suabes de língua e tonsilas e de ambientes

Os suabes de língua e tonsilas e de ambientes foram analisados segundo o protocolo descrito na figura 2. Em cada bolsa plástica contendo o fragmento do suabe foram adicionados 112,5 $\mathrm{ml}$ de caldo PSSB - PBS (LGC Biotecnologia) + peptona (Difco) + sorbitol (Difco) + sais de bile número 3 (Difco). A bolsa foi agitada em Stomacher por 30 segundos, em velocidade normal, e mantida em geladeira por 10 a 12 dias. Deste caldo, com o uso de pipetas estéreis, $100 \mu$ foram adicionados a $1,0 \mathrm{ml}$ de uma solução de $0,5 \%$ de $\mathrm{KOH}$ em solução salina $0,5 \%$, em microtubos estéreis, para inibição da flora contaminante, agitados em vórtex por 10 segundos, e imediatamente semeados: uma alçada em ágar Mac Conkey (Difco) e uma alçada em ágar CIN (cefsulodin, irgasan e novobiocina - Difco) incubando-os a $30^{\circ} \mathrm{C}$ por 24 horas. Após este período, foram selecionadas até cinco colônias com morfologia sugestiva de Yersinia spp. de cada um dos ágares (pequenas, sem cor ou rosa pálido - MacConkey; e pequenas com centro profundo vermelho e bordas sem cor "red bull's eye" - CIN). As colônias foram semeadas em caldo BHI e incubadas a $28^{\circ} \mathrm{C}$ por 24 horas. A partir deste caldo, foi realizada a série bioquímica básica para identificação presuntiva de Yersinia enterocolitica em ágar citrato (Difco), uréia de Christensen (Difco) e ágar ferro de Kligler - KIA (Difco). Os isolados que apresentaram bioquímica sugestiva foram repicados em ágar Mac Conkey ou CIN, a partir do KIA, para verificar sua pureza, sendo então novamente semeados em caldo $\mathrm{BHI}$. Deste caldo, os isolados foram submetidos à extração de DNA e semeados, em duplicata, em ágar semi-sólido, para envio para bio-sorotipagem e estoque à temperatura ambiente, para posteriormente serem estocados em freezer $-80^{\circ} \mathrm{C}$. 


\subsubsection{Carnes}

Uma porção de $25 \mathrm{~g}$ de cada carne, sem gordura, foi cortada em pequenos fragmentos acondicionados em bolsa plástica estéril juntamente com 225 $\mathrm{ml}$ de caldo PSSB. As bolsas foram agitadas em Stomacher por 1 minuto, em velocidade normal, e mantidas em geladeira por 10 a 12 dias. A partir deste ponto o procedimento é igual ao realizado para os suabes. 


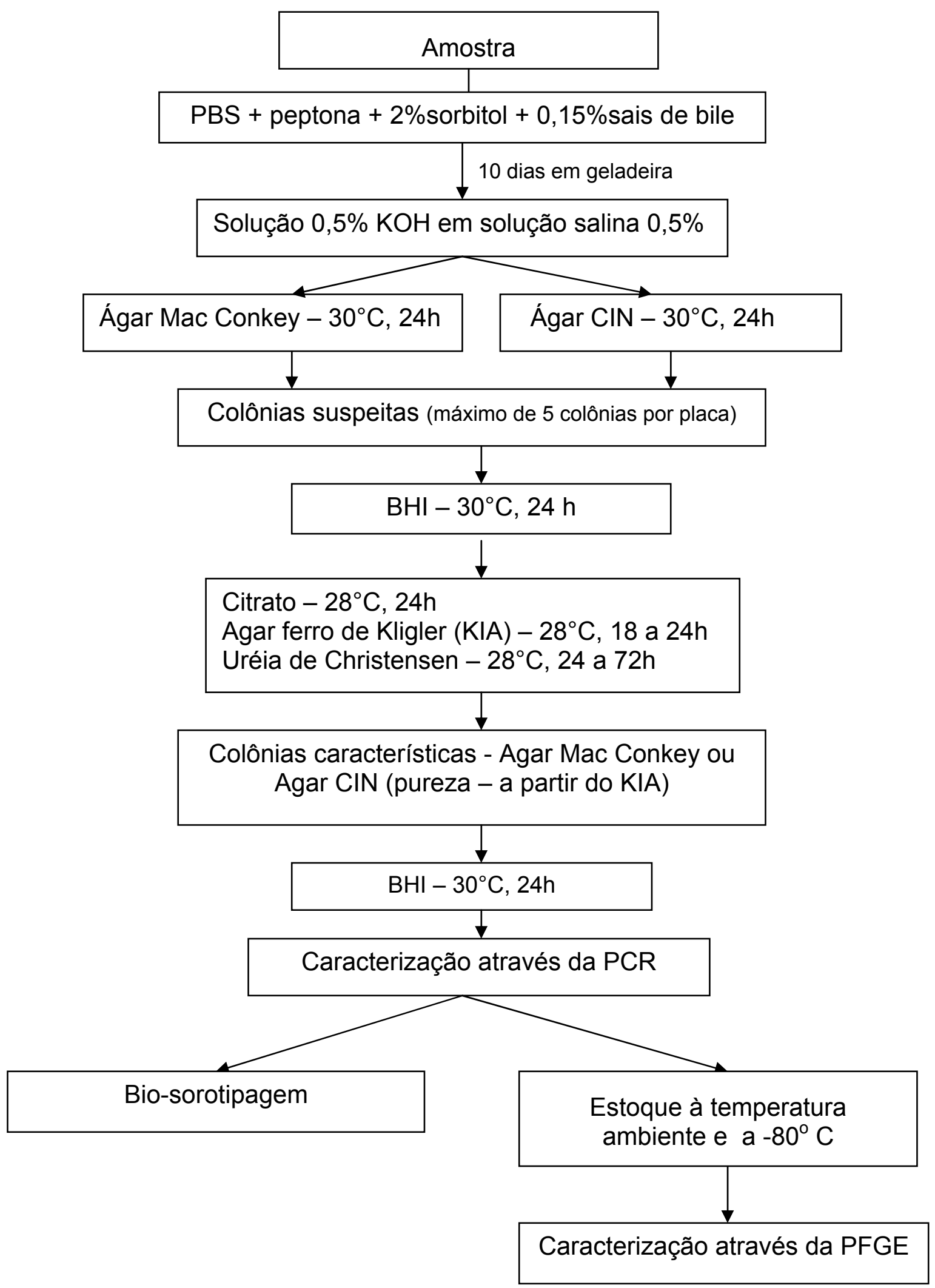

Figura 2 - Organograma de execução do isolamento bacteriano e posterior caracterização dos isolados de Yersinia enterocolitica através da PCR e PFGE 


\subsection{DETERMINAÇÃO DE SOROTIPOS DOS ISOLADOS}

Os isolados foram enviados ao Departamento de Bacteriologia da Fundação Instituto Oswaldo Cruz (Rio de Janeiro) para caracterização fenotípica de Listeria spp. e Yersinia spp.

\subsection{REAÇÃO EM CADEIA PELA POLIMERASE}

\subsubsection{Extração de DNA}

Os isolados selecionados foram semeados em caldo $\mathrm{BHI}$ e incubados em temperatura adequada para cada gênero bacteriano por $24 \mathrm{~h}$. Uma alíquota de 1,0 $\mathrm{ml}$ do caldo foi colocada em um microtubo de $1,5 \mathrm{ml}$; os microtubos foram centrifugados a $12000 \mathrm{~g}$ por 2 minutos e o pélete obtido foi submetido à extração de DNA. Os cultivos bacterianos suspeitos de Listeria monocytogenes, foram incubados com uma solução de proteinase $\mathrm{K}(20 \mathrm{mg} / \mathrm{ml})$ e lisozima $(100 \mathrm{mg} / \mathrm{ml})$ a $37^{\circ} \mathrm{C}$, por 1 hora. A partir deste lisado, no caso da Listeria monocytogenes, e do pélete dos isolados suspeitos de Yersinia enterocolitica, o DNA bacteriano foi purificado pela extração baseada nas propriedades de lise e inativação de nucleases do isotiocianato de guanidina, junto às propriedades das partículas de terra diatomácea em ligar-se ao DNA ou RNA. Este método para purificação de ácidos nucléicos foi descrito por Boom, Sol e Salimans (1990). 


\subsubsection{Amplificação do DNA (PCR)}

\subsubsection{Listeria monocytogenes}

A PCR foi realizada utilizando-se $5 \mu$ do DNA bacteriano, 4,0 mM de $\mathrm{MgCl}_{2}$, $200 \mu \mathrm{M}$ de cada deoxirribonucleotídeo trifosfato, 50 pmoles dos primers específicos para L. monocytogenes (BORDER et al., 1990 - Quadro 1), 1.0 U de Taq DNA polimerase, 1 X tampão de PCR e água até o volume final de $25 \mu \mathrm{l}$. A reação foi submetida à desnaturação inicial a $94^{\circ} \mathrm{C}$ por 4 minutos, seguido por 35 ciclos de desnaturação a $94^{\circ} \mathrm{C}$ por 1,5 minuto, anelamento de $50^{\circ} \mathrm{C}$ por 1,5 minuto e extensão de $72^{\circ} \mathrm{C}$ por 2 minutos, finalizando com extensão a $72^{\circ} \mathrm{C}$ por 5 minutos.

\begin{tabular}{|l|l|l|l|c|}
\hline Alvo & Gene & Nome & Seqüência $\left(5^{\prime} \mathbf{- 3}^{\prime}\right.$ ) & Amplicon $(\mathbf{p b})$ \\
\hline $\begin{array}{l}\text { Listeria } \\
\text { monocytogenes }\end{array}$ & hlyA & $\begin{array}{l}\text { Lis1 } \\
\text { Lis2 }\end{array}$ & $\begin{array}{l}\text { GCA TCT GCA TTC AAT AAA GA } \\
\text { TGT CAC TGC ATC TCC GTG GT }\end{array}$ & 174 \\
\hline
\end{tabular}

Quadro 1 - Oligonucleotídeos utilizados para detecção de Listeria monocytogenes

\subsubsection{Yersinia enterocolitica}

Para Y. enterocolitica foi utilizada uma reação na forma de multiplex conforme descrito por Lambertz e Danielsson-Tham (2005), com $5 \mu$ do DNA bacteriano, 2,0 $\mathrm{mM}$ de $\mathrm{MgCl}_{2}, 200 \mu \mathrm{M}$ de cada deoxirribonucleotídeo trifosfato, 10 pmoles dos primers ail9a e ail10a, 10 pmoles dos primers Pr2a e Pr2c, 15 pmoles dos primers virF11A e virF12A, 20 pmoles dos primers rfbCa e rfbCb (Quadro 2), $1.0 \mathrm{U}$ de Taq DNA polimerase, $1 X$ tampão de PCR e água até o volume final de $25 \mu \mathrm{l}$. A reação foi submetida à desnaturação inicial a $94^{\circ} \mathrm{C}$ por 3 minutos, seguido por 30 ciclos de desnaturação a $94^{\circ} \mathrm{C}$ por 30 segundos, anelamento de $60^{\circ} \mathrm{C}$ por 1 minuto e extensão de $72^{\circ} \mathrm{C}$ por 1 minuto, finalizando com extensão a $72^{\circ} \mathrm{C}$ por 5 minutos. 


\begin{tabular}{|l|l|l|c|}
\hline Gene $^{*}$ & Nome & Seqüência $\left(\mathbf{5}^{\prime} \mathbf{- 3}^{\prime} \mathbf{)}\right.$ & Amplicon $(\mathbf{p b})$ \\
\hline ail & $\begin{array}{l}\text { 9A } \\
10 A\end{array}$ & $\begin{array}{l}\text { GTT TAT CAA TTG CGT CTG TTA ATG TGT ACG } \\
\text { CTA TCG AGT TTG GAG TAT TCA TAT GAA GCG }\end{array}$ & 454 \\
\hline virF & $\begin{array}{l}11 \mathrm{~A} \\
12 \mathrm{~A}\end{array}$ & $\begin{array}{l}\text { AAG GTT GTT GAG CAT TCA CAA GAT GG } \\
\text { TTT GAG TGA AAT AAG ACT GAC TCG AGAACC }\end{array}$ & 700 \\
\hline yst & $\begin{array}{l}\text { Pr2a } \\
\text { Pr2c }\end{array}$ & $\begin{array}{l}\text { AAT GCT GTC TTC ATT TGG AGC } \\
\text { ATC CCA ATC ACT ACT GAC TTC }\end{array}$ & 145 \\
\hline$r f b C$ & $\begin{array}{l}\text { rfbCa } \\
\text { rfbCb }\end{array}$ & $\begin{array}{l}\text { CGC ATC TGG GAC ACT AAT TCG } \\
\text { CCA CGA ATT CCA TCA AAA CCA CC }\end{array}$ & 405 \\
\hline
\end{tabular}

*ail - gene cromossomal de adesão e invasão, virF - plasmídeo de virulência, yst - enterotoxina termoestável, rfbC - região específica para o sorotipo 0:3.

Quadro 2 - Oligonucleotídeos utilizados para caracterização de Yersinia enterocolitica

\subsubsection{Detecção do produto de amplificação (amplicon)}

A detecção dos produtos de amplificação foi realizada através da eletroforese em gel de agarose (Invitrogen) 1,5\% para L. monocytogenes, e agarose 1000 (Invitrogen) - para melhor separação dos fragmentos do multiplex realizado também a 1,5\%, para a reação de caracterização de $Y$. enterocolitica, utilizando-se tampão TBE 0,5 X (0,04 M tris-borato, 0,001 M de EDTA, $\mathrm{pH} 8,0)$. Os fragmentos amplificados foram visualizadas no sistema de fotodocumentação ImageMaster ${ }^{\circledR}$ (Amershan Biosciences) por meio do uso do corante BlueGreen ${ }^{\circledR}$ (LGC Biotecnologia). Os fragmentos foram identificados com base na utilização de marcador de pares de base 100 bp DNA Ladder (LGC Biotecnologia).

\subsection{ELETROFORESE EM CAMPO PULSADO (PFGE)}

Uma alíquota de $6,0 \mathrm{ml}$ do cultivo bacteriano foi centrifugada a $4000 \mathrm{rpm}$ por 5 minutos e o pélete lavado com solução Pett IV $(1 \mathrm{M} \mathrm{NaCl}, 10 \mathrm{mM}$ Tris pH $8,10 \mathrm{mM}$ EDTA), posteriormente centrifugada como a alíquota. Este novo pélete foi ressuspendido em $500 \mu \mathrm{l}$ da mesma solução e então misturado com igual volume de 
agarose de baixo ponto de fusão (BioRad Laboratories) a 2,0\% e, após homogeneização, transferidas para moldes plásticos. Os plugs (blocos) de agarose resultantes, contendo a amostra, foram submetidos a um processo de lise in situ com uma lavagem por 2 horas com solução de lise $(1 \mathrm{M} \mathrm{NaCl}, 10 \mathrm{mM}$ Tris pH 8 , 200mM EDTA, 0,5\% Na-laurylsarkosine sodium salt, 0,2\% deoxycholic acid sodium salt, $1 \mathrm{mg}$ lisozima/ ml) a $37^{\circ} \mathrm{C}$, e após submetidos à desproteinização em solução (0,5 M EDTA, pH 8,0, 1\% Na-laurylsarkosine sodium salt, $20 \mathrm{mg}$ de proteinase $\mathrm{K} / \mathrm{ml}$ ) a $56^{\circ} \mathrm{C}$ overnight. Os plugs foram então primeiramente lavados com água ultra pura e depois com um tampão de TE (10 mM Tris, 1 mM EDTA) e PMSF (1 mM), por duas vezes. Após, foram novamente lavados com água ultra pura para inativar o PMSF e, por fim, mais duas vezes com tampão TE. Os plugs foram estocados em $900 \mu \mathrm{l}$ tampão TE até o momento da eletroforese.

Uma fração do plug foi submetida à digestão com a enzima de restrição (Apal - $40 \mathrm{U}$, por 20 horas - para Listeria monocytogenes, e Notl - $6 \mathrm{U}$, por 4 horas - para Yersinia enterocolitica) e posteriormente adicionada ao gel de agarose 1\% (BioRad Laboratories). A eletroforese foi conduzida num período de 20 horas a $6 \mathrm{~V} / \mathrm{cm}$, ângulo fixo de $120^{\circ}$, com pulso inicial de 2,0 e final de 20 segundos para $L$. monocytogenes, e com pulso inicial de 1,0 e final de 18 segundos para $Y$. enterocolitica, em tampão TBE $0,5 \times$ mantido a $14^{\circ} \mathrm{C}$, utilizando o sistema de eletroforese CHEF DR III Chiller System (Bio-Rad).

\subsubsection{Análise estatística}

Para análise estatística dos fragmentos obtidos através da PFGE serão utilizados os programas GelWorks 1D Advanced - UVP, versão 4.01 e GelWorks 1D Database versão 1.12 - UVP Bioimaging Systems, Upland, CA. Os perfis serão agrupados segundo coeficiente de Dice e demonstrados graficamente em dendrogramas. 
RESULTADOS 


\section{RESULTADOS}

\subsection{LISTERIA MONOCYTOGENES}

Um total de 391 colônias suspeitas de L. monocytogenes através do exame bacteriológico foram enviadas para sorotipagem, dentre as quais 370 foram confirmadas através da PCR para o gênero e espécie L. monocytogenes. Dessas apenas 348 tiveram esta classificação confirmada através da sorotipagem e estão dispostas nas tabelas 1 e 2, segundo seu local de isolamento, e na tabela 3, conforme sorotipagem. Os 22 isolados restantes foram caracterizados através da sorotipagem como L. innocua não tipável, achado a ser investigado em pesquisa posterior.

Os 21 isolados que não foram identificados como $L$. monocytogenes apresentaram os seguintes resultados de sorotipagem: 6 isolados L. innocua $6 a, 3$ isolados $L$. innocua $6 \mathrm{~b}, 2$ isolados $L$. innocua $4 \mathrm{ab}, 5$ isolados $L$. welshimeri e 1 isolado $L$. seeligeri; os quatro demais isolados foram negativos inclusive para 0 gênero Listeria (cocos gram-positivos). 
Tabela 1 - Distribuição mensal de isolamento de Listeria monocytogenes em línguas e tonsilas de carcaças suínas e em ambientes de dois abatedouros do Estado de São Paulo

\begin{tabular}{|c|c|c|c|c|c|c|c|c|c|c|c|c|c|}
\hline \multirow{2}{*}{\multicolumn{2}{|c|}{$\begin{array}{c}\text { Tipo de amostra } \\
\text { (número de amostras/coleta) }\end{array}$}} & \multicolumn{12}{|c|}{ Abatedouro 1} \\
\hline & & Maio & Junho & Julho & Agosto & Setembro & Outubro & Novembro & Dezembro & Janeiro & Fevereiro & Março & Abril \\
\hline \multicolumn{2}{|c|}{ Língua+tonsilas (20) } & 0 & 0 & 0 & 0 & 0 & 0 & 0 & 0 & $16(2)$ & 0 & 0 & $12(2)$ \\
\hline \multirow{5}{*}{ Ambientes } & Chão $A^{*}{ }^{*}(1)$ & 0 & 0 & 0 & 0 & 0 & 0 & 9 & 8 & 6 & 1 & 5 & 0 \\
\hline & Parede AB (1) & 0 & 0 & 0 & 0 & 0 & 0 & 0 & 0 & 2 & 0 & 0 & 0 \\
\hline & Mesa AB (1) & 0 & 0 & 0 & 10 & 0 & 0 & 7 & 5 & 0 & 0 & 0 & 0 \\
\hline & Chão CF** (1) & 0 & 0 & 1 & 0 & 0 & 0 & 9 & 10 & 7 & 8 & 0 & 0 \\
\hline & Parede CF (1) & 0 & 0 & 0 & 10 & 0 & 0 & 0 & 0 & 0 & 9 & 0 & 7 \\
\hline
\end{tabular}

\begin{tabular}{|c|c|c|c|c|c|c|c|c|c|c|c|c|c|}
\hline \multirow{2}{*}{\multicolumn{2}{|c|}{$\begin{array}{c}\text { Tipo de amostra } \\
\text { (número de amostras/coleta) }\end{array}$}} & \multicolumn{12}{|c|}{ Abatedouro 2} \\
\hline & & Maio & Junho & Julho & Agosto & Setembro & Outubro & Novembro & Dezembro & Janeiro & Fevereiro & Março & Abri \\
\hline \multicolumn{2}{|c|}{ Língua+tonsilas (20) } & 0 & 0 & 0 & 0 & 0 & 0 & 0 & 0 & 0 & 0 & 0 & 0 \\
\hline \multirow{5}{*}{ Ambientes } & Chão $A B^{*}(1)$ & 0 & 0 & 0 & 3 & 14 & 0 & 10 & 10 & 1 & 9 & 3 & 0 \\
\hline & Parede AB (1) & 0 & 0 & 0 & 0 & 0 & 0 & 0 & 0 & 0 & 0 & 0 & 0 \\
\hline & Mesa AB (1) & 0 & 6 & 0 & 0 & 0 & 0 & 0 & 3 & 0 & 0 & 0 & 0 \\
\hline & Chão CF** (1) & 0 & 0 & 0 & 2 & 0 & 0 & 0 & 0 & 0 & 0 & 0 & 0 \\
\hline & Parede CF (1) & 0 & 0 & 0 & 0 & 0 & 0 & 0 & 0 & 0 & 0 & 0 & 0 \\
\hline
\end{tabular}

${ }^{*} \mathrm{AB}$ : sala de abate; ${ }^{\star *} \mathrm{CF}$ : câmara fria. 
Tabela 2 - Distribuição mensal de isolamento de Listeria monocytogenes em carne suína e ambientes de dois mercados do Estado de São Paulo

\begin{tabular}{|c|c|c|c|c|c|c|c|c|c|c|c|c|c|}
\hline \multirow{2}{*}{\multicolumn{2}{|c|}{$\begin{array}{c}\text { Tipo de amostra } \\
\text { (número de amostras/coleta) }\end{array}$}} & \multicolumn{12}{|c|}{ Mercado 1} \\
\hline & & Maio & Junho & Julho & Agosto & Setembro & Outubro & Novembro & Dezembro & Janeiro $^{a}$ & Fevereiro $^{b}$ & Março $^{b}$ & Abril $^{6}$ \\
\hline \multicolumn{2}{|c|}{ Carnes (5) } & $18(1)$ & 0 & 0 & 0 & 0 & 0 & 0 & $7(1)$ & 0 & 0 & 0 & 0 \\
\hline \multirow{3}{*}{ Ambientes } & Chão (1) & 0 & 7 & 9 & 0 & 5 & 10 & 0 & 9 & 0 & 0 & 2 & 0 \\
\hline & Parede (1) & 0 & 0 & 0 & 0 & 0 & 0 & 0 & 0 & 0 & 0 & 0 & 0 \\
\hline & Mesa (1) & 0 & 0 & 0 & 0 & 0 & 0 & 0 & 0 & 0 & 0 & 6 & 0 \\
\hline
\end{tabular}

\begin{tabular}{|c|c|c|c|c|c|c|c|c|c|c|c|c|c|}
\hline \multirow{2}{*}{\multicolumn{2}{|c|}{$\begin{array}{c}\text { Tipo de amostra } \\
\text { (número de amostras/coleta) }\end{array}$}} & \multicolumn{12}{|c|}{ Mercado 2} \\
\hline & & Maio & Junho & Julho & Agosto & Setembro & Outubro & Novembro & Dezembro & Janeiro & Fevereiro & Março & Abril \\
\hline \multicolumn{2}{|c|}{ Carnes (5) } & 0 & 0 & 0 & 0 & 0 & 0 & 10(1) & 0 & 1(1) & 0 & $7(1)$ & 0 \\
\hline \multirow{3}{*}{ Ambientes } & Chão (1) & 0 & 0 & 0 & 0 & 11 & 9 & 0 & 0 & 0 & 0 & 0 & 0 \\
\hline & Parede (1) & 0 & 0 & 0 & 0 & 0 & 0 & 0 & 0 & 0 & 0 & 0 & 0 \\
\hline & Mesa (1) & 8 & 7 & 0 & 0 & 0 & 0 & 10 & 0 & 0 & 9 & 0 & 0 \\
\hline
\end{tabular}

${ }^{a}$ mercado não recebeu carne do abatedouro $1 ;{ }^{b}$ outro mercado - carne recebida do abatedouro 1, mas em novos ambientes. 
Tabela 3 - Sorotipos dos isolados de Listeria monocytogenes (número de colônias)

\begin{tabular}{lccccc}
\hline Local & Lm $\mathbf{1 / 2 a}$ & $\mathbf{L m} \mathbf{1 / 2 b}$ & $\mathbf{L m} \mathbf{1 / 2 c}$ & $\mathbf{L m ~ 4 b}$ & Total \\
\hline Abatedouro 1 & 1 & 6 & 134 & 1 & 142 \\
Mercado 1 & 0 & 7 & 22 & 44 & 73 \\
Abatedouro 2 & 1 & 17 & 38 & 5 & 61 \\
Mercado 2 & 6 & 8 & 18 & 40 & 72 \\
\hline Total & 8 & 38 & 212 & 90 & 348 \\
\hline
\end{tabular}

Das 120 amostras de ambientes de abatedouros e 72 de ambientes de mercados coletadas, $22,50 \%(27 / 120)$ e 18,05\% (13/72) amostras, respectivamente, foram positivas para $\mathrm{O}$ isolamento de L. monocytogenes. $\mathrm{O}$ abatedouro 1 , de menor capacidade de abates diários (50 animais abatidos por hora), apresentou 28,33\% $(17 / 60)$ de seus ambientes analisados positivos para o agente; já o abatedouro 2 , de alta capacidade de abate (200 animais abatidos por hora), apresentou uma menor porcentagem de positivos, 16,66\% (10/60) amostras. Em relação aos mercados 1 e 2, obteve-se $19,44 \%(7 / 36)$ e $16,66 \%$ (6/36) amostras positivas para L. monocytogenes, respectivamente.

Quanto às amostras representativas dos animais, apenas 1,66\% (4/480) das amostras de língua e tonsilas, do abatedouro 1, apresentaram isolamento positivo para L. monocytogenes; e 4,16\% (5/120) das amostras de carne, de ambos os mercados, estavam contaminadas, sendo 3,33\% (2/60) referente ao mercado 1 e 5,0\% (3/60) referente ao mercado 2 .

Todos os isolados foram sorotipados compreendendo os sorotipos $1 / 2 \mathrm{c}(60,9 \%)$, 4b $(25,9 \%), 1 / 2 b(10,9 \%)$ e 1/2a (2,3\%). A ordem de prevalência de sorotipos obtidos nos quatro locais analisados separadamente não foi a mesma do cômputo geral, mas manteve-se a mesma no abatedouro 1 (1/2c $-94,37 \%, \mathbf{1 / 2 b}-4,23 \%, \mathbf{4 b}-0,70 \%$ e $\mathbf{1 / 2} \mathbf{a}-0,70 \%)$ e no abatedouro $2(\mathbf{1 / 2} \mathbf{c}-62,30 \%, \mathbf{1 / 2} \mathbf{b}-27,87 \%, \mathbf{4 b}-8,19 \%$ e $\mathbf{1 / 2} \mathbf{a}-$ 1,64\%), bem como no mercado 1 (4b - 60,27\%, $\mathbf{1 / 2 c}-30,14 \%, \mathbf{1 / 2 b}-9,59 \%$ e $\mathbf{1} / \mathbf{2} \mathbf{a}-$ $0 \%$ ) e mercado 2 (4b - 55,56\%, 1/2c - 25\%, $\mathbf{1 / 2} \mathbf{b}-11,11 \%$ e $\mathbf{1 / 2} \mathbf{a}-8,33 \%)$. Para o melhor entendimento, os sorotipos encontrados são apresentados na tabela 4, de acordo com sua distribuição nos locais de isolamento. 
Tabela 4 - Distribuição de sorotipos de Listeria monocytogenes de acordo com sua freqüência nas linhas de produção

\begin{tabular}{|c|c|c|c|c|}
\hline \multicolumn{5}{|c|}{ LINHA 1} \\
\hline \multicolumn{5}{|c|}{ Abatedouro 1} \\
\hline \multicolumn{5}{|c|}{ Língua e tonsilas } \\
\hline Sorotipo & $\begin{array}{c}\mathrm{n}^{\circ} \mathrm{de} \\
\text { amostras } \\
\text { positivas }\end{array}$ & $\begin{array}{c}\% \\
\text { amostras } \\
\text { positivas }\end{array}$ & $\begin{array}{c}\mathrm{n}^{\circ} \mathrm{de} \\
\text { colônias }\end{array}$ & $\%$ \\
\hline $1 / 2 b$ & 1 & 0,41 & 5 & 17,86 \\
\hline $1 / 2 c$ & 4 & 1,66 & 23 & 82,14 \\
\hline Total & 5 & 2,07 & 28 & 100 \\
\hline \multicolumn{5}{|c|}{ Ambientes } \\
\hline Sorotipo & $\begin{array}{c}\mathrm{n}^{\circ} \mathrm{de} \\
\text { amostras } \\
\text { positivas }\end{array}$ & $\begin{array}{c}\% \\
\text { amostras } \\
\text { positivas }\end{array}$ & $\begin{array}{c}\mathrm{n}^{\circ} \mathrm{de} \\
\text { colônias }\end{array}$ & $\%$ \\
\hline $1 / 2 a$ & 1 & 1,66 & 1 & 0,88 \\
\hline $1 / 2 b$ & 1 & 1,66 & 1 & 0,88 \\
\hline $1 / 2 c$ & 16 & 26,66 & 111 & 97,36 \\
\hline $4 b$ & 1 & 1,66 & 1 & 0,88 \\
\hline Total & 19 & 31,64 & 114 & 100 \\
\hline
\end{tabular}

\begin{tabular}{|c|c|c|c|c|}
\hline \multicolumn{5}{|c|}{$\begin{array}{c}\text { LINHA } 1 \\
\text { Mercado } 1\end{array}$} \\
\hline \multicolumn{5}{|c|}{ Carnes } \\
\hline Sorotipo & $\begin{array}{c}\mathrm{n}^{\circ} \mathrm{de} \\
\text { amostras } \\
\text { positivas }\end{array}$ & $\begin{array}{c}\% \\
\text { amostras } \\
\text { positivas }\end{array}$ & $\begin{array}{c}\mathrm{n}^{\circ} \mathrm{de} \\
\text { colônias }\end{array}$ & $\%$ \\
\hline $1 / 2 c$ & 1 & 1,66 & 18 & 72,00 \\
\hline $4 b$ & 1 & 1,66 & 7 & 28,00 \\
\hline Total & 2 & 3,32 & 25 & 100 \\
\hline \multicolumn{5}{|c|}{ Ambientes } \\
\hline Sorotipo & $\begin{array}{c}\mathrm{n}^{\circ} \mathrm{de} \\
\text { amostras } \\
\text { positivas }\end{array}$ & $\begin{array}{c}\% \\
\text { amostras } \\
\text { positivas }\end{array}$ & $\begin{array}{c}\mathrm{n}^{\circ} \mathrm{de} \\
\text { colônias }\end{array}$ & $\%$ \\
\hline $1 / 2 a$ & - & - & 0 & 0 \\
\hline $1 / 2 b$ & 2 & 5,55 & 7 & 14,60 \\
\hline $1 / 2 c$ & 1 & 2,77 & 4 & 8,30 \\
\hline $4 b$ & 6 & 16,66 & 37 & 70,10 \\
\hline Total & 9 & 24,98 & 48 & 100 \\
\hline
\end{tabular}

\begin{tabular}{|c|c|c|c|c|}
\hline \multicolumn{5}{|c|}{ LINHA 2} \\
\hline \multicolumn{5}{|c|}{ Abatedouro 2} \\
\hline \multicolumn{5}{|c|}{ Língua e tonsilas } \\
\hline Sorotipo & $\begin{array}{c}\mathrm{n}^{\circ} \mathrm{de} \\
\text { amostras } \\
\text { positivas }\end{array}$ & $\begin{array}{c}\% \\
\text { amostras } \\
\text { positivas }\end{array}$ & $\begin{array}{c}\mathrm{n}^{\circ} \mathrm{de} \\
\text { colônias }\end{array}$ & $\%$ \\
\hline- & - & - & - & - \\
\hline \multicolumn{5}{|l|}{ Total } \\
\hline \multicolumn{5}{|c|}{ Ambientes } \\
\hline Sorotipo & $\begin{array}{c}\mathrm{n}^{\circ} \mathrm{de} \\
\text { amostras } \\
\text { positivas }\end{array}$ & $\begin{array}{c}\% \\
\text { amostras } \\
\text { positivas }\end{array}$ & $\begin{array}{c}\mathrm{n}^{\circ} \mathrm{de} \\
\text { colônias }\end{array}$ & $\%$ \\
\hline $1 / 2 a$ & 1 & 1,66 & 1 & 1,63 \\
\hline $1 / 2 b$ & 3 & 5,00 & 17 & 27,87 \\
\hline $1 / 2 c$ & 5 & 8,33 & 38 & 62,30 \\
\hline $4 b$ & 2 & 3,33 & 5 & 8,20 \\
\hline Total & 11 & 18,32 & 61 & 100 \\
\hline
\end{tabular}

\begin{tabular}{|c|c|c|c|c|}
\hline \multicolumn{5}{|c|}{ LINHA 2} \\
\hline \multicolumn{5}{|c|}{ Mercado 2} \\
\hline \multicolumn{5}{|c|}{ Carnes } \\
\hline Sorotipo & $\begin{array}{c}\mathrm{n}^{\circ} \mathrm{de} \\
\text { amostras } \\
\text { positivas }\end{array}$ & $\begin{array}{c}\% \\
\text { amostras } \\
\text { positivas }\end{array}$ & $\begin{array}{c}\mathrm{n}^{\circ} \mathrm{de} \\
\text { colônias }\end{array}$ & $\%$ \\
\hline $1 / 2 b$ & 1 & 1,66 & 1 & 5,55 \\
\hline $4 b$ & 2 & 3,33 & 17 & 94,45 \\
\hline Total & 3 & 4,99 & 18 & 100 \\
\hline \multicolumn{5}{|c|}{ Ambientes } \\
\hline Sorotipo & $\begin{array}{c}\mathrm{n}^{\circ} \mathrm{de} \\
\text { amostras } \\
\text { positivas }\end{array}$ & $\begin{array}{c}\% \\
\text { amostras } \\
\text { positivas }\end{array}$ & $\begin{array}{c}\mathrm{n}^{\circ} \mathrm{de} \\
\text { colônias }\end{array}$ & $\%$ \\
\hline $1 / 2 a$ & 2 & 5,55 & 6 & 11,11 \\
\hline $1 / 2 b$ & 2 & 5,55 & 7 & 12,96 \\
\hline $1 / 2 c$ & 3 & 8,36 & 18 & 33,33 \\
\hline $4 b$ & 3 & 8,36 & 23 & 42,60 \\
\hline Total & 10 & 27,82 & 54 & 100 \\
\hline
\end{tabular}

Uma amostragem de 64 dos 348 isolados do presente estudo e dez isolados de casos clínicos de humanos de L. monocytogenes foram submetidos à realização da técnica de PFGE, utilizando-se a enzima de restrição Apal. A análise dos géis de PFGE revelou a presença de 23 pulsotipos, denominados PLA a PLZ, segundo o dendrograma (figura 3) que demonstra sua relação genética. A Tabela 5 especifica os isolados pertencentes a cada um dos pulsotipos. 


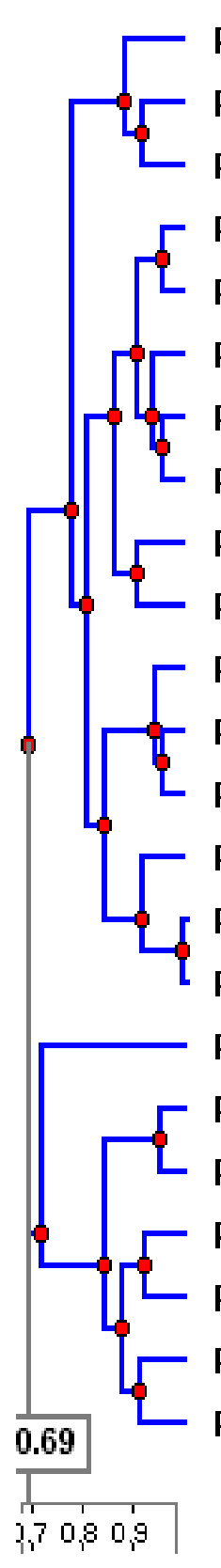

\section{PLG I I I I IIII III IIT}

PLM 1 I I IIII

PLP 1 I 11 II IIIIII

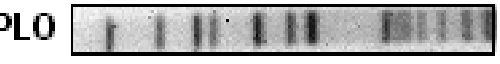

PLR I I II III IIITI

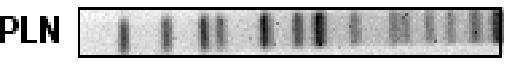

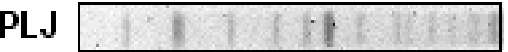

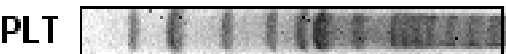

PLE AT/1/ II ala

PLL T.1.1. I HE I T.

PLA I I I I II III III IN

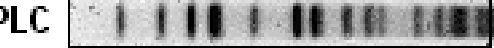

PLI | 1 II | IIIII IIIt)

PLD TII ITIt / I T T

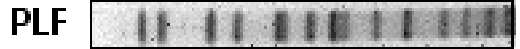

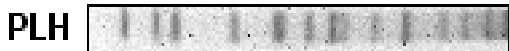

PLZ III III II 1

PLS AI A C E Ean

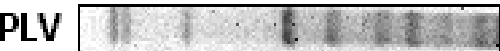

PLU 1 I

PLX

PLB 1 + I IfT I

PLQ $\|$ I I IInAIn

\begin{tabular}{cccccc}
\hline $\begin{array}{c}\text { Locais de } \\
\text { origem }\end{array}$ & Coleta & $\begin{array}{c}\mathbf{N}^{\circ} \text { de } \\
\text { isolados }\end{array}$ & Tipos de amostra & Sorotipos & Clusters \\
\hline Mercado 2 & 6 & 2 & chão & $4 \mathrm{~b}$ & \\
\hline Mercado 2 & 1 & 3 & mesa & $1 / 2 \mathrm{a}$ e 1/2b & $\mathrm{A}$ \\
\hline Mercado 2 & 2 & 4 & mesa & 1/2a e 1/2b &
\end{tabular}

\begin{tabular}{lcccc} 
Mercado 2 & 2 & 4 & mesa & $1 / 2 \mathrm{a}$ e $1 / 2 \mathrm{~b}$ \\
\hline Abatedouro 2 & 2 & 1 & mesa $\mathrm{AB}^{\mathrm{a}}$ & $1 / 2 \mathrm{~b}$ \\
\hline Mercado 2 & 9 & 2 & carne & $1 / 2 \mathrm{~b}$ \\
\hline Abatedouro 2 & 2 e 8 & 3 & mesa $\mathrm{AB}$ e chão $\mathrm{AB}$ & $1 / 2 \mathrm{~b}$
\end{tabular}

$\begin{array}{llllll}\text { Mercado } 1 & 2 & 1 & \text { chão } & 1 / 2 \mathrm{~b} & \mathrm{~B}\end{array}$

FIOCRUZ $\quad-\quad 1 \quad$ humano $\left(\mathrm{LCR}^{\mathrm{b}}-1983\right) \quad 1 / 2$

Mercado 1, $\quad 5,10 \mathrm{e} \quad$ chão, mesa e humano

$\begin{array}{lcclc}\begin{array}{l}\text { Mercado 2 } \\ \text { FIOCRUZ }\end{array} & \begin{array}{l}5,10 \mathrm{e} \\ 11\end{array} & 9 & \begin{array}{l}\text { chão, mesa e humano } \\ \left(\mathrm{sg}^{\mathrm{c}}-2004 \mathrm{e} \text { LCR }-1997\right)\end{array} & 4 \mathrm{~b}\end{array}$

$\begin{array}{lllll}\text { Mercado } 1 & 11 & 2 & \text { mesa }\end{array}$

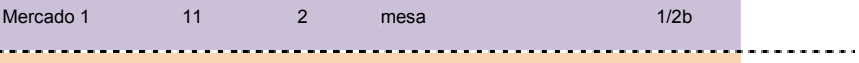

$\begin{array}{llll}\text { Mercado } 1 \text { e } & 2 & 3 & \text { chão e humano (sg - } \\ \text { FIOCRUZ } & & \text { 1977) }\end{array}$

Mercado $1-3,6$ e $8 \quad 6 \quad$ chão

\begin{tabular}{|c|c|c|c|c|}
\hline Mercado 2 & 11 & 2 & carne \\
\hline
\end{tabular}

\begin{tabular}{l|l|l|l|l|l|} 
Mercado 2 & 11 & 2 & carne & $4 \mathrm{~b}$ & \\
\hline Mercado 1 & 5 e 8 & 4 & chão e carne & & C
\end{tabular}

\begin{tabular}{l|l|l|l|l} 
Mercado 1 & 5 e 8 & 4 & chão e carne
\end{tabular}

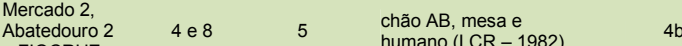

e FIOCRUZ $\quad 4$ e $8 \quad 5 \quad$ humano (LCR - 1982)

$\begin{array}{lllll}\text { Mercado } 2 & 7 & 2 & \text { carne }\end{array}$

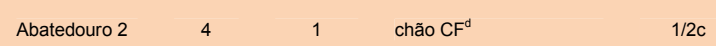

\begin{tabular}{|c|c|c|c|c|c|}
\hline FIOCRUZ & - & 1 & humano (sg - 1989) & $1 / 2 a$ & \multirow{6}{*}{$\mathrm{D}$} \\
\hline FIOCRUZ & - & 1 & humano (sg - 1985) & $1 / 2 a$ & \\
\hline FIOCRUZ & - & 1 & $\begin{array}{l}\text { humano (placenta - } \\
\text { 1978) }\end{array}$ & $1 / 2 a$ & \\
\hline $\begin{array}{l}\text { Abatedouro } 2 \\
\text { e Mercado } 2\end{array}$ & 7 e 11 & 2 & chão $A B$ e mesa & $1 / 2 \mathrm{c}$ & \\
\hline $\begin{array}{l}\text { Abatedouro 1, } \\
\text { Abatedouro } 2 \\
\text { e FIOCRUZ }\end{array}$ & $\begin{array}{c}3,4,7 \\
8,9 \\
10,11 \\
\text { e } 12\end{array}$ & 15 & $\begin{array}{l}\text { chão } C F \text {, mesa } A B \text {, } \\
\text { lingua/tonsila, parede } C F \\
\text { humano (LCR - 1983), } \\
\text { chão } A B \text { e mesa } A B\end{array}$ & $\begin{array}{c}4 b, 1 / 2 a \\
1 / 2 b \text { e } 1 / 2 c\end{array}$ & \\
\hline $\begin{array}{l}\text { Mercado } 1 \mathrm{e} \\
\text { Abatedouro } 2\end{array}$ & 2,5 e 8 & 3 & $\begin{array}{l}\text { chão, chão } A B \text { e mesa } \\
A B\end{array}$ & $1 / 2 \mathrm{c}$ & \\
\hline
\end{tabular}

${ }^{a} \mathrm{AB}$ : sala de abate

LCR: líquido cefalorraquidiano

'sg: sangue

Figura 3 - Dendrograma obtido pela análise dos géis de PFGE de Listeria monocytogenes utilizando a enzima de restrição Apal, baseado no coeficiente de similaridade de Dice, demonstrando a relação genética dos 23 pulsotipos gerados a partir de 64 isolados do presente estudo e de 10 isolados de casos clínicos de humanos 
Tabela 5 - Características dos isolados de Listeria monocytogenes e seus respectivos sorotipos

\begin{tabular}{|c|c|c|c|c|}
\hline \multicolumn{2}{|c|}{ sorotipos } & & & (contınua) \\
\hline Local de origem & Coleta & Tipo de amostra & Sorotipo & Pulsotipo \\
\hline Mercado 2 & 6 & chão & $4 b$ & PLG \\
\hline Mercado 2 & 6 & chão & $4 b$ & PLG \\
\hline Mercado 2 & 1 & mesa & $1 / 2 b$ & PLM \\
\hline Mercado 2 & 1 & mesa & $1 / 2 b$ & PLM \\
\hline Mercado 2 & 1 & mesa & $1 / 2 a$ & PLM \\
\hline Mercado 2 & 2 & mesa & $1 / 2 b$ & PLP \\
\hline Mercado 2 & 2 & mesa & $1 / 2 b$ & PLP \\
\hline Mercado 2 & 2 & mesa & $1 / 2 a$ & PLP \\
\hline Mercado 2 & 2 & mesa & $1 / 2 a$ & PLP \\
\hline Abatedouro 2 & 2 & mesa $A B^{a}$ & $1 / 2 b$ & PLO \\
\hline Mercado 2 & 9 & carne & $1 / 2 b$ & PLR \\
\hline Mercado 2 & 9 & carne & $1 / 2 b$ & PLR \\
\hline Abatedouro 2 & 2 & mesa $A B$ & $1 / 2 b$ & PLN \\
\hline Abatedouro 2 & 8 & chão AB & $1 / 2 b$ & PLN \\
\hline Abatedouro 2 & 8 & chão $A B$ & $1 / 2 b$ & PLN \\
\hline Mercado 1 & 2 & chão & $1 / 2 b$ & PLJ \\
\hline FIOCRUZ & - & HU61 - LCR ${ }^{6}$ (1983) & $1 / 2 b$ & PLT \\
\hline Mercado 1 & 11 & chão & $4 b$ & PLE \\
\hline Mercado 1 & 11 & chão & $4 b$ & PLE \\
\hline Mercado 2 & 5 & chão & $4 b$ & PLE \\
\hline Mercado 2 & 5 & chão & $4 b$ & PLE \\
\hline Mercado 2 & 10 & mesa & $4 b$ & PLE \\
\hline Mercado 2 & 10 & mesa & $4 b$ & PLE \\
\hline FIOCRUZ & - & HU10 - sg ${ }^{c}(2004)$ & $4 b$ & PLE \\
\hline FIOCRUZ & - & HU86 - LCR (1997) & $4 b$ & PLE \\
\hline FIOCRUZ & - & HU88 - LCR (1997) & $4 b$ & PLE \\
\hline Mercado 1 & 11 & mesa & $1 / 2 b$ & PLL \\
\hline Mercado 1 & 11 & mesa & $1 / 2 b$ & PLL \\
\hline Mercado 1 & 2 & chão & $4 b$ & PLA \\
\hline Mercado 1 & 2 & chão & $4 b$ & PLA \\
\hline FIOCRUZ & - & HU27 - sg (1977) & $4 b$ & PLA \\
\hline Mercado 1 & 3 & chão & $4 b$ & PLC \\
\hline Mercado 1 & 3 & chão & $4 b$ & PLC \\
\hline Mercado 1 & 6 & chão & $4 b$ & PLC \\
\hline Mercado 1 & 6 & chão & $4 b$ & PLC \\
\hline Mercado 1 & 8 & chão & $4 b$ & PLC \\
\hline Mercado 1 & 8 & chão & $4 b$ & PLC \\
\hline Mercado 2 & 11 & carne & $4 b$ & PLI \\
\hline Mercado 2 & 11 & carne & $4 b$ & PLI \\
\hline Mercado 1 & 5 & chão & $4 b$ & PLD \\
\hline Mercado 1 & 5 & chão & $4 b$ & PLD \\
\hline Mercado 1 & 8 & carne & $4 b$ & PLD \\
\hline Mercado 1 & 8 & carne & $4 b$ & PLD \\
\hline Abatedouro 2 & 4 & chão $A B$ & $4 b$ & PLF \\
\hline Abatedouro 2 & 4 & chão AB & $4 b$ & PLF \\
\hline Mercado 2 & 8 & mesa & $4 b$ & PLF \\
\hline Mercado 2 & 8 & mesa & $4 b$ & PLF \\
\hline FIOCRUZ & - & HU28 - LCR (1982) & $4 b$ & PLF \\
\hline Mercado 2 & 7 & carne & $4 b$ & PLH \\
\hline
\end{tabular}


(conclusão)

\begin{tabular}{|c|c|c|c|c|}
\hline Local de origem & Coleta & Tipo de amostra & Sorotipo & Pulsotipo \\
\hline Mercado 2 & 7 & carne & $4 \mathrm{~b}$ & PLH \\
\hline Abatedouro 2 & 4 & chão $\mathrm{CF}^{\mathrm{d}}$ & $1 / 2 \mathrm{c}$ & PLZ \\
\hline FIOCRUZ & - & HU06 - sg (1989) & $1 / 2 a$ & PLS \\
\hline FIOCRUZ & - & HU85 - sg (1985) & $1 / 2 a$ & PLV \\
\hline FIOCRUZ & - & HU63 - placenta (1978) & $1 / 2 a$ & PLU \\
\hline Abatedouro 2 & 11 & chão AB & $1 / 2 c$ & PLX \\
\hline Mercado 2 & 7 & mesa & $1 / 2 c$ & PLX \\
\hline Abatedouro 1 & 3 & chão CF & $4 b$ & PLB \\
\hline Abatedouro 1 & 8 & mesa $A B$ & $1 / 2 b$ & PLB \\
\hline Abatedouro 1 & 9 & língua/tonsila & $1 / 2 b$ & PLB \\
\hline Abatedouro 1 & 9 & língua/tonsila & $1 / 2 b$ & PLB \\
\hline Abatedouro 1 & 4 & parede CF & $1 / 2 a$ & PLB \\
\hline Abatedouro 2 & 4 & chão CF & $1 / 2 a$ & PLB \\
\hline FIOCRUZ & - & HU08 - LCR (1983) & $1 / 2 a$ & PLB \\
\hline Abatedouro 1 & 7 & chão $A B$ & $1 / 2 c$ & PLB \\
\hline Abatedouro 1 & 11 & chão $A B$ & $1 / 2 c$ & PLB \\
\hline Abatedouro 1 & 4 & mesa $A B$ & $1 / 2 c$ & PLB \\
\hline Abatedouro 1 & 8 & mesa $A B$ & $1 / 2 c$ & PLB \\
\hline Abatedouro 1 & 7 & chão CF & $1 / 2 c$ & PLB \\
\hline Abatedouro 1 & 10 & chão CF & $1 / 2 c$ & PLB \\
\hline Abatedouro 1 & 4 & parede CF & $1 / 2 c$ & PLB \\
\hline Abatedouro 1 & 12 & parede CF & $1 / 2 c$ & PLB \\
\hline Mercado 1 & 2 & chão & $1 / 2 c$ & PLQ \\
\hline Abatedouro 2 & 5 & chão $A B$ & $1 / 2 c$ & PLQ \\
\hline Abatedouro 2 & 8 & mesa $A B$ & $1 / 2 b$ & PLQ \\
\hline
\end{tabular}

${ }^{\mathrm{a} A B}$ : sala de abate

bLCR: líquido cefalorraquidiano

'sg: sangue

${ }^{\mathrm{d}} \mathrm{CF}$ : câmara fria

-os isolados de carne e língua/tonsilas pertencentes a uma mesma coleta são referentes a uma mesma amostra

Nas linhas coloridas estão os isolados que diferem dos demais em seus grupos (pulsotipos, clusters ou linhagens)

O perfil predominante foi PLB, com 20,27\% dos isolados genotipados, contendo isolados dos sorotipos $1 / 2$ a e $1 / 2 \mathrm{c}$, em sua grande parte, mas também alguns $1 / 2 \mathrm{~b}$ e $4 \mathrm{~b}$. Os perfis PLE, PLC e PLF também concentram grande número dos isolados genotipados, sendo: $12,16 \%, 8,11 \%$ e $6,76 \%$, respectivamente, todos contendo apenas isolados do sorotipo $4 \mathrm{~b}$.

Apesar da grande diversidade de pulsotipos, a maior parte dos perfis mostra grande similaridade entre si (maior que $80 \%$ ), gerando quatro clusters A (PLG, PLM e PLP), B (PLO, PLR, PLN, PLJ, PLT, PLE e PLL), C (PLA, PLC, PLI, PLD, PLF e PLH) e D (PLS, PLV, PLU, PLB, PLX e PLQ). Basicamente, os clusters A, B e C abrigam isolados dos sorotipos $4 \mathrm{~b}$ e $1 / 2 \mathrm{~b}$, representando a linhagem I de L. monocytogenes, com exceção do três isolados 1/2a (PLP e PLM). Além disso, neles se encontram a 
maioria dos isolados dos mercados e de casos clínicos de humanos, excetuando cinco isolados de abatedouro (PLO, PLN e PLF). Já o cluster D abriga isolados dos sorotipos 1/2a e 1/2c, representando a linhagem II, com exceção de cinco isolados pertencentes ao sorotipos $1 / 2 b$ e $4 b$ (PLB e PLQ). Neste cluster também se situam basicamente os isolados de abatedouros, a não ser por dois isolados de mercado (PLX e PLQ) e três dos casos clínicos de humanos (PLS, PLV e PLU).

Em relação à origem dos isolados, os de ambientes foram amplamente distribuídos em 16 dos 23 pulsotipos. Quanto aos isolados provenientes dos animais, os dois isolados de língua e tonsilas pertencentes ao sorotipo 1/2b (PLB), agruparam-se com isolados da linhagem II, entretanto os oito isolados de carne, pertencentes aos sorotipos 1/2b (PLR) e 4b (PLI, PLD e PLH) agruparam-se à linhagem I. 


\subsection{YERSINIA ENTEROCOLITICA}

Um total de 569 colônias foram caracterizadas como $Y$. enterocolitica através do exame bacteriológico e dos métodos bioquímicos; entretanto, por se tratar de um número grande de amostras e levando-se em consideração o intenso trabalho realizado para a bio-sorotipagem desta espécie, a partir da sétima coleta, apenas parte dos isolados suspeitos foi enviada para a caracterização fenotípica.

Foram enviados para bio-sorotipagem 459 isolados. Destes, foram confirmados como Y. enterocolitica 444 isolados (Tabelas 6, 7 e 8), sendo: 320 Y. enterocolitica 4/ O:3 (72,08\%), 92 Y. enterocolitica 1A não tipável (20,72\%), $10 Y$. enterocolitica 1A/ O:5a (2,25\%), 18 Y. enterocolitica $1 \mathrm{~A} / \mathrm{O}: 5 \mathrm{~b}(4,06 \%), 1$ Y. enterocolitica $1 \mathrm{~A} / \mathrm{O}$ 0:7 $(0,22 \%), 1$ Y. enterocolitica $1 \mathrm{~A} / 0: 6(0,22 \%)$ e 2 Y. enterocolitica rugosa $(0,45 \%)$, sendo que a maior parte desses isolados apresentou os genes relacionados aos fatores de virulência de $Y$. enterocolitica e ao sorotipo capsular 0:3 (os padrões desses isolados obtidos através da PCR estão descritos na Tabela 9 e ilustrados na Figura 4). Os 15 demais isolados não foram bio-sorotipados como $Y$. enterocolitica sendo: oito bacilos gram-negativos, imóveis e oxidase negativos; dois Citrobacter freundii; e cinco isolados sem crescimento após repique a partir do ágar estoque enviado. 
Tabela 6 - Distribuição mensal de isolamento de Yersinia enterocolitica em línguas e tonsilas de carcaças suínas e em ambientes de dois abatedouros do Estado de São Paulo

\begin{tabular}{|c|c|c|c|c|c|c|c|c|c|c|c|c|c|}
\hline \multirow{2}{*}{\multicolumn{2}{|c|}{$\begin{array}{c}\text { Tipo de amostra } \\
\text { (número de amostras/coleta) }\end{array}$}} & \multicolumn{12}{|c|}{ Abatedouro 1} \\
\hline & & Maio & Junho & Julho & Agosto & Setembro & Outubro & Novembro & Dezembro & Janeiro & Fevereiro & Março & Abril \\
\hline Língua+ton & as (20) & 0 & 0 & 24(5) & $1(1)$ & $37(7)$ & $29(8)$ & $9(4)$ & $31(16)$ & 18(15) & $8(6)$ & 15(12) & $8(6)$ \\
\hline \multirow{5}{*}{ Ambientes } & Chão AB* (1) & 0 & 0 & 0 & 0 & 1 & 0 & 0 & 0 & 0 & 0 & 0 & 0 \\
\hline & Parede AB (1) & 0 & 0 & 0 & 0 & 0 & 0 & 0 & 0 & 0 & 0 & 1 & 0 \\
\hline & Mesa AB (1) & 0 & 0 & 0 & 0 & 0 & 0 & 0 & 0 & 0 & 0 & 1 & 0 \\
\hline & Chão CF** (1) & 0 & 0 & 0 & 4 & 1 & 0 & 0 & 0 & 0 & 0 & 1 & 0 \\
\hline & Parede CF (1) & 0 & 0 & 0 & 0 & 0 & 1 & 0 & 0 & 0 & 1 & 0 & 0 \\
\hline
\end{tabular}

\begin{tabular}{|c|c|c|c|c|c|c|c|c|c|c|c|c|c|}
\hline \multirow{2}{*}{\multicolumn{2}{|c|}{$\begin{array}{c}\text { Tipo de amostra } \\
\text { (número de amostras/coleta) }\end{array}$}} & \multicolumn{12}{|c|}{ Abatedouro 2} \\
\hline & & Maio & Junho & Julho & Agosto & Setembro & Outubro & Novembro & Dezembro & Janeiro & Fevereiro & Março & Abri \\
\hline \multicolumn{2}{|c|}{ Língua+tonsilas(20) } & 0 & 0 & 22(4) & 32(14) & $8(3)$ & $29(10)$ & $11(5)$ & $3(2)$ & 18(12) & $13(12)$ & $2(2)$ & 2(1) \\
\hline \multirow{4}{*}{ Ambientes } & Chão $A B^{*}(1)$ & 0 & 0 & 0 & 1 & 0 & 0 & 0 & 0 & 0 & 0 & 1 & 0 \\
\hline & Parede AB (1) & 0 & 0 & 0 & 0 & 0 & 0 & 0 & 0 & 0 & 0 & 1 & 0 \\
\hline & Chão $C F^{* *}(1)$ & 0 & 0 & 7 & 0 & 0 & 0 & 0 & 0 & 2 & 1 & 0 & 0 \\
\hline & Parede CF (1) & 0 & 0 & 2 & 0 & 5 & 0 & 0 & 0 & 0 & 0 & 0 & 0 \\
\hline
\end{tabular}

${ }^{*} \mathrm{AB}$ : sala de abate; ${ }^{* *} \mathrm{CF}$ : câmara fria. 
Tabela 7 - Distribuição mensal de isolamento de Yersinia enterocolitica em carne suína e ambientes de dois mercados do Estado de São Paulo

\begin{tabular}{|c|c|c|c|c|c|c|c|c|c|c|c|c|c|}
\hline \multirow{2}{*}{\multicolumn{2}{|c|}{$\begin{array}{c}\text { Tipo de amostra } \\
\text { (número de amostras/coleta) }\end{array}$}} & \multicolumn{12}{|c|}{ Mercado 1} \\
\hline & & Maio & Junho & Julho & Agosto & Setembro & Outubro & Novembro & Dezembro & Janeiro $^{a}$ & Fevereiro $^{b}$ & Março ${ }^{b}$ & Abril $^{b}$ \\
\hline \multicolumn{2}{|c|}{ Carnes (5) } & 0 & 0 & 0 & 0 & 0 & 0 & 0 & 0 & 0 & $4(4)$ & 0 & $1(1)$ \\
\hline \multirow{3}{*}{ Ambientes } & Chão (1) & 0 & 0 & 1 & 0 & 0 & 0 & 0 & 0 & 0 & 1 & 1 & 0 \\
\hline & Parede (1) & 0 & 0 & 0 & 0 & 0 & 0 & 0 & 0 & 0 & 0 & 0 & 0 \\
\hline & Mesa (1) & 0 & 0 & 0 & 0 & 0 & 0 & 0 & 0 & 0 & 1 & 1 & 0 \\
\hline
\end{tabular}

\begin{tabular}{|c|c|c|c|c|c|c|c|c|c|c|c|c|c|}
\hline \multirow{2}{*}{\multicolumn{2}{|c|}{$\begin{array}{c}\text { Tipo de amostra } \\
\text { (número de amostras/coleta) }\end{array}$}} & \multicolumn{12}{|c|}{ Mercado 2} \\
\hline & & Maio & Junho & Julho & Agosto & Setembro & Outubro & Novembro & Dezembro & Janeiro & Fevereiro & Março & Abril \\
\hline \multicolumn{2}{|c|}{ Carnes (5) } & 0 & 0 & $5(2)$ & $10(3)$ & 0 & $5(2)$ & 0 & 0 & 0 & $4(4)$ & $4(4)$ & 0 \\
\hline \multirow[b]{2}{*}{ Ambientes } & Chão (1) & 0 & 0 & 0 & 2 & 0 & 6 & 0 & 0 & 1 & 1 & 1 & 0 \\
\hline & Parede (1) & 0 & 0 & 0 & 3 & 5 & 6 & 3 & 0 & 0 & 1 & 0 & 0 \\
\hline
\end{tabular}

${ }^{a}$ mercado não recebeu carne do abatedouro $1 ;{ }^{b}$ outro mercado - carne recebida do abatedouro 1, mas de novos ambientes. 
Tabela 8 - Bio-sorotipos dos isolados de Yersinia enterocolitica (número de colônias)

\begin{tabular}{|c|c|c|c|c|c|c|c|c|}
\hline Local & $\begin{array}{c}Y e \\
4 / 0: 3 \\
\end{array}$ & $\begin{array}{c}Y e \\
1 \mathrm{~A} / \mathrm{NT}\end{array}$ & $\begin{array}{c}Y e \\
1 \mathrm{~A} / \mathrm{O}: 5 \mathrm{a}\end{array}$ & $\begin{array}{c}Y e \\
1 \mathrm{~A} / O: 5 \mathrm{~b}\end{array}$ & $\begin{array}{c}Y e \\
1 \mathrm{~A} / \mathrm{O}: 7\end{array}$ & $\begin{array}{c}Y e \\
1 \mathrm{~A} / \mathrm{O}: 6\end{array}$ & $\begin{array}{c}Y e \\
\text { rugosa }\end{array}$ & Total \\
\hline Abatedouro 1 & 182 & 1 & 1 & 6 & 0 & 1 & 0 & 191 \\
\hline Mercado 1 & 0 & 6 & 2 & 1 & 0 & 0 & 1 & 10 \\
\hline Abatedouro 2 & 138 & 20 & 2 & 2 & 0 & 0 & 1 & 163 \\
\hline Mercado 2 & 0 & 65 & 5 & 9 & 1 & 0 & 0 & 80 \\
\hline Total & 320 & 92 & 10 & 18 & 1 & 1 & 2 & 444 \\
\hline
\end{tabular}

Tabela 9 - Padrões dos genótipos obtidos através da PCR para caracterização dos isolados de Yersinia enterocolitica bio-sorotipados [presença (+)/ ausência (-)]

\begin{tabular}{|c|c|c|c|c|c|c|c|c|c|c|c|}
\hline \multicolumn{4}{|c|}{ Padrão na PCR } & \multirow{2}{*}{$\begin{array}{c}Y e \\
4 / 0: 3 \\
267 \\
\end{array}$} & \multirow{2}{*}{$\begin{array}{c}Y e \\
\text { 1A/NT }\end{array}$} & \multirow{2}{*}{$\begin{array}{c}\begin{array}{c}Y e \\
\text { 1A/O:5a }\end{array} \\
7\end{array}$} & \multirow{2}{*}{$\begin{array}{c}\begin{array}{c}Y e \\
\text { 1A/O:5b }\end{array} \\
16\end{array}$} & \multirow{2}{*}{$\begin{array}{c}e \\
\text { 1A/O:7 } \\
- \\
\end{array}$} & \multirow{2}{*}{$\begin{array}{c}\text { Ye } \\
\text { 1A/O:6 } \\
-\end{array}$} & \multirow{2}{*}{$\begin{array}{c}\begin{array}{c}Y e \\
\text { rugosa }\end{array} \\
2\end{array}$} & \multirow{2}{*}{$\begin{array}{c}\begin{array}{c}\text { Número de } \\
\text { colônias }\end{array} \\
336\end{array}$} \\
\hline $\begin{array}{c}\text { virF } \\
+\end{array}$ & $\begin{array}{c}\text { ail } \\
+\end{array}$ & $\begin{array}{c}r f b C \\
+\end{array}$ & $\begin{array}{c}\text { yst } \\
+\end{array}$ & & & & & & & & \\
\hline $\begin{array}{c}\text { virF } \\
-\end{array}$ & $\begin{array}{c}\text { ail } \\
+\end{array}$ & $\begin{array}{c}r f b C \\
+\end{array}$ & $\begin{array}{c}\text { yst } \\
+\end{array}$ & 40 & 3 & - & 1 & - & - & - & 44 \\
\hline $\begin{array}{c}\text { virF } \\
+\end{array}$ & $\begin{array}{l}\text { ail } \\
-\end{array}$ & $\begin{array}{c}r f b C \\
+\end{array}$ & $\begin{array}{c}y s t \\
+\end{array}$ & - & 1 & - & - & - & - & - & 1 \\
\hline $\begin{array}{c}\text { virF } \\
+\end{array}$ & $\begin{array}{c}\text { ail } \\
+\end{array}$ & $\begin{array}{c}r f b C \\
+\end{array}$ & $\begin{array}{c}y s t \\
-\end{array}$ & - & 1 & - & 1 & - & - & - & 2 \\
\hline $\begin{array}{c}\text { virF } \\
+\end{array}$ & ail & $\begin{array}{c}r f b C \\
+\end{array}$ & $\begin{array}{c}\text { yst } \\
-\end{array}$ & - & 17 & - & - & - & - & - & 17 \\
\hline $\begin{array}{c}\text { virF } \\
-\end{array}$ & ail & $\begin{array}{c}r f b C \\
+\end{array}$ & $\begin{array}{c}y s t \\
+\end{array}$ & 6 & 1 & - & - & - & - & - & 7 \\
\hline $\begin{array}{c}\text { virF } \\
-\end{array}$ & ail & $\begin{array}{c}r f b C \\
+\end{array}$ & $\begin{array}{c}y s t \\
-\end{array}$ & - & 6 & - & - & - & - & - & 6 \\
\hline $\begin{array}{c}\text { virF } \\
-\end{array}$ & $\begin{array}{c}\text { ail } \\
+\end{array}$ & $\begin{array}{c}r f b C \\
-\end{array}$ & $\begin{array}{c}y s t \\
-\end{array}$ & - & 2 & - & - & - & - & - & 2 \\
\hline $\begin{array}{c}\text { virF } \\
-\end{array}$ & $\begin{array}{l}\text { ail } \\
-\end{array}$ & $r f b C$ & $\begin{array}{c}y s t \\
+\end{array}$ & 7 & - & - & - & - & - & - & 7 \\
\hline $\begin{array}{c}\text { virF } \\
-\end{array}$ & ail & $\begin{array}{c}r f b C \\
-\end{array}$ & yst & - & 17 & 3 & - & 1 & 1 & - & 22 \\
\hline & & & & 320 & 92 & 10 & 18 & 1 & 1 & 2 & 444 \\
\hline
\end{tabular}

*ail - gene cromossomal de adesão e invasão, virF - plasmídeo de virulência, yst - enterotoxina termoestável, rfbC - região específica para o sorotipo 0:3. 


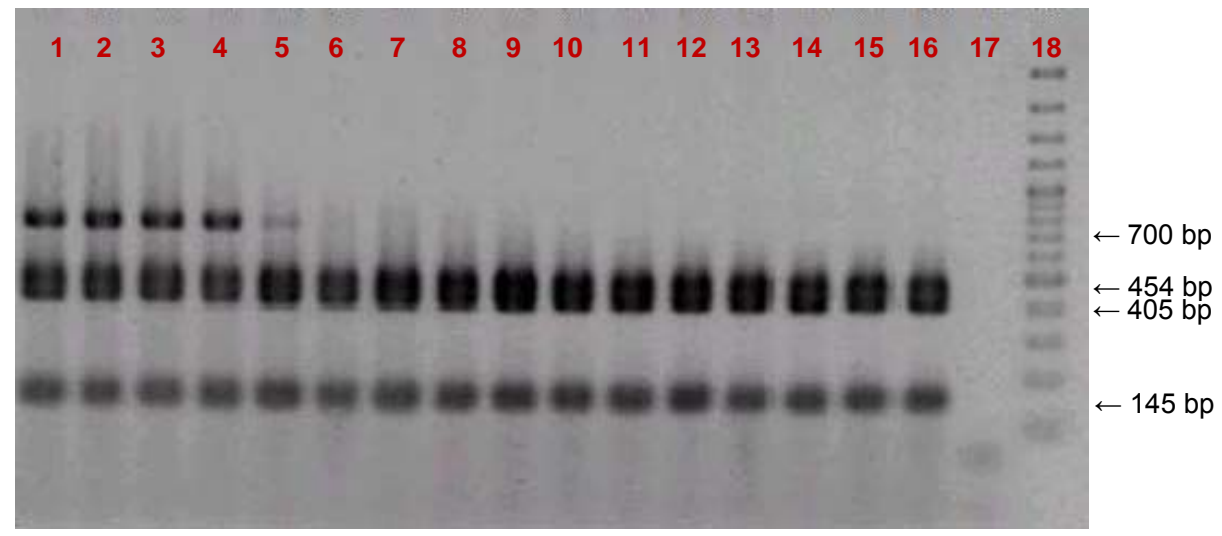

Figura 4 - Multiplex PCR de isolados de Yersinia enterocolitica. Colunas 1 a 15: isolados de amostras coletadas em abatedouros; coluna 16: amostra positiva - Yersinia enterocolitica O:3 MyO - SW/897/63 - biotipo 4;coluna 17: controle negativo; coluna 18: marcador $100 \mathrm{bp}$ Ladder (LGC Technologies).yst - 145 bp; rfbC - 405 bp; ail - 454 bp; virF - 700 bp.

Das 120 amostras de ambientes de abatedouros e 72 de ambientes de mercados coletadas, apenas $1,66 \%(2 / 120)$ das amostras de abatedouro foram positivas para $Y$. enterocolitica 4/ O:3. O abatedouro 1, de menor capacidade de abates diários, apresentou estes dois únicos ambientes positivos, totalizando $3,33 \%$ (2/60) de seus ambientes. Em relação ao abatedouro 2, de alta capacidade de abate, e aos mercados 1 e 2 , nenhum apresentou qualquer isolado positivo para $Y$. enterocolitica 4/ 0:3.

Das amostras representativas dos animais, 30\% (144/480) amostras de língua e tonsilas apresentaram isolamento positivo para $Y$. enterocolitica $4 / 0: 3$, sendo $33,33 \%$ (80/240) em relação às amostras do abatedouro 1 e $26,67 \%(64 / 240)$ do abatedouro 2. Quanto às amostras de carnes, de ambos os mercados, num total de 120, nenhuma foi positiva para presença do bio-sorotipo patogênico 4/O:3.

Todos os isolados de $Y$. enterocolitica bio-sorotipados como a patogênica 4/ 0:3 e outros não patogênicos, estão distribuídos na tabela 10 conforme sua freqüência de isolamento em cada local referido a fim de uma melhor visualização. 
Tabela 10 - Distribuição de bio-sorotipos de Yersinia enterocolitica de acordo com suas freqüências nas linhas de produção

\begin{tabular}{|c|c|c|c|c|}
\hline \multicolumn{5}{|c|}{ LINHA 1} \\
\hline \multicolumn{5}{|c|}{ Abatedouro 1} \\
\hline \multicolumn{5}{|c|}{ Língua e tonsilas } \\
\hline $\begin{array}{c}\text { Bio- } \\
\text { sorotipo }\end{array}$ & $\begin{array}{c}\mathrm{n}^{\circ} \mathrm{de} \\
\text { amostras } \\
\text { positivas }\end{array}$ & $\%$ & $\begin{array}{c}\mathrm{n}^{\circ} \mathrm{de} \\
\text { colônias }\end{array}$ & $\%$ \\
\hline 4/ O:3 & 80 & 33,33 & 180 & 100 \\
\hline 1A/NT & - & - & - & - \\
\hline $1 \mathrm{~A} / 0: 5 \mathrm{a}$ & - & - & - & - \\
\hline $1 \mathrm{~A} / 0: 5 \mathrm{~b}$ & - & - & - & - \\
\hline $1 \mathrm{~A} / \mathrm{O}: 7$ & - & - & - & - \\
\hline 1A/O:6 & - & - & - & - \\
\hline rugosa & - & - & - & - \\
\hline Total & 80 & 33,33 & 180 & 100 \\
\hline \multicolumn{5}{|c|}{ Ambientes } \\
\hline $\begin{array}{c}\text { Bio- } \\
\text { sorotipo }\end{array}$ & $\begin{array}{c}\mathrm{n}^{\circ} \text { de } \\
\text { amostras } \\
\text { positivas }\end{array}$ & $\%$ & $\begin{array}{c}\mathrm{n}^{\circ} \mathrm{de} \\
\text { colônias }\end{array}$ & $\%$ \\
\hline $4 / 0: 3$ & 1 & 1,66 & 2 & 18,18 \\
\hline 1A/NT & 1 & 1,66 & 1 & 9,09 \\
\hline $1 \mathrm{~A} / 0: 5 \mathrm{a}$ & 1 & 1,66 & 1 & 9,09 \\
\hline $1 \mathrm{~A} / 0: 5 \mathrm{~b}$ & 3 & 5,00 & 6 & 54,55 \\
\hline 1A/O:7 & - & - & - & - \\
\hline $1 \mathrm{~A} / 0: 6$ & 1 & 1,66 & 1 & 9,09 \\
\hline rugosa & - & - & - & - \\
\hline Total & 7 & 11,64 & 11 & 100 \\
\hline
\end{tabular}

\begin{tabular}{|c|c|c|c|c|}
\hline \multicolumn{5}{|c|}{ LINHA 1} \\
\hline \multicolumn{5}{|c|}{ Mercado 1} \\
\hline \multicolumn{5}{|c|}{ Carnes } \\
\hline $\begin{array}{l}\text { Bio- } \\
\text { sorotipo }\end{array}$ & $\begin{array}{c}\mathrm{n}^{\circ} \text { de } \\
\text { amostras } \\
\text { positivas }\end{array}$ & $\%$ & $\begin{array}{c}\mathrm{n}^{\circ} \mathrm{de} \\
\text { colônias }\end{array}$ & $\%$ \\
\hline 4/ O:3 & - & - & - & - \\
\hline 1A/NT & 4 & 6,66 & 4 & 80 \\
\hline $1 \mathrm{~A} / 0: 5 \mathrm{a}$ & 1 & 1,66 & 1 & 20 \\
\hline $1 \mathrm{~A} / 0: 5 \mathrm{~b}$ & - & - & - & - \\
\hline 1A/O:7 & - & - & - & - \\
\hline $1 \mathrm{~A} / 0: 6$ & - & - & - & - \\
\hline rugosa & - & - & - & - \\
\hline Total & 5 & 8,32 & 5 & 100 \\
\hline \multicolumn{5}{|c|}{ Ambientes } \\
\hline $\begin{array}{c}\text { Bio- } \\
\text { sorotipo }\end{array}$ & $\begin{array}{c}\mathrm{n}^{\circ} \mathrm{de} \\
\text { amostras } \\
\text { positivas }\end{array}$ & $\%$ & $\begin{array}{c}\mathrm{n}^{\circ} \mathrm{de} \\
\text { colônias }\end{array}$ & $\%$ \\
\hline 4/ O:3 & - & - & - & - \\
\hline 1A/NT & 2 & 5,55 & 2 & 40 \\
\hline $1 \mathrm{~A} / 0: 5 \mathrm{a}$ & 1 & 2,77 & 1 & 20 \\
\hline $1 \mathrm{~A} / 0: 5 \mathrm{~b}$ & 1 & 2,77 & 1 & 20 \\
\hline 1A/O:7 & - & - & - & - \\
\hline $1 \mathrm{~A} / \mathrm{O}: 6$ & - & - & - & - \\
\hline rugosa & 1 & 2,77 & 1 & 20 \\
\hline Total & 5 & 13,86 & 5 & 100 \\
\hline
\end{tabular}

\begin{tabular}{|c|c|c|c|c|}
\hline \multicolumn{5}{|c|}{ LINHA 2} \\
\hline \multicolumn{5}{|c|}{ Abatedouro 2} \\
\hline \multicolumn{5}{|c|}{ Língua e tonsilas } \\
\hline $\begin{array}{l}\text { Bio- } \\
\text { sorotipo }\end{array}$ & $\begin{array}{c}\mathrm{n}^{\circ} \text { de } \\
\text { amostras } \\
\text { positivas }\end{array}$ & $\%$ & $\begin{array}{c}\mathrm{n}^{\circ} \mathrm{de} \\
\text { colônias }\end{array}$ & $\%$ \\
\hline $4 / 0: 3$ & 52 & 21,66 & 138 & 98,57 \\
\hline $1 \mathrm{~A} / \mathrm{NT}$ & 2 & 0,83 & 2 & 1,43 \\
\hline $1 \mathrm{~A} / 0: 5 a$ & - & - & - & - \\
\hline $1 \mathrm{~A} / 0: 5 \mathrm{~b}$ & - & - & - & - \\
\hline $1 \mathrm{~A} / \mathrm{O}: 7$ & - & - & - & - \\
\hline 1A/O:6 & - & - & - & - \\
\hline rugosa & - & - & - & - \\
\hline Total & 54 & 22,49 & 140 & 100 \\
\hline \multicolumn{5}{|c|}{ Ambientes } \\
\hline $\begin{array}{l}\text { Bio- } \\
\text { sorotipo }\end{array}$ & $\begin{array}{c}\mathrm{n}^{\circ} \text { de } \\
\text { amostras } \\
\text { positivas }\end{array}$ & $\%$ & $\begin{array}{c}\mathrm{n}^{\circ} \mathrm{de} \\
\text { colônias }\end{array}$ & $\%$ \\
\hline $4 / 0: 3$ & - & - & - & - \\
\hline 1A/NT & 7 & 11,66 & 18 & 78,26 \\
\hline $1 \mathrm{~A} / 0: 5 \mathrm{a}$ & 1 & 1,66 & 2 & 8,70 \\
\hline $1 \mathrm{~A} / 0: 5 \mathrm{~b}$ & 1 & 1,66 & 2 & 8,70 \\
\hline 1A/O:7 & - & - & - & - \\
\hline 1A/O:6 & - & - & - & - \\
\hline rugosa & 1 & 1,66 & 1 & 4,34 \\
\hline Total & 10 & 16,64 & 23 & 100 \\
\hline
\end{tabular}

\begin{tabular}{|c|c|c|c|c|}
\hline \multicolumn{5}{|c|}{ LINHA 2} \\
\hline \multicolumn{5}{|c|}{ Mercado 2} \\
\hline \multicolumn{5}{|c|}{ Carnes } \\
\hline $\begin{array}{l}\text { Bio- } \\
\text { sorotipo }\end{array}$ & $\begin{array}{c}\mathrm{n}^{\circ} \text { de } \\
\text { amostras } \\
\text { positivas }\end{array}$ & $\%$ & $\begin{array}{c}\mathrm{n}^{\circ} \mathrm{de} \\
\text { colônias }\end{array}$ & $\%$ \\
\hline $4 / 0: 3$ & - & - & - & - \\
\hline $1 \mathrm{~A} / \mathrm{NT}$ & 13 & 21,66 & 22 & 78,57 \\
\hline $1 \mathrm{~A} / 0: 5 a$ & 2 & 3,33 & 2 & 7,14 \\
\hline $1 \mathrm{~A} / \mathrm{O}: 5 \mathrm{~b}$ & 2 & 3,33 & 4 & 14,29 \\
\hline 1A/O:7 & - & - & - & - \\
\hline 1A/O:6 & - & - & - & - \\
\hline rugosa & - & - & - & - \\
\hline Total & 17 & 28,32 & 28 & 100 \\
\hline \multicolumn{5}{|c|}{ Ambientes } \\
\hline $\begin{array}{c}\text { Bio- } \\
\text { sorotipo }\end{array}$ & $\begin{array}{c}\mathrm{n}^{\circ} \text { de } \\
\text { amostras } \\
\text { positivas }\end{array}$ & $\%$ & $\begin{array}{c}\mathrm{n}^{\circ} \mathrm{de} \\
\text { colônias }\end{array}$ & $\%$ \\
\hline $4 / 0: 3$ & - & - & - & - \\
\hline $1 \mathrm{~A} / \mathrm{NT}$ & 16 & 44,44 & 43 & 82,70 \\
\hline $1 \mathrm{~A} / 0: 5 \mathrm{a}$ & 3 & 8,33 & 3 & 5,77 \\
\hline $1 \mathrm{~A} / \mathrm{O}: 5 \mathrm{~b}$ & 4 & 11,11 & 5 & 9,61 \\
\hline 1A/O:7 & 1 & 2,77 & 1 & 1,92 \\
\hline 1A/O:6 & - & - & - & - \\
\hline rugosa & - & - & - & - \\
\hline Total & 24 & 66,65 & 52 & 100 \\
\hline
\end{tabular}


Uma amostragem de 84 dos 320 isolados de $Y$. enterocolitica 4/ 0:3 foi selecionada para realização da técnica de PFGE, juntamente com doze isolados de casos clínicos em humanos, para comparação utilizando-se a enzima de restrição Notl.

Além desses, mais 24 isolados de $Y$. enterocolitica 1A (do total de 122 deste estudo) também foram submetidos à PFGE para se avaliar a possibilidade de relação com os isolados de $Y$. enterocolitica 4/ 0:3. Entretanto, houve grande diferença de padrão de seus perfis quando comparados aos padrões dos perfis de isolados de $Y$. enterocolitica 4/ $0: 3$, demonstrando que não há correlação epidemiológica entre esses bio-sorotipos (Figura 5) e, por isso, os isolados de $Y$. enterocolitica $1 \mathrm{~A}$ não tiveram seus géis analisados para formação do dendrograma.

A análise dos géis de PFGE foi realizada apenas com fragmentos gerados acima de $70 \mathrm{~kb}$, o que impede a interferência do plasmídeo nos padrões produzidos por qualquer enzima de restrição, já que este se situa num fragmento de aproximadamente 40kb (FREDRIKSSON-AHOMAA et al., 2001a). Ela revelou a presença de 15 pulsotipos diferentes para as de $Y$. enterocolitica 4/ O:3, denominados PYA a PYP, segundo o dendrograma (Figura 6) que demonstra sua relação genética. A tabela 11 especifica os isolados pertencentes a cada um dos pulsotipos. 


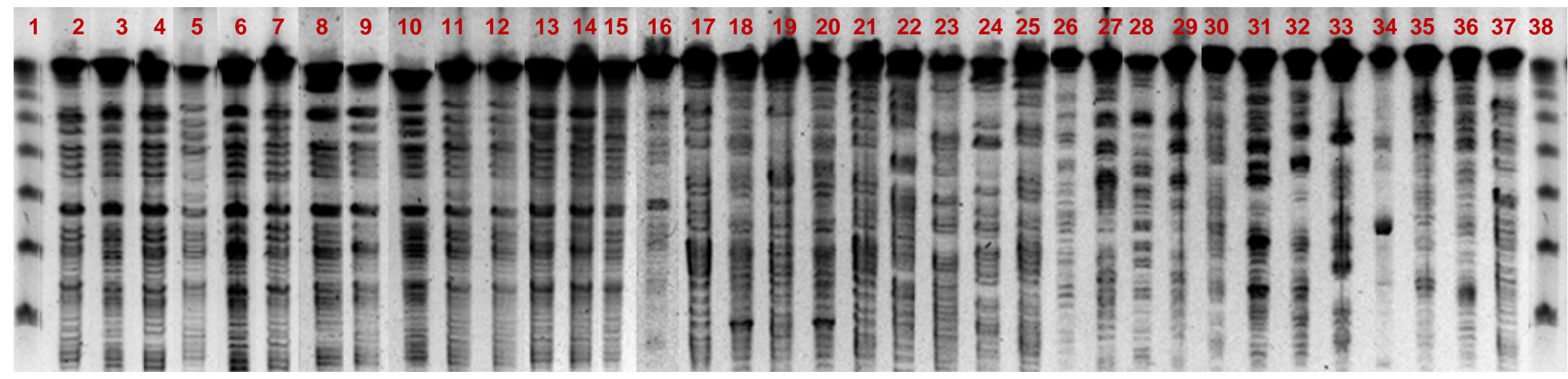

Figura 5 - Eletroforese em campo pulsado - Yersinia enterocolitica. Colunas 1 e 38: marcador Lambda (New England BioLabs, New England); colunas 2 a 16: pulsotipos gerados dos isolados de Yersinia enterocolitica 4, O:3 (PYA a PYP); colunas 17 a 37 : isolados de Yersinia enterocolitica $1 \mathrm{~A}$ 


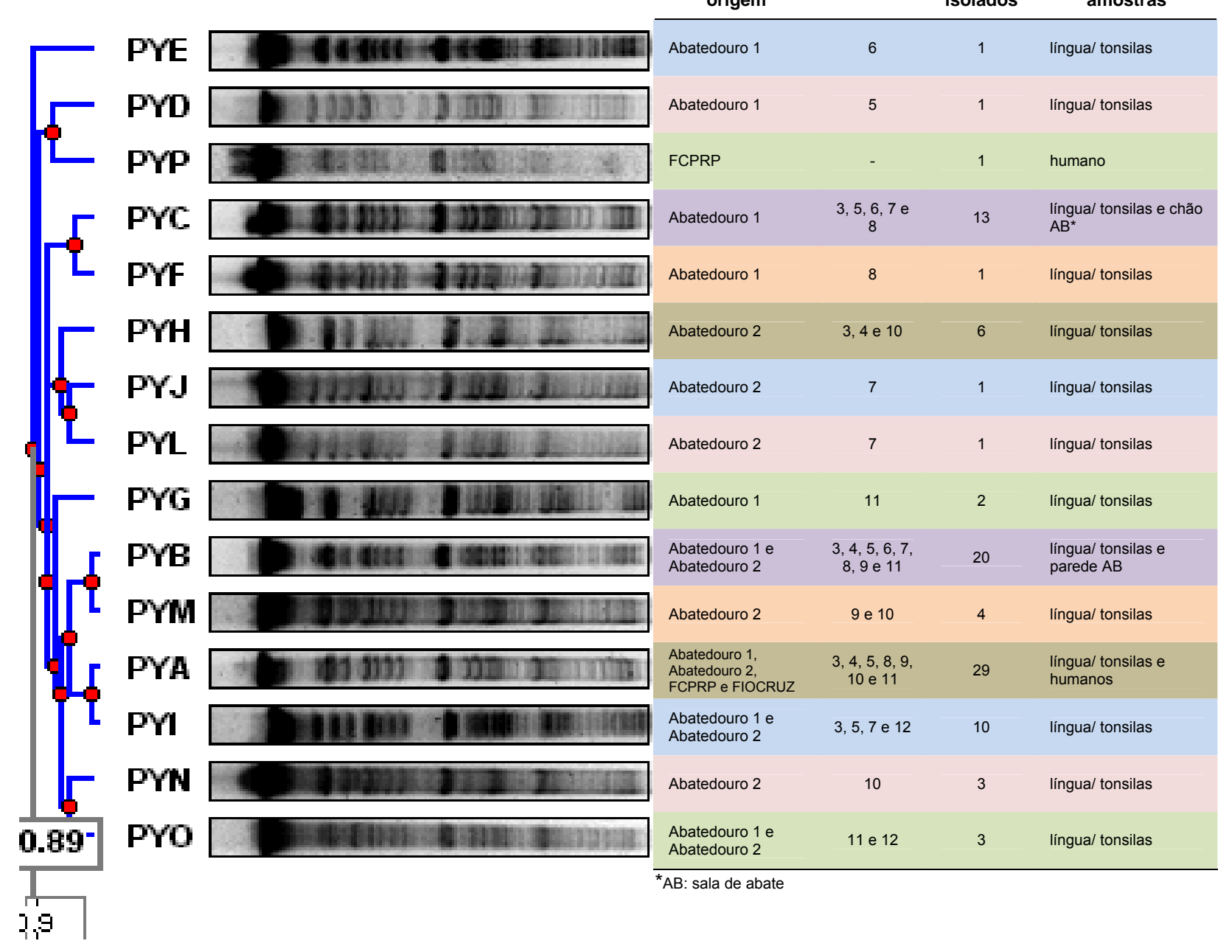

Figura 6 - Dendrograma obtido pela análise dos géis de PFGE de Yersinia enterocolitica 4/ O:3, utilizando a enzima de restrição Notl, baseado no coeficiente de similaridade de Dice, demonstrando a relação genética dos 15 pulsotipos gerados a partir de 84 isolados obtidos neste estudo e de 12 isolados de casos clínicos de humanos 
Tabela 11 - Características de Yersinia enterocolitica 4/ 0:3 isoladas de línguas e tonsilas de carcaças de suínos e ambientes de dois abatedouros do Estado de São Paulo, bem como de isolados de casos clínicos em humanos de diferentes origens

\begin{tabular}{|c|c|c|c|c|}
\hline & \multirow{2}{*}{$\mathrm{N}^{\circ}$ da amostra* } & \multirow{2}{*}{ Tipo de amostra } & \multirow{2}{*}{ Pulsotipo } \\
\hline Local de origem & Coleta & & & \\
\hline Abatedouro 1 & 6 & 12 & língua/ tonsilas & PYE \\
\hline Abatedouro 1 & 5 & 1 & língua/ tonsilas & PYD \\
\hline FCPRP & - & - & FCF 414 & PYP \\
\hline Abatedouro 1 & 3 & 14 & língua/tonsilas & PYC \\
\hline Abatedouro 1 & 3 & 19 & língua/ tonsilas & PYC \\
\hline Abatedouro 1 & 5 & 1 & chão AB & PYC \\
\hline Abatedouro 1 & 6 & 7 & língua/ tonsilas & PYC \\
\hline Abatedouro 1 & 6 & 10 & língua/ tonsilas & PYC \\
\hline Abatedouro 1 & 6 & 15 & língua/ tonsilas & PYC \\
\hline Abatedouro 1 & 6 & 20 & língua/ tonsilas & PYC \\
\hline Abatedouro 1 & 7 & 13 & língua/ tonsilas & PYC \\
\hline Abatedouro 1 & 7 & 13 & língua/ tonsilas & PYC \\
\hline Abatedouro 1 & 7 & 20 & língua/ tonsilas & PYC \\
\hline Abatedouro 1 & 7 & 20 & língua/ tonsilas & PYC \\
\hline Abatedouro 1 & 8 & 2 & língua/ tonsilas & PYC \\
\hline Abatedouro 1 & 8 & 8 & língua/ tonsilas & PYC \\
\hline Abatedouro 1 & 8 & 1 & língua/ tonsilas & PYF \\
\hline Abatedouro 2 & 3 & 15 & língua/ tonsilas & PYH \\
\hline Abatedouro 2 & 3 & 15 & língua/ tonsilas & PYH \\
\hline Abatedouro 2 & 3 & 19 & língua/ tonsilas & PYH \\
\hline Abatedouro 2 & 4 & 1 & língua/ tonsilas & $\mathrm{PYH}$ \\
\hline Abatedouro 2 & 4 & 18 & língua/ tonsilas & $\mathrm{PYH}$ \\
\hline Abatedouro 2 & 10 & 6 & língua/ tonsilas & PYH \\
\hline Abatedouro 2 & 7 & 1 & língua/ tonsilas & PYJ \\
\hline Abatedouro 2 & 7 & 3 & língua/ tonsilas & PYL \\
\hline Abatedouro 1 & 11 & 6 & língua/ tonsilas & PYG \\
\hline Abatedouro 1 & 11 & 18 & língua/ tonsilas & PYG \\
\hline Abatedouro 1 & 3 & 8 & língua/ tonsilas & PYB \\
\hline Abatedouro 1 & 3 & 13 & língua/ tonsilas & PYB \\
\hline Abatedouro 1 & 5 & 10 & língua/ tonsilas & PYB \\
\hline Abatedouro 1 & 7 & 14 & língua/ tonsilas & PYB \\
\hline Abatedouro 1 & 11 & 11 & língua/ tonsilas & PYB \\
\hline Abatedouro 1 & 11 & 1 & parede $A B$ & PYB \\
\hline Abatedouro 2 & 3 & 2 & língua/ tonsilas & PYB \\
\hline Abatedouro 2 & 3 & 5 & língua/ tonsilas & PYB \\
\hline Abatedouro 2 & 4 & 5 & língua/ tonsilas & PYB \\
\hline Abatedouro 2 & 4 & 10 & língua/ tonsilas & PYB \\
\hline Abatedouro 2 & 4 & 14 & língua/ tonsilas & PYB \\
\hline Abatedouro 2 & 5 & 18 & língua/ tonsilas & PYB \\
\hline Abatedouro 2 & 6 & 2 & língua/ tonsilas & PYB \\
\hline Abatedouro 2 & 6 & 8 & língua/ tonsilas & PYB \\
\hline Abatedouro 2 & 6 & 13 & língua/ tonsilas & PYB \\
\hline Abatedouro 2 & 6 & 15 & língua/ tonsilas & PYB \\
\hline Abatedouro 2 & 6 & 18 & língua/ tonsilas & PYB \\
\hline Abatedouro 2 & 8 & 1 & língua/ tonsilas & PYB \\
\hline Abatedouro 2 & 8 & 9 & língua/ tonsilas & PYB \\
\hline Abatedouro 2 & 9 & 1 & língua/ tonsilas & PYB \\
\hline Abatedouro 2 & 9 & 10 & língua/ tonsilas & PYM \\
\hline Abatedouro 2 & 9 & 16 & língua/ tonsilas & PYM \\
\hline Abatedouro 2 & 9 & 18 & língua/ tonsilas & PYM \\
\hline Abatedouro 2 & 10 & 3 & língua/ tonsilas & PYM \\
\hline Abatedouro 1 & 3 & 6 & língua/ tonsilas & PYA \\
\hline Abatedouro 1 & 4 & 6 & língua/ tonsilas & PYA \\
\hline Abatedouro 1 & 5 & 3 & língua/ tonsilas & PYA \\
\hline Abatedouro 1 & 5 & 8 & língua/ tonsilas & PYA \\
\hline
\end{tabular}


(conclusão)

\begin{tabular}{|c|c|c|c|c|}
\hline Local de origem & Coleta & $\mathrm{N}^{\circ}$ da amostra* & Tipo de amostra & Pulsotipo \\
\hline Abatedouro 1 & 8 & 12 & língua/ tonsilas & PYA \\
\hline Abatedouro 1 & 8 & 17 & língua/ tonsilas & PYA \\
\hline Abatedouro 1 & 9 & 2 & língua/ tonsilas & PYA \\
\hline Abatedouro 1 & 9 & 7 & língua/ tonsilas & PYA \\
\hline Abatedouro 1 & 9 & 12 & língua/ tonsilas & PYA \\
\hline Abatedouro 1 & 9 & 17 & língua/ tonsilas & PYA \\
\hline Abatedouro 1 & 9 & 20 & língua/ tonsilas & PYA \\
\hline Abatedouro 1 & 10 & 3 & língua/ tonsilas & PYA \\
\hline Abatedouro 1 & 10 & 11 & língua/ tonsilas & PYA \\
\hline Abatedouro 1 & 10 & 15 & língua/ tonsilas & PYA \\
\hline Abatedouro 1 & 10 & 17 & língua/ tonsilas & PYA \\
\hline Abatedouro 1 & 10 & 18 & língua/ tonsilas & PYA \\
\hline Abatedouro 1 & 11 & 2 & língua/ tonsilas & PYA \\
\hline Abatedouro 2 & 9 & 6 & língua/ tonsilas & PYA \\
\hline FCFRP & - & - & FCF 33 & PYA \\
\hline FCFRP & - & - & FCF 60 & PYA \\
\hline FCFRP & - & - & FCF 76 & PYA \\
\hline FCFRP & - & - & FCF 189 & PYA \\
\hline FCFRP & - & - & FCF 376 & PYA \\
\hline FCFRP & - & - & FCF 378 & PYA \\
\hline FCFRP & - & - & FCF 393 & PYA \\
\hline FCFRP & - & - & FCF 438 & PYA \\
\hline FCFRP & - & - & FCF 475 & PYA \\
\hline FIOCRUZ & - & - & IOC2143 (sangue -2005) & PYA \\
\hline FIOCRUZ & - & - & LBZ001/08 (bolsa de sangue) & PYA \\
\hline Abatedouro 1 & 12 & 1 & língua/ tonsilas & PYI \\
\hline Abatedouro 1 & 12 & 2 & língua/ tonsilas & PYI \\
\hline Abatedouro 1 & 12 & 6 & língua/ tonsilas & PYI \\
\hline Abatedouro 1 & 12 & 8 & língua/ tonsilas & PYI \\
\hline Abatedouro 2 & 5 & 4 & língua/ tonsilas & PYI \\
\hline Abatedouro 2 & 5 & 4 & língua/ tonsilas & PYI \\
\hline Abatedouro 2 & 5 & 8 & língua/ tonsilas & PYI \\
\hline Abatedouro 2 & 7 & 3 & língua/ tonsilas & PYI \\
\hline Abatedouro 2 & 7 & 4 & língua/ tonsilas & PYI \\
\hline Abatedouro 2 & 7 & 7 & língua/ tonsilas & PYI \\
\hline Abatedouro 2 & 10 & 9 & língua/ tonsilas & PYN \\
\hline Abatedouro 2 & 10 & 14 & língua/ tonsilas & PYN \\
\hline Abatedouro 2 & 10 & 18 & língua/ tonsilas & PYN \\
\hline Abatedouro 2 & 11 & 4 & língua/ tonsilas & PYO \\
\hline Abatedouro 2 & 11 & 6 & língua/ tonsilas & PYO \\
\hline Abatedouro 1 & 12 & 19 & língua/ tonsilas & PYO \\
\hline
\end{tabular}

*número 1 a 20 referente a qual amostra pertence o isolado (20 amostras por coleta, por local) - para abatedouros. 
DISCUSSÃO 


\section{DISCUSSÃO}

\subsection{LISTERIA MONOCYTOGENES}

Dois abatedouros foram analisados, durante um ano, para verificar a possível presença de L. monocytogenes em alguns de seus ambientes e nas línguas e tonsilas dos animais abatidos. Seguindo-se a linha de produção, carnes dos animais abatidos nestes locais foram analisadas em dois mercados que recebiam carcaças desses abatedouros, bem como seus ambientes. Todos os tipos de amostras coletadas apresentaram algum resultado positivo para L. monocytogenes.

Nos abatedouros, a média de amostras positivas de ambientes foi de $22,50 \%$ (27/120), sendo $28,33 \%$ (17/60) no abatedouro 1 , de baixa capacidade de abate diário (50 animais por hora), e 16,66\% (10/60) no abatedouro 2, de alta capacidade de abate diário (200 animais por hora). Esta taxa de contaminação é mais alta do que a encontrada por Chasseignaux et al. (2001), que foi de 11,66\% (7/60) de amostras positivas para L. monocytogenes em quatro meses de coleta, e por Sammarco et al. (1997) que foi de 4,0\% (7/175) de amostras positivas para Listeria spp, em nove meses de coletas em onze abatedouros, todos nos mesmos tipos de ambientes analisados no presente estudo - chão, parede e mesa. Em relação às amostras de línguas e tonsilas coletadas dos animais abatidos, apenas $1,66 \%$ $(4 / 240$ - e $0,83 \%$ do total - 4/480) delas, todas do abatedouro 1 , foram positivas para L. monocytogenes. Neste caso, os resultados aqui demonstrados são inferiores aos encontrados na literatura - 3,2 a 7,1\% (KANUGANTI et al., 2002), 13\% (AUTIO et al., 2000), 14\% (AUTIO et al., 2004) e 45\% (BUNČIĆ, 1991). Entretanto, os dados estão de acordo com resultado encontrado em estudo anterior realizado por esta mesma equipe, em quatro abatedouros do Estado de São Paulo (0\% - 0/124; PAIXÃO, 2006), o que pode sugerir uma possível diferença deste quadro no Brasil.

Quanto às amostras dos mercados, 18,05\% (13/72) em média de seus ambientes foram positivos para $L$. monocytogenes, sendo $19,44 \%$ (7/36) no mercado 1 e $16,66 \%$ (6/36) no mercado 2. Esta freqüência é semelhante, ou pouco inferior, à encontrada nos abatedouros estudados. Todavia, estes dados não podem ser comparados a outros de igual origem, já que não foram encontrados trabalhos 
específicos em mercados e açougues na literatura consultada. Sendo assim, podese apenas extrapolar para comparações com plantas maiores de processamento de carne suína - os dados aqui descritos são inferiores aos $37 \%$ encontrados por Chasseignaux et al. (2002) que analisaram três plantas de processamento pelo período de um a quatro meses; mas superiores aos $7 \%$ encontrados por Autio et al. (2000) que estudaram dez linhas de processamento.

Ainda nos mercados, as amostras de carne analisadas totalizaram $4,16 \%$ (5/120) de positivos para L. monocytogenes, sendo 3,33\% (2/60) no mercado 1 e $5,0 \%$ (3/60) no mercado 2, resultados estes, inferiores a quaisquer outros relatados na literatura - 11,8\% e 69\% em carne picada (SKOVGAARD; NØRRUNG, 1989; BUNČIĆ, 1991; respectivamente), 36\% em carne crua (CHASSEIGNAUX et al., 2001) e carne fatiada (IIDA et al., 1998) e 40 a 50,2\% em carne moída (KANUGANTI et al., 2002). O fato de ter sido encontrado valor tão inferior, pode ter ocorrido pelo tipo de amostra analisada neste estudo, em que fragmentos com aproximadamente $50 \mathrm{~g}$ que haviam sido retirados das carcaças recebidas pelos mercados foram picados no laboratório, com material estéril, e depois analisados (25 g para um cada dos agentes), ou seja, a área de contato com a superfície dos ambientes e equipamentos dos mercados foi bem menor do que a maioria dos tipos de carnes analisadas nos estudos descritos (fatiada, picada e moída).

Em relação aos sorotipos encontrados, no cômputo geral, todos os 348 isolados de $L$. monocytogenes foram sorotipados sendo detectados: 1/2c, 4b, 1/2b e $1 / 2 a$, em ordem decrescente de freqüência. Particularmente nos abatedouros, 0 predomínio foi de 1/2c, 1/2b, 4b e 1/2a, também em ordem decrescente. Este dado difere da maior ocorrência do sorotipo $1 / 2 a$, seguidos de $1 / 2$ c e $1 / 2 b$ descrito por Giovanacci et al. (1999), Chasseignaux et al. (2001) e Thévenot et al. (2005), bem como dos mais de $70 \%$ dos sorotipos $1 / 2$ a e $1 / 2 \mathrm{c}$ isolados de alimentos e seus ambientes de processamento descritos por Wagner e Allerberg (2003). Este achado pode ser característico da região pesquisada no presente estudo, mas está em parte, de acordo com os resultados obtidos por Keto-Timonen et al. (2007) que isolaram o sorotipo $1 / 2 \mathrm{c}$, além do $1 / 2 \mathrm{a}$, em todos os ambientes pesquisados, relatando sua maior capacidade de formação de biofilme e resistência aos desinfetantes utilizados; informação esta confirmada por Borucki et al. (2003) que também descrevem estes dois sorotipos como tendo maiores habilidades de formação de biofilmes. 
Segundo Lundén et al. (2000), alguns fatores podem explicar a alta prevalência do sorotipo 1/2c como: tipos de superfícies que facilitam a formação de biofilmes; prevalência do sorotipo 1/2c, com maior número de células, facilitando seu isolamento em detrimento dos outros sorotipos; diferenças de seu antígeno flagelar em relação aos outros sorotipos, levando a um maior efeito na iniciação da aderência à superfície; e, possivelmente, a persistência do isolados.

A freqüência dos sorotipos nos mercados revela outra situação. Nestes, o sorotipo $4 \mathrm{~b}$ foi o predominante, inclusive em ambientes, seguido de $1 / 2 \mathrm{c}, 1 / 2 \mathrm{~b}$ e 1/2a. Estes dados também podem ser comparados apenas a dados obtidos de pesquisas em plantas de processamento de carne suína, e não em mercados ou açougues. Visto isso, o resultado aqui demonstrado é oposto ao indicado por Jay (1996) que diz serem os sorotipos $1 / 2 a, 1 / 2 c$ e $1 / 2 b$ os mais encontrados em produtos de carne suína processada, enquanto o sorotipo $4 \mathrm{~b}$ é raro. Entretanto, Thévenot et al. (2006) obtiveram vários isolados do sorotipo 4b em duas diferentes fábricas de cura de produtos suínos, com o mesmo perfil de PFGE do isolado padrão utilizado, demonstrando que a prevalência dos sorotipos $4 \mathrm{~b}$ e 1/2b tende a aumentar após o processamento, enquanto a prevalência de $1 / 2$ a $1 / 2$ c tende a diminuir, como encontrado no presente estudo.

Ao serem analisadas em separado, as linhas 1 e 2 (abatedouro e mercado 1; abatedouro e mercado 2; respectivamente) de produção de carne de suínos estudadas, e juntamente com a análise da PFGE, pode-se observar mais claramente o que ocorre.

Na linha 1, no abatedouro, com capacidade para abater 50 animais por hora, $82,14 \%(23 / 28)$ dos isolados de língua e tonsilas e $97,36 \%(111 / 114)$ dos isolados de ambientes contaminados são do sorotipo 1/2c, o que pode sugerir a entrada do agente através do animal e a posterior contaminação do ambiente com formação de biofilme. Através da análise de PFGE, todos os isolados do sorotipo $1 / 2 \mathrm{c}$ pertencem a um mesmo pulsotipo (PLB - perfil predominante neste estudo), inclusive dos mesmos ambientes em coletas diferentes, com até oito meses de diferença juntamente com os isolados de língua e tonsilas do sorotipo $1 / 2 b$ - confirmando as suspeitas de que podem ser formadores de biofilmes no local, assim como descrito por Thévenot et al. (2006) que encontraram isolados do sorotipo $1 / 2 c$ indistinguíveis geneticamente, sugerindo que a linhagem pode ser muito jovem, que pode ter havido forte pressão seletiva ou ambos. Seguindo esta linha até o mercado, $72 \%$ 
(18/25) dos isolados de L. monocytogenes de carne são do sorotipo 1/2c, podendo indicar contaminação da carcaça na linha do abate por meio do ambiente (os isolados do sorotipo $1 / 2 \mathrm{c}$ de língua e tonsilas e carnes não foram analisados pela PFGE); já os outros $28 \%$ (7/25) são do sorotipo 4b, que é predominante no ambiente deste mercado (70,1\% - 37/48), sugerindo contaminação das carnes no local, o que foi confirmado pela PFGE, que demonstrou o mesmo perfil na carne e no ambiente (PLD) além de isolados de ambientes com perfis idênticos em diferentes meses de coletas, podendo indicar também a persistência destes isolados.

A análise da linha 2, onde o abatedouro tem capacidade para abater 200 animais por hora, é um pouco diferente. Nele não foi encontrada presença de $L$. monocytogenes nas línguas e tonsilas, fato que pode ter permitido que diversos sorotipos contaminassem o ambiente, sendo os sorotipos mais freqüentes nos ambientes, 1/2c (62,3\% - 38/61) e 1/2b (27,87\% - 17/61), mas também com presença de $1 / 2$ a e $4 b$, o que é confirmado pela variedade de pulsotipos encontrada, não parecendo haver persistência de isolados como no abatedouro 1. No mercado, as carnes apresentaram quase que exclusivamente o sorotipo 4b (94,45\% - 17/18), que foi também o sorotipo mais freqüente em seus ambientes (42,60\% - 23/54), além do sorotipo 1/2b. Em ambos os casos, a similaridade dos pulsotipos encontrados dentro de um mesmo sorotipo nas carnes e nos ambientes, de abatedouro ou mercado, foi muito alta, próxima de 90\% (PLF e PLH; PLO e PLR, respectivamente).

Em relação às linhagens, isolados de $L$. monocytogenes são divididos em três linhagens genéticas, onde a linhagem I consiste dos sorotipos $1 / 2 b, 4 b, 3 b, 4 d$ e $4 e$, a linhagem II dos sorotipos 1/2a, 1/2c, 3a e 3c, e a linhagem III dos sorotipos $4 \mathrm{a}$ e 4c. O dendrograma gerado dividiu os isolados em duas diferentes linhagens: I e II, normalmente onde se situam os isolados de casos esporádicos e de surtos (Liu, 2006), havendo quatro clusters formados com mais de $80 \%$ de similaridades entre os isolados: A, B e C, na linhagem I, e D, na linhagem II. Na linhagem I estão os sorotipos $1 / 2 b$ e $4 b$ isolados de carnes e dos ambientes dos mercados e seis dos dez isolados de casos clínicos de humanos, com exceção de três isolados $1 / 2 a$ de mercado (PLM e PLP) e cinco isolados, que apesar de serem 1/2b são de abatedouro (PLO, PLN e PLF); já na linhagem II estão os sorotipos 1/2a e 1/2c isolados de ambientes de abatedouros e os isolados $1 / 2 a$ de casos clínicos de humanos, além de quatro isolados, que apesar de serem de abatedouro, inclusive 
de língua e tonsilas, são dos sorotipos 4b e 1/2b (PLB e PLQ). Esta não separação exata nas linhagens não é comum de se encontrar na literatura, mas pode ocorrer, assim como no trabalho de Dauphin, Ragimbeau e Malle (2001) onde isolados dos sorotipos $1 / 2 b$ e $4 b$ se agruparam com isolados dos sorotipos $1 / 2 a$ e $1 / 2 c$, em plantas de processamento de salmão. Outros trabalhos relatam a presença de isolados sorotipados como $4 \mathrm{~b}$ na linhagem III, mas a realização de técnicas moleculares os mostraram como 4c e 4a (LIU, 2006).

Assim sendo, a divisão obtida está de acordo com dados que sugerem que a linhagem II é mais prevalente no início da linha de processamento, ou seja, no abatedouro, e a linhagem I aumenta quando aumenta o processamento do alimento, ou seja, nos mercados (THÉVENOT et al., 2006). Talvez seja essa a explicação para o maior envolvimento dos sorotipos $4 \mathrm{~b}$ e $1 / 2 \mathrm{~b}$ em casos em humanos, assim com também demonstram os dados gerados pela comparação de isolados do presente estudo e de isolados de casos clínicos de humanos de diferentes sorotipos, origens e anos. A comparação os colocou em suas linhagens específicas: os sorotipos 1/2a na linhagem II e os sorotipos $1 / 2 b$ e $4 b$ na linhagem I. Interessante é que, apesar de muitos desses isolados serem de casos clínicos de até 30 anos atrás, pulsotipos idênticos ou muito similares a eles foram detectados nos dias atuais em mercados e abatedouros, como demonstram os pulsotipos: PLJ, PLT, PLA, PLE e PLF, o que pode sugerir a persistência por anos destes pulsotipos ou sua maior distribuição em ambientes. Neste caso, pode-se sugerir a PFGE como ferramenta epidemiológica em surtos de listeriose e para traçar a contaminação por L. monocytogenes em linhas de processamento na cadeia suinícola.

Por fim, o estudo revelou a presença de L. monocytogenes de sorotipos patogênicos em animais e ambientes de abatedouros, bem como em carnes e ambientes de mercados, indicando que algumas medidas devem ser tomadas para se evitar problemas com surtos ou casos esporádicos de listeriose, visto que algumas condições encontradas pelo agente, na cadeia de produção e conservação da carne suína, como temperatura $\left(0,4\right.$ a $\left.45^{\circ} \mathrm{C}\right), \mathrm{pH}(4,6$ a 9,6), concentração de $\mathrm{NaCl}$ (até acima de 10\%) e atividade de água $(0,92)$, favorecem o seu crescimento, através da cadeia do frio desde o abatedouro até as residências dos consumidores. Entretanto, o único ponto específico para controle da contaminação dá-se nos procedimentos e produtos de limpeza e desinfecção dos ambientes e equipamentos 
utilizados para manipulação da carne com o objetivo de remover as substâncias orgânicas e de se evitar a formação de biofilmes (THÉVENOT et al., 2006).

Primeiramente, um passo muito importante, é a realização da remoção mecânica da matéria orgânica presente nas superfícies, já que esta favorece a fixação do agente e evita o contato do desinfetante com o mesmo; além disso, esse é o passo mais efetivo para se desafixar as células aderidas e os biofilmes em linhas de processamento já contaminadas com isolados persistentes, embora nesses casos seja difícil a erradicação do agente. Em seguida, dever ser feita a limpeza com detergente, geralmente alcalino, para remover os resíduos da matéria orgânica, sendo então retirados com lavagem. O segundo grande passo é a desinfecção, que só será efetiva se o primeiro passo for adequadamente realizado. A escolha do desinfetante é crucial, já que deve ter atividade bactericida e ser eficaz contra os agentes existentes em cada local (THÉVENOT et al., 2006). Normalmente o produto de escolha são os compostos de amônia quaternária, devido a sua propriedade biocida combinado com o fato de não ser tóxica, não ser corrosiva e não gerar manchas, tanto para as superfícies quanto para a pele humana. Todavia, mesmo com a concentração inibitória mínima sendo utilizada, há o aumento dos isolados com resistência a este desinfetante, fato de mecanismos ainda não esclarecidos, mas que segundo Romanova, Favrin e Griffiths (2002) é conferida por um gene de transmissão plasmidial e um cromossomal, e segundo Holah et al. (2002) ocorre devido a mecanismos físicos de adaptação (fixação à superfície, formação de biofilme, taxa reduzida de crescimento bacteriano e quiescência). Porém, deve-se lembrar que o tipo de superfície também deve ser levado em consideração (aço inoxidável, ferro, plástico, dentre outras) que pode ter limitada penetração do produto escolhido (BREMER; MONK; BUTLER, 2002). Pelos estudos realizados por Vasseur et al. (2001) o tratamento mais eficiente para L. monocytogenes foi uma combinação de choques alcalino, osmótico e biocida; já Mereghetti et al. (2000) sugerem a rotação de desinfetantes para prevenir ou prolongar o desenvolvimento de resistência; mas seja qual for o procedimento a ser seguido, ele deve ser realizado diariamente (NORWOOD; GILMOUR, 2000), para que isolados persistentes e não persistentes possam ser eliminados. Além disso, tão importante quanto o já exposto é a adoção de medidas de boas práticas de higiene e de boas práticas de fabricação que ajudarão a limitar o risco de disseminação de patógenos transmitidos por alimentos, incluindo L. monocytogenes, e a análise de perigos e pontos críticos de 
controle (HACCP) que também deveria ser aplicada a cada planta de processamento a fim de se identificar e controlar as fontes de contaminação e disseminação antes de qualquer decisão. 


\subsection{YERSINIA ENTEROCOLITICA}

Dois abatedouros foram analisados, durante um ano, para verificar a possível presença de $Y$. enterocolitica 4/ 0:3 - bio-sorotipo patogênico para humanos - em alguns de seus ambientes e nas línguas e tonsilas de animais abatidos. Seguindo-se a linha de produção, carnes de animais abatidos nestes locais foram analisados em dois mercados correspondentes, bem como em seus ambientes. Apenas amostras de línguas e tonsilas de ambos os abatedouros e amostras de ambientes do abatedouro 1 apresentaram resultado positivo para $Y$. enterocolitica 4/ 0:3; além disso, todos os locais amostrados foram positivos para $Y$. enterocolitica biotipo $1 \mathrm{~A}$, de diversos sorotipos, considerada não patogênica - fato a ser discutido mais a frente neste tópico.

Em relação às amostras de línguas e tonsilas coletadas, a média de positivos para Y. enterocolitica $4 / 0: 3$ foi de $30 \%$ (144/480), sendo 33,33\% (80/240) das amostras positivas no abatedouro 1 e 26,67\% (64/240) no abatedouro 2. Neste caso, os resultados aqui demonstrados são muito inferiores aos $83,3 \%$ (25/30) demonstrados por Nesbakken (1988) na Noruega, embora sua amostragem tenha sido muito inferior, e aos 60\% (30/50) de Fredriksson-Ahomaa et al. (2001a) na Alemanha. Entretanto, são similares ou pouco inferiores a maioria dos encontrados na literatura - 34\% de tonsilas em abatedouro na Suíça (FREDRIKSSON-AHOMAA; STOLLE; STEPHAN, 2007); 38,4\% (GÜRTLER et al., 2005) e 28,8\% (NOWAK et al., 2006) na Alemanha; 38,3\% e 31,3\% em dois abatedouros na Finlândia (ASPLUND et al., 1990); 42\% de tonsilas e 20\% de línguas na Holanda (BOER; NOUWS, 1991). Esta pequena diferença pode ser devido ao fato dos dados relatados por esses autores englobarem todos os bio-sorotipos de $Y$. enterocolitica isolados e não apenas do 4/ O:3, embora quase todos os seus isolados tenham sido bio-sorotipo 4/ 0:3. Outro fator muito importante é citado por Kapperud (1991), que diz que o agente é mais freqüentemente isolado em países de climas frios, fator que poderia favorecer a sobrevivência do mesmo nos países dos estudos acima citados. Porém, ele também relata que pouco é conhecido sobre a incidência da $Y$. enterocolitica em suínos em países tropicais, como é o caso do Brasil, o que reforça a importância do presente estudo. Dado este fato, a grande diferença na prevalência obtida em alguns dos estudos pode ocorrer de acordo com a época em que foram 
coletadas as amostras nesses países (geralmente de poucos meses), já que é descrita a sua maior prevalência nos meses de inverno (WEBER; KNAPP, 1981). Isto não foi constatado no presente estudo, exceto por não haver isolamento nas duas primeiras coletas realizadas, correspondentes aos meses de maio e junho, e uma menor quantidade também na última coleta, realizada em abril, quando são abatidos suínos que vivem durante os meses mais quentes do ano, no verão, o que pode ter dificultado a sobrevivência do agente e a ausência do isolamento. Avaliouse a hipótese de realizar uma análise embasada nesta possibilidade através de gráficos de variação de temperatura nos locais em que foram criados os animais analisados, mas isto não foi possível devido à ausência de estações meteorológicas nas cidades em questão ou próximas a elas (segundo informações fornecidas, via email, por um funcionário do INMET - Instituto Nacional de Meteorologia).

Apenas o abatedouro 1 apresentou ambientes positivos totalizando 3,33\% (2/60 - chão e parede da sala de abate; $1,66 \%$ do total de ambientes de abatedouros - 2/120) de seu total de ambientes. Já o abatedouro 2 não apresentou qualquer isolado positivo para $Y$. enterocolitica 4/ O:3. Esta taxa de contaminação é bem menor do que a encontrada por Nesbakken (1988) que foi de $80 \%(4 / 5)$, sugerindo que o sangue e a água de lavagem contaminados com $Y$. enterocolitica 4/ O:3 podem contaminar o chão; e igualmente inferior aos 28,5\% (2/7) de amostras de piso positivas analisadas por PCR para $Y$. enterocolitica patogênica, descrito por Fredriksson-Ahomaa, Korte e Korkeala (2000). O motivo para a baixa contaminação de pisos talvez seja a presença de $Y$. enterocolitica não patogênica, que formaria um biofilme persistindo no ambiente e inibindo a instalação da $Y$. enterocolitica patogênica, ou por competição com outros microorganismos formadores de biofilme.

Quanto às amostras dos dois mercados, nenhuma das amostras de ambientes ou de carnes analisadas foram positivas para $Y$. enterocolitica 4/ 0:3, apresentando apenas isolamento de $Y$. enterocolitica 1A não patogênica. De acordo com Asplund et al. (1990), nenhuma amostra positiva foi detectada no total de 104 carnes analisadas - inteira e picada - em açougues em Helsinki, na Finlândia, o que, neste caso, pode ter ocorrido devido ao processo de remoção das tonsilas durante o abate, que acontece apenas ao final da linha, diminuindo a contaminação da carne; todavia, este tipo de procedimento não ocorre nos abatedouros estudados e, de modo geral, em abatedouros no Brasil; entretanto, segundo Lambertz e 
Danielsson-Tham (2005), em seus estudos e outros relatados na literatura, é muito difícil isolar $Y$. enterocolitica patogênica de alimentos. Já outros autores detectaram a presença do agente patogênico em carne com freqüência variando de 1 a $30 \%$, sendo: $30 \%$ em carne de suíno - Y. enterocolitica 4/ 0:3 e outras $1 \mathrm{~A}$ - no Canadá (TOORA et al., 1994); 1,0\% em carne suína picada (BOER; NOUWS, 1991); 20,7\% em carne suína moída (carne de cabeça e tecido tonsilar - TAUXE et al., 1987); $12 \%$ em carne suína e $1 \%$ em ambiente de mercado (mesa - FREDRIKSSONAHOMAA et al., 2004). Esta variação de freqüência existente pode explicar o fato de não ser detectado o agente patogênico em carnes do estudo realizado, aliado também a mais elevada temperatura ambiental, por ser o Brasil um país tropical de que não se conhece muito a respeito do agente em questão, e ao fato de uma possível competição entre $Y$. enterocolitica $1 A$, não patogênica, ou mesmo com outros gêneros de bactérias na contaminação de ambientes e carnes.

Os 444 isolados de $Y$. enterocolitica foram caracterizados fenotipicamente sendo detectados: 72,08\% (320/444) de 4/ 0:3; 20,72\% (92/444) de 1A/ não tipável; 2,25\% (10/444) de 1A/ O:5a; 4,06\% (18/444) de 1A/ O:5b; 0,22\% (1/444) de 1A/ O:7; $0,22 \%(1 / 444)$ de $1 \mathrm{~A} / 0: 6$ e 0,45\% (2/444) de rugosa, o que demonstra grande prevalência do agente patogênico nos locais estudados.

Das 320 amostras de $Y$. enterocolitica 4/ 0:3, 95,94\% (307/320) apresentaram o gene ail; $100 \%$ o gene yst e 83,44\% (267/320) o gene virF; dados muito similares aos encontrados por Falcão et al. (2006), que obtiveram $100 \%$ de amostras 4/ 0:3 com presença do gene ail e yst, mas com porcentagem pouco menor de gene virF, que foi de 61,8\%, em isolados de fezes de várias espécies animais. A maior porcentagem com gene virF no presente estudo pode ser devido ao fato dos isolados aqui analisados pertencerem apenas a suínos.

As yersinias do biotipo $1 \mathrm{~A}$ são consideradas não patogênicas, não têm plasmídeo, mas crescem as evidências experimentais, epidemiológicas e clínicas que sugerem que algumas são virulentas e podem causar doença gastrointestinal; a partir de então, vários pesquisadores começaram a investigar a presença de genes de virulência nesse biotipo, através da PCR (FREDRIKSSON-AHOMAA; STOLLE; KORKEALA, 2006). Na investigação realizada pelo presente estudo, os isolados do biotipo $1 \mathrm{~A}$ apresentaram alguns fatores de virulência, assim como alguns isolados de animais e ambiente no Brasil, como descrito por Falcão e Falcão (2006) e Falcão et al. (2006). 
Os 122 isolados do biotipo $1 \mathrm{~A}$, assim como os demais, foram caracterizados pela PCR por uso de um multiplex e foram obtidos diversos padrões, a maioria não compatível com isolados não patogênicos por apresentarem genes ail, virF e yst. A presença do gene ail, gene cromossomal que codifica uma proteína que capacita a invasão e o estabelecimento do agente no hospedeiro suscetível, designado como ausente em isolados não patogênicos, foi detectada em 61,48\% (75/122) dos isolados de biotipo 1A. Outro gene cromossomal, o yst, responsável pela produção de uma enterotoxina termoestável, envolvida em casos de gastroenterite, inicialmente ausente em não patogênicos, foi detectado em 59,84\% (73/122) desses mesmos isolados, sendo que existe um gene antigenicamente relacionado que expressa uma enterotoxina termoestável diferenciada neste biotipo, denominada Yst II, já relatado na literatura (ROBINS-BROWNE et al., 1993). Além desses dois genes, um gene plasmidial, virF, que codifica uma proteína que é a principal reguladora do aparato de patogenicidade, está presente em 71,31\% (87/122) dos isolados de biotipo 1A. Estes achados são muito superiores aos encontrados por outro grupo de pesquisadores do Brasil, que encontrou $5,7 \%$ dos isolados contendo o gene ail, 5,7\% o gene ystA e 2,9\% o gene virF, em $Y$. enterocolitica de alguns biosorotipos diferentes de $4 /$ O:3, isoladas de alimentos (FALCÃO et al., 2006). Isto pode ter ocorrido devido à diferença nos tipos de amostras analisadas entre os dois grupos - Falcão et al. (2006) analisaram fezes de humanos e animais, e alimentos cárneos de várias espécies animais, bem como produtos lácteos; e o grupo do presente estudo analisou especificamente amostras de carne suína e ambientes de abatedouros exclusivo de suínos e mercados apenas de produtos cárneos, o que pode demonstrar a maior porcentagem de positivos com potencial patogênico por se tratar de um estudo relacionado a suínos, que é a espécie suspeita de envolvimento com a doença em humanos.

Estes dados não são geralmente esperados, mas confirmam alguns relatos da literatura. Ratnam et al. (1982) isolaram Y. enterocolitica 1A/ 0:5 de um surto hospitalar de diarréia em nove pacientes - neonatos e idosos, mas somente após enriquecimento seletivo das amostras, e sem detecção de plasmídeos nos isolados, confirmando que isolados geralmente não patogênicos são capazes de causar doença em raras ocasiões, concordando com Weissfeld e Sonnenwirth (1980) que isolaram o mesmo bio-sorotipo, após crio-enriquecimento de 21 dias. Outro biosorotipo o biotipo $1 \mathrm{~A} / 0: 6,30$, também foi responsável por causar gastroenterite em 
duas mulheres idosas, como relatado por Mclntyre e Nnochiri (1986), indicando a capacidade do bio-sorotipo "inócuo" produzir doença em hospedeiros imunossuprimidos. Outro estudo relata que a gastroenterite causada pelo biotipo $1 \mathrm{~A}$ é indistinguível daquelas causadas por biotipos patogênicos primários, após a confirmação da presença do gene yst em $77,7 \%$ das amostras clínicas analisadas e em $62,3 \%$ das amostras de suínos, concluindo ainda que o gene está amplamente distribuído no biotipo 1A, com produção induzida por condições de pH encontradas em íleo, sugerindo sua importância como fator de virulência neste biotipo (SINGH; VIRDI , 2004). Além disso, um estudo recente que analisou diferentes biotipos de $Y$. enterocolitica isolados de humanos e animais, sugere que alguns isolados do biotipo $1 \mathrm{~A}$, classicamente definidos como não patogênicos, aderem, invadem e persistem em macrófagos e são estreitamente relacionados aos biotipos 3 e 4 , diferindo apenas pela resposta inflamatória dos macrófagos infectados do hospedeiro (MCNALLY et al., 2006), demonstrando, mais uma vez, a capacidade de patogenicidade deste biotipo, que deve ser estudado mais profundamente.

Em relação ao gene rfbC, para detectar o sorogrupo $0: 3,80,33 \%$ (98/122) dos isolados de $Y$. enterocolitica $1 \mathrm{~A}$ foram positivos, o que teoricamente não deveria acontecer. Entretanto, o estudo em que o primer foi desenvolvido e testado, utilizou isolados de outras espécies de Yersinia e apenas 15 de $Y$. enterocolitica para validálo, sendo quatro delas do sorotipo $0: 3$, o que é considerado um número muito pequeno (WEYNANTS et al., 1996). No presente estudo, 444 isolados foram testados com o primer em questão, e dos 320 isolados do bio-sorotipo 4/ 0:3, sete $(2,19 \%)$ foram negativos para o gene, o que pode revelar uma falha no primer desenvolvido (fato a ser investigado em pesquisa futura).

Quanto à PFGE, sua análise gerou 15 diferentes pulsotipos - PYA a PYP sendo PYA e PYB predominantes e compreendendo mais de $50 \%$ dos isolados analisados, inclusive os isolados de casos clínicos em humanos (onze do total de doze analisados pertencentes a PYA). Os isolados foram considerados diferentes quando ao menos uma banda diferente foi encontrada entre dois perfis, devido à variação genética da $Y$. enterocolitica 4/ 0:3 ser limitada, os genótipos mostrarem-se estáveis in vitro e as mesmas regras de diferenças de bandas serem usadas para diferenciar isolados de $Y$. enterocolitica em muitos estudos já realizados (FREDRIKSSON-AHOMAA et al., 2001b). Este fato está de acordo com os encontrados neste estudo, onde a variação do padrão de bandas foi mínima, com 
similaridade entre eles de $89 \%$ ou mais, havendo maior biodiversidade entre isolados de origem suína do que em isolados de origem humana e não havendo nenhum agrupamento de amostras no que diz respeito à origem dos isolados obtidos, exceto os isolados de origem humana, que se agruparam em um mesmo pulsotipo com isolados de abatedouros. Segundo Fredriksson-Ahomaa et al. (2001b), outros pulsotipos que não humanos podem pertencer a isolados menos virulentos que causam somente infecções mais brandas e que necessitam de alta dose infectante. A homogeneidade global de pulsotipos de isolados de $Y$. enterocolitica 4/ O:3 é alta, mas o uso da digestão com as enzimas Apal e Xhol, posteriormente à caracterização com Notl, pode diferenciar eficientemente este biosorotipo em vários pulsotipos, podendo assim ser a PFGE utilizada como ferramenta para estudos epidemiológicos, como por exemplo a sua diferenciação de acordo com a localização geográfica (FREDRIKSSON-AHOMAA et al., 2003; FREDRIKSSON-AHOMAA; STOLLE; KORKEALA, 2006).

Em relação aos pulsotipos gerados pela PFGE realizada com os isolados do bio-sorotipo $1 \mathrm{~A}$, houve grande diversidade, com praticamente um pulsotipo gerado por isolado analisado, sendo estes claramente diferenciados dos isolados do biosorotipo 4/ 0:3. Com este resultado pode-se distinguir isolados pertencentes ao biosorotipo 4/ 0:3 de outros grupos associados com patogenicidade ou não, o que implica na utilização da PFGE, apenas com a restrição pela enzima Notl, como uma valiosa ferramenta de tipagem de isolados de $Y$. enterocolitica ou sua confirmação após testes bioquímicos e sorológicos, e não apenas para análises epidemiológicas (LAMBERTZ; DANIELSSON-THAM, 2005; FREDRIKSSON-AHOMAA; STOLLE; KORKEALA, 2006).

Para concluir, estudos relatam os suínos como portadores da $Y$. enterocolitica 4/ 0:3 desde a criação, estando o agente presente em suas tonsilas a partir dos 80 dias de idade, o que as torna a principal fonte de contaminação, mas excluindo sua transmissão durante o transporte dos animais aos abatedouros e durante sua permanência nas baias de espera (NESBAKKEN et al., 2006). Já nos abatedouros, as tonsilas podem contaminar carcaças, órgãos e ambientes, levando à disseminação do agente tanto nos abatedouros quanto posteriormente nos mercados e carnes, principalmente quando se leva em consideração o fato do agente ser psicotrófico, permanecendo na cadeia do frio do abatedouro até o refrigerador dos consumidores. Dados de estudos caso-controle relatam forte 
associação entre a yersiniose e o consumo de carne suína crua ou mal cozida, e que a contaminação cruzada na manipulação de alimentos por equipamentos contaminados também pode ocorrer, sendo esta a via de infecção mais provável da doença. Desta forma, os pontos críticos de controle estão na remoção da língua e tonsilas durante o abate, que deveria ser realizada, antes da evisceração, juntamente com a remoção da cabeça, para evitar a disseminação do agente pelo ambiente; além disso, elas devem ser analisadas em salas separadas dos demais órgãos (FREDRIKSSON-AHOMAA et al., 2001a). Apesar de as amostras de línguas e tonsilas deste estudo estarem contaminadas com $Y$. enterocolitica 4/ 0:3, não houve seu isolamento de carnes e ambientes de mercados, apenas de ambientes de abatedouro, e o problema não parece aparente; entretanto há possibilidade de contaminação, e outros estudos deveriam ser realizados para uma melhor avaliação desta situação em nosso país. Além disso, e tão importante quanto, a presença de yersinias do biotipo $1 \mathrm{~A}$ com genes codificadores de fatores de virulência em amostras de carne e ambientes neste estudo, remete à necessidade de maiores investigações sobre estes isolados, avaliando a real probabilidade dos mesmos infectarem os seres humanos. Sendo assim, medidas de boas práticas de manipulação devem ser seguidas principalmente nos mercados e pelos consumidores, em suas residências, a fim de se minimizar o espalhamento desses agentes possivelmente patogênicos. 
CONCLUSÕES 


\section{CONCLUSÕES}

\subsection{LISTERIA MONOCYTOGENES}

* Todos os tipos de amostras analisadas (língua e tonsilas, carnes e ambientes de abatedouros e mercados) apresentaram resultado positivo para Listeria monocytogenes.

* Os sorotipos dos isolados obtidos são patogênicos para humanos, sendo o principal deles, o sorotipo $4 \mathrm{~b}$, encontrado com grande freqüência nos mercados, ou seja, mais próximo dos consumidores, no que diz respeito à cadeia produtiva, fato este que aumenta as chances de infecção em humanos.

* Os isolados patogênicos encontrados persistem nos ambientes, inclusive em mercados, tendo sido também demonstrada a possibilidade de contaminação das carnes manipuladas no local.

* Os isolados de casos clínicos em humanos, apesar da grande diferença de épocas de isolamento (até 30 anos), apresentaram pulsotipos idênticos ou muito similares àqueles detectados nos isolados atuais de abatedouros e mercados.

Há necessidade de se adotar intervenções nos abatedouros e, principalmente, nos mercados, a fim de se evitar a contaminação de carnes e a posterior infecção de humanos, através da introdução e acompanhamento de procedimentos e produtos de limpeza e desinfecção adequados aos ambientes e equipamentos utilizados para manipulação da carne, bem como a adoção de medidas de boas práticas de higiene e fabricação para evitar o risco da disseminação do agente. 
Apenas amostras de língua e tonsilas, de ambos os abatedouros, e amostras de ambiente de um dos abatedouros, apresentaram resultado positivo para Yersinia enterocolitica 4/ 0:3, o bio-sorotipo patogênico para humanos.

* Os isolados de Yersinia enterocolitica 4/ 0:3 apresentaram fatores de virulência e tiveram grande similaridade em seus pulsotipos, inclusive aqueles isolados de casos clínicos em humanos.

* Devido a baixa freqüência de isolamento de Yersinia enterocolitica 4/ 0:3 em ambientes e carne, este agente parece apresentar menor risco de transmissão aos humanos nos locais analisados.

* Todos os tipos de amostras analisadas apresentaram resultado positivo para Yersinia enterocolitica 1A geralmente considerada não patogênica.

A grande maioria dos isolados de Yersinia enterocolitica 1A também apresentou fatores de virulência, o que sugere a possibilidade de que estas cepas sejam patogênicas para humanos, fato a ser melhor estudado nestas amostras.

- Medidas de boas práticas de fabricação e manipulação devem ser seguidas, a fim de se minimizar a contaminação de produtos de origem suína por Yersinia enterocolitica $1 \mathrm{~A}$, possivelmente patogênicas 
REFERÊNCIAS 


\section{REFERÊNCIAS}

ALBUQUERQUE, M. C. B.; CARDOSO, M. Pesquisa de Yersinia enterocolitica em lingüiças frescas de porco em Porto Alegre, RS. Ciênc. Rur., v. 29, n. 4, p. 727-9, 1999.

ALEKSIC, S.; STEIGERWALT, A. G.; BOCKEMÜHL, J.; HUNTLE-CARTER, G. P.; BRENNER, D. J. Yersinia rohdei sp. nov. isolated from human and dog feces and surface water. Int. J. Syst. Bacteriol., v. 37, p. 327-32, 1987.

ANDERSEN, J. K. Contamination of freshly slaughtered pig carcasses with human pathogenic Yersinia enterocolitica. Int. J. Food Microbiol., v. 7, p. 193-202, 1988.

ASPLUND, K.; TUOVINEN, V.; VEIJALAINEN, P.; HIRN, J. The prevalence of Yersinia enterocolitica O:3 in Finnish pigs and pork. Acta Vet. Scand., v. 31, p. 3943, 1990.

AUTIO, T.; MARKKULA, A.; HELLSTRÖM, S.; NISKANEN, T.; LUNDÉN, J.; KORKEALA, $\mathrm{H}$. Prevalence and genetic diversity of Listeria monocytogenes in the tonsils of pigs. J. Food Prot., v. 67, n. 4, p. 805-8, 2004.

AUTIO, T.; SÂTERI, T.; FREDRIKSSON-AHOMAA, M.; RAHKIO, M.; LUNDÉN, J.; KORKEALA, H. Listeria monocytogenes contamination pattern in pig slaughterhouse. J. F. Prot., v. 63, n. 10, p. 1438-42, 2000.

AZADIAN, B. S.; FINNERTY, G. T.; PEARSON, A. D. Cheese-borne Listeria meningitis in immunocompetent patient. Lancet, v. 1, p.322-3, 1989.

AZNAR, R.; ALARCON, B. On the specificity of PCR detection of Listeria monocytogenes in food: a comparison of published primers. Syst. Appl. Microbiol., v. 25, p. 109-19, 2002.

BATT, C. Molecular diagnostics for dairy-borne pathogens. J. Dairy Science, v. 80, p. 220-9, 1997.

BAUWENS, L.; VERCAMMEN, F.; HERTSENS, A. Detection of pathogenic Listeria spp. in zoo animal faeces: use of immunomagnetic separation and a chromogenic isolation medium. Vet. Microbiol., v. 91, p. 115-23, 2003. 
BELOEIL, P.A.; FRAVALO, P.; CHAUVIN, C.; FABLET, C.; SALVAT, G.; MADEC, F. Listeria spp. contamination in piggeries: Comparison of three sites of environmental swabbing for detection and risk factor hypothesis. J. Vet. Med., v. 50, p. 155-60, 2003.

BERCOVIER, H.; STEIGERWALT, A. G.; GUIYOULE, G.; HUNTLE-CARTER, G. P.; BRENNER, D. J. Yersinia aldovae (formerly Yersinia enterocolitica-like group X2): a new species of Enterobacteriaceae isolated from aquatic ecosystem. Int. J. Syst. Bacteriol., v. 34, p. 1166-72, 1984.

BERCOVIER, H.; URSING, J.; BRENNER, D. J.; STEIGERWALT, A. G.; FANNING, G. R.; CARTER, G. P.; MOLLARD, H. H. Yersinia kristensenii: a new species of Enterobacteriaceae composed of sucrose-negative strains (formerly called atypical Yersinia enterocolitica or Yersinia enterocolitica-like). Curr. Microbiol., v. 4, p. 21924, 1980.

BESSESEN, M. T.; LUO, Q.; ROTBART, H. A.; BLASER, M. J.; ELLISON III, R. T. Detection of Listeria monocytogenes by using the polymerase chain reaction. Appl. Environ. Microbiol., v. 56, p. 2930-2, 1990.

BEUSCHER, H. R.; RODEL, F.; FORSBERG, A.; ROLLINGHOFF, M. Bacterial evasion of host immune response: Yersinia enterocolitica encodes a suppressor for tumor necrosis factor alpha expression. Infect. Immun., v. 63, p. 1270-7, 1995.

BOER, E.; NOUWS, J. F. M. Slaughter pigs and pork as a source of human pathogenic Yersinia enterocolitica. Int. J. Food Microbiol., v. 12, p. 375-8, 1991.

BONARDI, S.; BRINDANI, F.; MAGGI, E. Isolation of Listeria monocytogenes and Listeria spp. from pigs at slaughter in Italy. Ann. Fac. Vet. Di Parma, v. 22, p. 20510, 2002.

BOOM, R.; SOL, C.J.A.; SALIMANS, M.M.M. Rapid and simple method for purification of nucleic acids. J. Clin. Microbiol., v. 28, p. 459-3. 1990.

BORDER, P. M.; HOWARD, J. J.; PLASTROW, G. S.; SIGGENS, K. W. Detection of Listeria species and Listeria monocytogenes using polymerase chain reaction. Lett. Appl. Microbiol., v. 11, p. 158- 62, 1990.

BORGES, M. F.; SIQUEIRA, R. S.; BITTENCOURT, A. M.; VANETTI, M. C. D.; GOMIDE, L. A. M. Occurrence of Listeria monocytogenes in salami. Rev. Microbiol., v. 30, p. 362-4, 1999. 
BORUCKI, M. K.; CALL, D. R. Listeria monocytogenes serotype identification by PCR. J. Clin. Microbiol., v. 41, n. 12, p. 5537-40, 2003.

BORUCKI, M. K.; PEPPIN, J. D.; WHITE, D.; LOGE, F.; CALL, D. R. Variation in biofilm formation among strains of Listeria monocytogenes. Appl. Environ. Microbiol., v. 69, n. 12, p. 7336-42, 2003.

BOTTONE, E. J. Yersinia enterocolitica: the charisma continues. Clin. Microbiol. Rev., v. 10, n. 2, 1997.

BREMER, P. J.; MONK, I.; BUTLER, R. Inactivation of Listeria monocytogenes / Flavobacterium spp. biofilms using chlorine: impact of substrate, $\mathrm{pH}$, time and concentration. Lett. Appl. Microbiol., v. 35, p. 321-5, 2002.

BRENNER, D. J.; BERCOVIER, H.; URSING, J.; ALONSO, J. M.; STEIGERWALT, A. G.; FANNING, G. R.;CARTER, G. P.; MOLLARET, H. H. Yersinia intermedia: a new species of Enterobacteriaceae composed of rhamnose-positive, melibiose positive, raffinose-positive strains (formerly called atypical Yersinia enterocolitica or Yersinia enterocolitica-like). Curr. Microbiol., v. 4, p. 207-12, 1980.

BUBERT, A.; RIEBE, J.; SCHNITZLER, N.; SCHÖNBERG, A.; GOEBEL, W.; SCHUBERT, P. Isolation of catalase-negative Listeria monocytogenes strains from listeriosis patients and their rapid identification by anti-p60 and/or PCR. J. Clin. Microb., v. 35, n. 1, p. 179-83, 1997.

BUNČIĆ, S. The incidence of Listeria monocytogenes in slaughtered animals, in meat, and in meat products in Yugoslavia. Int. J. Food Microbiol., v. 12, p. 173-80, 1991.

CABANES, D.; DUSSURGET, O.; DEHOUX, P.; COSSART, P. Auto, a surface associated autolysin of Listeria monocytogenes required for entry into eukaryotic cells and virulence. Mol. Microb., v. 51, n. 6, p. 1601-1614, 2004.

CHASSEIGNAUX, E.; GÉRAULT, P.; TOQUIN, M. -T.; SALVAT, G.; COLIN, P.; ERMEL, G. Ecology of Listeria monocytogenes in the environment of raw poultry meat and raw pork meat processing plants. FEMS Microbiol. Lett., v. 210, p. 271-5, 2002. 
CHASSEIGNAUX, E.; TOQUIN, M. -T.; RAGIMBEAU, C.; SALVAT, G.; COLIN, P.; ERMEL, G. Molecular epidemiology of Listeria monocytogenes isolates collected from the enviroment, raw meat and raw products in two poultry- and pork-processing plants. J. Appl. Microbiol., v. 91, p. 888- 99, 2001.

CHRISTIE, R.; ATKINS, N. E.; MUNCH-PETERSEN, E. A note on lytic phenomenon shown by Group B streptococci. Aust. J. Exp. Biol. Med. Sci., v. 22, p. 197-200, 1944.

COSSART, P. Actin-based motility of pathogens: the Arp $2 / 3$ complex is a central player. Cell Microbiol., v. 2, p. 195-205, 2000.

DAUPHIN, G.; RAGIMBEAU, C.; MALLE, P. Use of PFGE typing for tracing contamination with Listeria monocytogenes in threee cold-smoked salmon processing plants. Int. J. Food Microb., v. 64, p. 51-61, 2001.

DE ZOYZA, A.; EFTRATIOU, A. Use of amplified fragment length polymorphisms for typing Corynebacterium diphtheriae. J. Clin. Microbiol., v. 38, p. 3843- 5, 2000.

DEGENHARDT, R.; SANT'ANNA, E. S. Survival of Listeria monocytogenes in low acid Italian sausage produced under Brazilian conditions. Braz.. J. Microbiol., v. 38, p. 309-14, 2007.

DEVENISH, J. A.; SCHIEMANN, D. A. An abbreviated scheme for identification of Yersinia enterocolitica isolated from food enrichment on CIN (cefsulodin-irgasannovobiocin) agar. Can. J. Microbiol., v. 27, p. 937-41, 1981.

DUVAL, E. H.; LIMA, A. S.; GANDRA, E. A.; ARAÚJO, M. R.; MACEDO, M. R. P.; SILVA, W. P. Listeria monocytogenes e Salmonella spp em matéria-prima suína utilizada na produção de lingüiça frescal. In: CONGRESSO BRASILEIRO DE VETERINÁRIOS ESPECIALISTAS EM SUÍNOS, 11., 2003, Goiânia, Anais..., 2003, v. 2 , p. 67-8.

ERDOGAN, H. M.; CRIPPS, P. J.; MORGAN, K. L. Optimization of a culture technique for the isolation of Listeria monocytogenes from fecal samples. J. Vet. Med. Sci. B, v. 49, p. 502-6, 2002.

ESPER, M. R. N. R.; PESSOA, G. V. A.; HOFER, E.; LEE, I. M. L.; MELLES, C. E. A.; SAKATA, E. E.; CALZADA, C. T. Meningite por Listeria monocytogenes em São Paulo, Brasil. Rev. Inst. Adolfo Lutz, v. 38, p. 37-41, 1978. 
FALCÃO, J. P.; FALCÃO, P. Importância de Yersinia enterocolitica em microbiologia médica. Rev. Ciênc. Farm. Básica Apl., v. 27, n. 1, p. 9-19, 2006.

FALCÃO, J. P.; FALCÃO, D. P.; PITONDO-SILVA, A.; MALASPINA, A. C.; $\mathrm{BROCCHI}, \mathrm{M}$. Molecular typing and virulence markers of Yersinia enterocolitica strains from human, animal and food origins isolated between 1968 and 2000 in Brazil. J. Med. Microbiol., v. 55, p. 1539-48, 2006.

FARBER, J. M.; PETERKIN, P. I. Listeria monocytogenes, a food-borne pathogen. Microbiol. Rev., v. 55, n. 3, p. 476-511, 1991.

FREDRIKSSON-AHOMAA, M.; BUCHER, M.; HANK, C.; STOLLE, A.; KORKEALA, $\mathrm{H}$. High prevalence of Yersinia enterocolitica 4 O:3 on pig offal in Southern Germany: a slaughtering technique problem. System. Appl. Microbiol., v. 24, p. 457-63, 2001a.

FREDRIKSSON-AHOMAA, M.; HALLANVUO, S.; KORTE, T.; SIITONEN, A.; KORKEALA, $\mathrm{H}$. Correspondence of genotypes of sporadic Yersinia enterocolitica bioserotype 4/O:3 strains from human and porcine sources. Epidemiol. Infect., v. 127 , p. 37-41, 2001b.

FREDRIKSSON-AHOMAA, M.; KOCH, U.; KLEMM, C.; BUCHER, M.; STOLLE, A. Different genotypes of Yersinia enterocolitica 4/O:3 strains widely distributed in butcher shops in the Munich area. Int. J. Food Microbiol., v. 95, p. 89-94, 2004.

FREDRIKSSON-AHOMAA, M.; KORKEALA, H. Low occurence of pathogenic Yersinia enterocolitica in clinical, food, and environmental samples: a methodological problem. Clin. Microbiol. Rev., v. 16, n. 2, p. 220-9, 2003.

FREDRIKSSON-AHOMAA, M.; KORTE, T.; KORKEALA, H. Contamination of carcasses, offals, and the environment with yadA-positive Yersinia enterocolitica in a pig slaughterhouse. J. Food Prot., v. 63, n. 1, p. 31-5, 2000.

FREDRIKSSON-AHOMAA, M.; NISKANEN, T.; BUCHER, M.; KORTE, T.; STOLLE, A.; KORKEALA, H. Different Yersinia enterocolitica 4:O3 genotypes found in pig tonsils in southern Germany and Finland. System. Appl. Microbiol., v. 26, p. 132-7, 2003.

FREDRIKSSON-AHOMAA, M.; STOLLE, A.; KORKEALA, H. Molecular epidemiology of Yersinia enterocolitica infections. FEMS Immunol. Med. Microbiol., v. 47, p. 31529, 2006. 
FREDRIKSSON-AHOMAA, M.; STOLLE, A.; STEPHAN, R. Prevalence of pathogenic Yersinia enterocolitica in pigs slaughtered at a Swiss abattoir. Int. J. Food Microbiol., v.119, p. 207-12, 2007.

FUKUSHIMA, H.; GOMYODA, M.; ALEKSIC, S.; TSUBOKURA, M. Differentiation of Yersinia enterocolitica serotype 0:5, 27 strains by phenotypic and molecular techniques. J. Clin. Microbiol., v. 31, p. 1672-4, 1993.

GELLIN, B. G.; BROOME, C. V.; BIBB, W. F.; WEAVER, R. E.; GAVENTA, S.; MASCOLA, L.; LISTERIOSES STUDY GROUP. The epidemiology of listerioses in the United States - 1986. Am. J. Epidemiol., v. 133, p. 392-401, 1991.

GIOVANNACCI, I.; RAGIMBEAU, C.; QUEGUINER, S.; SALVAT, G.; VENDEUVRE, J. -L.; CARLIER, V.; ERMEL, G. Listeria monocytogenes in pork slaughtering and cutting plants use of RAPD, PFGE and PCR-REA for tracing and molecular epidemiology. Int. J. Food Microbiol., v. 53, p. 127-40, 1999.

GLASS, K. A.; DOYLE, M. P. Listeria monocytogenes in processed meat products during refrigerated storage. Appl. Environ. Microbiol., v. 55, p. 1565-9, 1989.

GOULET, V.; ROCOURT, J.; REBIERE, I.; JACQUET, C.; MOYSE, C.; DEHAUMONT, P.; SALVAT, G.; VEIT, P. Listeriosis outbreak associated with the consumption of rillettes in France. J. Infec. Dis., v. 177, p. 155-160, 1998.

GRAY, M. L.; KILLINGER, A. H. Listeria monocytogenes and listeric infections. Bacteriol. Rev., v. 30, p. 309-82, 1966.

GÜRTLER, M.; ALTER, T.; KASIMIR, S.; LINNEBUR, M.; FEHLHABER, K. Prevalence of Yersinia enterocolitica in fattening pigs. J. Food Prot., v. 68, n. 4, p. 850-4, 2005.

HARIHARAN, H.; GILES, J. S.; HEANEY, S. B.; LECLERC, S. M.; SCHURMAN, R. $D$. Isolation, serotypes, and virulence-associated properties of Yersinia enterocolitica from the tonsils of slaughter hogs. Can. J. Vet. Res., v. 59, p. 161-6, 1995.

HOF, H. Therapeutic activities of antibiotics in listeriosis. Infection, v. 19, p. 229-33, 1991.

HOFER, E.; LÁZARO, N. S. Anti-Yersinia enterocolitica serotype 3 agglutinins in swine sera from Rio de Janeiro. Pesq. Vet. Bras., v. 17, n. 1, p. 9-11, 1997. 
HOFER, E.; NASCIMENTO, R. S.; OLIVEIRA, M. A. Meningite por Listeria monocytogenes. Relato de casos em pacientes do Distrito Federal. Rev. Soc. Bras. Med. Trop., v. 31, n. 2, p. 173-7, 1998.

HOFER, E.; REIS, C. M. F.; HOFER, C. B. Sorovares de Listeria monocytogenes e espécies relacionadas, isoladas de material clínico humano. Rev. Soc. Brasil. Med. Trop., v. 39, n. 1, p. 32-7, 2006.

HOFER, E.; RIBEIRO, R.; FEITOSA, D. P. Species and serovars of the genus Listeria isolated from different sources in Brazil from 1971 to 1997. Mem. Inst. Oswaldo Cruz, v. 95, n. 5, p. 615-20, 2000.

HOLAH, J. T.; TAYLOR, J. H.; DAWSON, D. J.; HALL, K. E. Biocide use in the food industry and the disinfectant resistance of persistent strains of Listeria monocytogenes and Escherichia coli. J. Appl. Microbiol., v. 92, p. 111-20, 2002.

IIDA, T. KANZAKI, M.; NAKAMA, A.; KOKUBO, Y.; MARUYAMA, T.; KANEUCHI, C. Deteccion of Listeria monocytogenes in humans, animals and foods. J. Vet. Med. Sci., v. 60, n. 12, p. 1341-3, 1998.

JACQUET, C.; CATIMEL, B.; BROSCH, R.; BUCHRIESER,C.; DEHAUMONT, P.; GOULET, V.; LEPOUTRE, A.; VEIT, P.; ROUCORT, J. Investigations related to the epidemic strain involved in the French listeriosis outbreak in 1992. Appl. Environ. Microb., v. 57, p. 2109-13, 1995.

JAY, J. M. Prevalence of Listeria spp. in meat and poultry products. Food Control, v. 7, n. 4/5, p. 209-14, 1996.

JUNTTILA, J. R.; NIEMALA, S. I.; HIRN, J. Minimum growth temperature of Listeria monocytogenes and non-haemolytic Listeria. J. Appl. Bacteriol., v. 65, p. 321-7, 1988.

KANUGANTI, S. R.; WESLEY, I. V.; REDDY, P. G.; MCKEAN, J.; HURD, H. S. Detection of Listeria monocytogenes in pigs and pork. J. Food Prot., v. 65, n. 9, p.1470-4, 2002.

KAPPERUD, G. Yersinia enterocolitica in food hygiene. Int. J. Food Microbiol., v. 12, p. 53-66, 1991. 
KAPPERUD, G.; NESBAKKEN, T.; ALEKSIC, S.; MOLLARET, H. H. Comparasion os restriction endonuclease analysis and phenotypic typing methods for differentiation of Yersinia enterocolitica isolates. J. Clin. Microbiol., v. 28, p. 112531, 1990.

KECHAGIA, N.; NICOLAOU, C.; IOANNIDOU, V.; KOURTI, E.; IOANNIDIS, A.; LEGAKIS, N. J.; CHATZIPANAGIOTOU, S. Detection of chromosomal and plasmid encoded virulence determinants in Yersinia enterocolitica and other Yersinia spp. isolated from food animals in Greece. Int. J. Food Microbiol., v. 118, p. 326-31, 2007.

KETO-TIMONEN, R.; TOLVANEN, R.; LUNDÉN, J.; KORKEALA, H. Na 8-year surveillance of the diversity and persistence of Listeria monocytogenes in a chilled food processing plant analyzes by amplified fragment lenght polymorphism. J. Food Prot., v. 70, n. 8, p. 1866-73, 2007.

KWAGA, J. K. P.; IVERSEN, J. O. Laboratory investigation of virulence among strains of Yersinia enterocolitica and related species isolated from pigs and pork products. Can. J. Vet. Res., v. 38, p. 92-7, 1992.

LAMBERTZ, S. T.; DANIELSSON-THAM, M. -L. Identification and characterization of pathogenic Yersinia enterocolitica isolates by PCR and pulsed-field gel electrophoresis. Appl. Environ. Microbiol., v. 71, n. 7, p. 3674-81, 2005.

LANDGRAF, M.; IARIA, S. T.; FALCÃO, D. P. An improved procedure for the isolation of Yersinia enterocolitica an related species from milk. Int. J. Food Microbiol., v. 56, p. 447-50, 1993.

LAITENEN, O.; TUUHEA, J.; AHVONEN, P. Polyarthritis associated with $Y$. enterocolitica: clinical features and laboratory findings in nine cases with severe joint symptoms. Ann. Rheum. Dis., v. 31, p. 34-9, 1972.

LEAL, N. C.; HOFER, E.; COSTA, M. F.; SÁ, A. T. Isolamento de Listeria monocytogenes em líquido cefalorraquidiano em Recife, Pernambuco, Brasil. Rev. Microbiol., v. 14, p. 280-91, 1983.

LEAL, T. C. A.; LEAL, N. C.; ALMEIDA., A. M. P. Ausência de Yersinia enterocolitica em alimentos, e reservatórios animais, em áreas do estado de Pernambuco, Brasil. Rev. Soc. Bras. Med. Trop., v. 30, p. 193-6, 1997. 
LECUIT, M.; DRAMSI, S.; GOTTARD, C.; FEDOR-CHAIKEN, M.; GUMBINER, B.; COSSART, P. A single amino acid in E-cadherin responsible for host specificity towards the human pathogen Listeria monocytogenes. The EMBO J., v. 18, n. 14, p. 3956-63, 1999.

LECUIT, M.; VANDORMAEL-POURNIN, S.; LEFORT, J.; HUERRE, M.; GOUNON, P.; DUPUY, C.; BABINET, C.; COSSART, P. A transgenic model for listeriosis: role of internalin in crossing the intestinal barrier. Science, v. 292, p.1722-5, 2001.

LIAN, C.; HWANG, W. S.; PAI, C. H. Plasmid-mediated resistance to phagocytosis in Yersinia enterocolitica. Infect. Immun., v. 55, p. 1176-83, 1987.

LIU, D. Identification, subtyping and virulence determination of Listeria monocytogenes, an important foodborne pathogen. J. Med. Microbiol., v. 55, p. 64559, 2006.

LIU, D.; LAWRENCE, M. L.; AINSWORTH, A. J.; AUSTIN, F. W. Toward an improved laboratory definition of Listeria monocytogenes virulence. Int. J. Food Microbiol., v. 118, p. 101-15, 2007.

LORBER, B. Listeriosis. Clin. Infect. Dis., v. 24, p. 1-11, 1996.

LOW, J. C.; DONACHIE, W. A review of Listeria monocytogenes and listeriosis. Vet. J., v. 153, p. 9-29, 1997.

LUNDÉN, J. M.; MIETTINEN, M. K.; AUTIO, T. J.; KORKEALA, H. J. Persistent Listeria monocytogenes strains show enhanced adherence to food contact surface after short contact times. J. Food Prot., v. 63, n. 9, p. 1204-7, 2000.

MANTLE, M.; HUSAR, S. D. Adhesion of Yersinia enterocolitica to purified rabbit and intestinal mucin. Infect. Immun., v. 57, p. 2340-6, 1993.

MARSHALL, D. L.; SCHMIDT, R. H. Growth of Listeria monocytogenes at $10^{\circ} \mathrm{C}$ in milk preincubated with selected pseudomonas. J. Food Prot., v. 51, p. 277-282, 1988.

MCINTYRE, M.; NNOCHIRI, E. A case of hospital-acquired Yersinia enterocolitica gastroenteritis. J. Hosp. Infect., v. 7, p. 299-301, 1986. 
MCLAUCHLIN, J. Human listeriosis in Britain, 1967-85, a summary of 722 cases. 1. Listeriosis during pregnancy and in the newborn. Epidemiol. Infect., v. 104, p. 1819, 1990.

MCLAUCHLIN, J. The relationship between Listeria and listeriosis. Food Control, v. 7, n. 4/5, p. 187-93, 1996.

MCNALLY, A.; DALTON, T.; LA RAGIONE, R. M.; STAPLETON, K.; MANNING, G.; NEWELL, D. G. Yersinia enterocolitica isolates of differing biotypes from humans and animals are adherent, invasive and persist in macrophages, but differ in cytokine secretion profiles in vitro. J. Med. Microbiol., v. 55, p. 1725-34, 2006.

MENDONÇA, C. L.; LÁZARO, N. S.; DUQUE, V. M.; HOFER, E. Fatores de virulência em Yersinia enterocolitica $\mathrm{O}: 3$ isoladas de suínos sadios, Rio de Janeiro. Pesq. Vet. Bras., v. 15, n. 1, p. 11-4, 1995.

MEREGHETTI, L.; QUENTIN, R.; MARQUET - VAN DER MEE, N.; AUDURIER, A. Low sensitivity of Listeria monocytogenes to quaternary ammonium compounds.

Appl. Environ. Microbiol., v. 66, p. 5083-6, 2000.

MILLER, V. L.; FALKOW, S. Evidence for two genetic loci in Yersinia enterocolitica that can promote invasion of epithelial cells. Immun., v. 56, p. 1242-8, 1988

MORRIS, I. J.; RIBEIRO, C. D. Listeria monocytogenes and patê. Lancet, v. li, p. 1285-6, 1989.

MURRAY, E. G. D.; WEBB, R. A.; SWAN, M. B. R. A disease of rabbits characterizd by large mononuclear leucocytosis, caused by a hytherto undescribes bacillus, Bacterium monocytogenes (n. sp.). J. Pathol. Bacteriol., v. 29, p. 407-439, 1926.

NAKAMA, A.; MATSUDA, M.; ITOH, T.; KANEUCHI, C. Molecular typing of Listeria monocytogenes isolated in Japan by pulsed-field gel electrophoresis. J. Vet. Med. Sci., v. 60, n. 6, p. 749-752, 1998.

NESBAKKEN, T. Enumeration of Yersinia enterocolitica O:3 from the procine oral cavity, and its occurrence on cut surfaces of pig carcasses and the environment in a slaughterhouse. Int. J. Food Microbiol., v. 6, p. 287-93, 1988. 
NESBAKKEN, T.; ECKNER, K.; HØIDAL, H. K.; RØTTERUD, O. -J. Occurrence of Yersinia enterocolitica and Campylobacter spp. in slaughter pigs and consequences for meat inspetion, slaughtering, and dressing procedures. Int. J. Food Microbiol., v. 80 , p. 231-40, 2003.

NESBAKKEN, T.; IVERSEN, T.; ECKNER, K.; LIUM, B. Testing of pathogenic Yersinia enterocolitica on the natural dynamic of infection. Int. J. Food Microbiol., v. 111, p. 99-104, 2006.

NIEMAN, R. E.; LORBER, B. Listeriosis in adults: a changing pattern. Report of eight cases and review of the literature, 1968-1978. Rev. Infect. Dis., v. 2, p. 207-27, 1980.

NORBERG, A. N.; MAURE, E. A. P.; SVAITER, N.; GONÇALVES, A. S.; SANCHES, F. G. Listeria monocytogenes in HIV-infected patients in a hospital of Nova Iguaçu, Rio de Janeiro, Brasil. J. Venom. Anim. Toxins incl. Trop. Dis., v. 11, n. 4, p. 6014, 2005.

NORWOOD, D. E.; GILMOUR, A. The growth and resistance to sodium hypochlorite of Listeria monocytogenes insteady-state multispecies biofilm. J. Appl. Microbiol., v. 88, p. 512-5, 2000.

NOWAK, B.; VAN MUEFFLING, T.; CASPARI, K.; HARTUNG, J. Validation of a method for the detection of virulent Yersinia enterocolitica and their distribuition in slaughter pigs from conventional and alternative housing systems. Vet. Microbiol., v. 117, p. 219-28, 2006.

PAIXÃO, R. Isolamento e caracterização de amostras de Listeria monocytogenes em sistemas de produção de suínos e abatedouros. 2006. Dissertação (Mestrado) - Faculdade de Medicina Veterinária e Zootecnia, Universidade de São Paulo, São Paulo, 2006.

PEEL, M.; DONAHIE, W.; SHAW, A. Temperature-dependente expression of flagella of Listeria monocytogenes studied by electron microscopy, SDS-PAGE and western blotting. J. Genetic. Microbiol., v. 143, p. 2171-8, 1988.

PETTINATI, N. N. Listeria monocytogenes em salsichas tipo hot dog, comercializadas no município de São Paulo - análise comparativa e retrospectiva com os isolados de casos de listeriose humana. 2004. Dissertação (Mestrado) - Faculdade de Medicina Veterinária e Zootecnia; Universidade de São Paulo, São Paulo, 2004. 
PIMENTA, F. C.; FURLANETTO, S. M. P.; MAYER, L. W.; TIMENETSKY, J.; SANTOS, M. A. A. Molecular characterization of Listeria monocytogenes isolated from foods. Rev. Microbiol., v. 30, p. 356-61, 1999.

PIVA, J. P.; MAIA, T. R.; BRUGGER, E.; DIAS, C. C.; MATUSIAK, R. Listeriose neonatal. A propósito de um caso. J. Pediat., v. 62, p. 128-30, 1987.

RATNAM, S.; MERCER, E.; PICCO, B.; PARSONS, S.; BUTLER, R. A nosocomial outbreak of diarrheal disease due to Yersinia enterocolitica serotype 0:5, byotipe 1 . J. Infect. Dis., v. 145, p. 242-7, 1982.

ROBINS-BROWNE, R. M.; TAKEDA, T.; FASAND, A.; BORDUN, A.; DOHI, S.; KASUGA, H.; FONG, G.; PRADO, V.; GUERRANT, R. L.; MORRIS JR.; J. G. Assessment of enterotoxin production by Yersinia enterocolitica and identification of a novel heat-stable enterotoxin produced by a noninvasive $Y$. enterocolitica strain isolated from clinical material. Infect. Immun., v. 61, p. 764-7, 1993.

ROMANOVA, N.; FAVRIN, S.; GRIFFITHS, M. W. Sensitivity of Listeria monocytogenes to sanitizers used in the meat processing industry. Appl. Enviorn. Microbiol., v. 68, p. 6405-9, 2002.

RYSER, E.T.; MARTH, E. H. Listeria, Listeriosis and Food Safety. New York: Marcel Dekker, Inc., 1991. 632p.

SAMMARCO, M. L.; RIPABELLI, G.; RUBERTO, A.; IANNITTO, G.; GRASSO, G. M. Prevalence of Salmonellae, Listeriae, and Yersiniae in the slaughterhouse environment work surfaces, equipment, and workers. J. Food Prot., v. 60, n. 4, p. 367-71, 1997.

SCHIEMANN, D. A. Yersinia enterocolitica and Yersinia psudotuberculosis, p. 60172. In: M. P. DOYLE (ed.), Foodborne bacterial pathogens. Marcel Dekker, Inc., New York, N. Y., 1989.

SCHLECH, W. F.; LAVIGNE, P. M.; BOTOLUSSI, R. A.; ALLEN, A. C.; HALDANE, E. V.; WORT, A. J.; HIGHTOWER, A. W.; JOHNSON, S. E.; KING, S. H.; NICHOLLS, E. S.; BROOME, C. V. Epidemic listeriosis - evidence for transmission by food. N. Engl. J. Med., v. 308, p. 203-6, 1983.

SCHWAB, J. P.; EDDELWEISS, M. I. A. Identificação de Listeria monocytogenes em placentas humanas e espécimes de aborto pela técnica de imunoistoquímica. J.

Bras. Patol. Med. Laborat., v. 39, n. 2, p. 111-4, 2003. 
SEELIGER, H. P. R.; HÖHNE, K. Serotyping of Listeria monocytogenes and related species. Meth. Microb., v. 13, p. 31-49, 1979.

SILVA, M. C. D.; DESTRO, M. T.; HOFER, E.; TIBANA, A. Characterization and evaluation of some virulence markers of Listeria monocytogenes strains isolated from Brazilian cheeses using molecular, biochemical and serotyping techniques. Int. J. Food Microbiol., v. 63, p. 2075-80, 2001.

SILVA, W. P.; LIMA, A. S.; GANDRA, E. A.; ARAÚJO, M. R.; MACEDO, M. R. P.; DUVAL, E. H. Listeria spp. no processamento de lingüiça frescal em frigoríficos de Pelotas, RS, Brasil. Ciên. Rural, v. 34, n. 3, p. 911-6, 2004.

SINGH, I.; VIRDI, J. S. Production of Yersinia stable toxin (YST) abd distribution of yst genes in biotype $1 \mathrm{~A}$ strains of Yersinia enterocolitica. J. Med. Microbiol., v. 53, p. 1065-8, 2004.

SKJERVE, E.; LIUM, B.; NIELSEN, B.; NESBAKKEN, T. Control of Yersinia enterocolitica in pigs at herd level. Int. J. Food Microbiol., v. 45, p. 195-203, 1998.

SKOVGAARD, N.; MORGEN, C. -A. Detection of Listeria spp. In faeces from animals, in feeds, and in raw foods of animal origin. Int. J. Food Microbiol., v. 6, p. 229-42, 1988.

SKOVGAARD, N.; NØRRUNG, B. The incidence of Listeria spp. In faeces of Danish pigs and minced pork meat. Int. J. Food Microbiol., v. 8, p. 59-63, 1989.

TAUXE, R. V.; WAUTERS, G.; GOOSSENS, V.; VAN NOYEN, R.; VANDE PITTE, J.; MARTIN, S. M.; DE MOL P.; THIERS, G. Yersinia enterocolitica infections and pork: The missing link. Lancet, i. 1129-32, 1987.

TEODORO, V. A. M.; PINTO, P. S. A.; VANETTI, M. C. D.; BEVILACQUA, P. D.; MORAES, M. P.; PINTO, M. S. Aplicação da técnica de PCR na detecção de Yersinia enterocolitica em suínos abatidos sem inspeção. Arq. Bras. Med. Vet. Zootec., v. 58, n. 1, p. 9-14, 2006.

THÉVENOT, D.; DELIGNETTE-MULLER, M. L.; CHRISTIEANS, S.; VERNOZYROZAND, C. Prevalence of Listeria monocytogenes in 13 dried sausage processing plants and theirs products. Int. J. Food Microbiol., v. 102, p. 85-94, 2005. 
THÉVENOT, D.; DELIGNETTE-MULLER, M. L.; CHRISTIEANS, S.; LEROU, S.; KODJO, A.; VERNOZY-ROZAND, C. Serological and molecular ecology of Listeria monocytogenes isolates collected from 13 French pork meat salting-curing plants and theirs products. Int. J. Food Microbiol., v. 112, p. 153-61, 2006.

TOORA, S.; BUDU-AMOAKO, E.; ABLETT, R. F.; SMITH, J. Isolation of Yersinia enterocolitica from ready-to-eat foods and pork by a simple two step procedure.

Food Microbiol., v. 11, p. 369-74, 1994.

URSING, J.; BRENNER, D. J.; BERCOVIER, H.; FANNING, G. R.; STEIGERWALT, A. G.; ALONSO, J. M.; MOLLARET, H. H. Yersinia frederiksenii: a new species of Enterobacteriaceae composed of rhamnose-positive strains (formerly called atypical Yersinia enterocolitica and Yersinia enterocolitica-like). Curr. Microbiol., v. 4, p., 213-8, 1980.

VASSEUR, C.; RIGAUD, N.; HEBRAUD, M.; LABADIE, J. Combined effects of $\mathrm{NaCl}$, $\mathrm{NaOH}$, and biocides (Monolairin or Lauric acid) on inativaction of Listeria monocytogenes and Pseudomonas spp. J. Food Prot., v. 64, p. 1442-5, 2001.

VELANI, S.; ROBERTS, D. Listeria monocytogenes and other Listeria spp. in prepackaged mixed salads and individual salad ingredients. PHLS Microbiol. Digest., v. 8, p. 21-2, 1991.

WAGNER, M.; ALLERBERG, F. Characterization of Listeria monocytogenes recovered from 41 cases of sporadic listeriosis in Austria by serotyping and pulsedfield gel electrophoresis. FEMS Immun. Med. Microbiol., v. 35, p. 227-34, 2003.

WAUTERS, G.; KANDOLO, K.; JANSSENS, M. Revised biogrouping scheme of Yersinia enterocolitica. Contrib. Microbiol. Immunol., v. 9, p. 14-21, 1987.

WAUTERS, G.; JANSSENS, M.; STEIGERWALT, A. G.; BRENNER, D. J. Yersinia mollaretii sp. nov. and Yersinia bercovieri sp. nov., formerly called Yersinia enterocolitica biogroups 3A e 3B. Int. J. Syst. Bacteriol., v. 38, p. 424-9, 1988 a.

WAUTERS, G.; GOOSSENS, M.; JANSSENS, M.; VANDEPITTE, J. New enrichment method for isolation of pathogenic Yersinia enterocolitica serogroup 0:3 from pork. Appl. Environ. Microbiol., v. 54, p. 851-4, 1988b.

WEBER, A.; KNAPP, W. Nachweis von Yersinia enterocolitica und Yersinia pestis in Kotproben gesunder Schlachtschweine in Abhängigkeit von der Jahreszeit. Zbl. Vet. Med. B, v. 28, p. 407-13, 1981. 
WEISSFELD, A. S.; SONNENWIRTH, A. C. Yersinia enterocolitica in adults with gastrointestinal disturbances. Need for cold enrichment. J. Clin. Microbiol., v. 11, p. 196-7, 1980.

WESLEY, I. V.; HARMON, K. M.; RAMOS, A.; DICKSON, J. Application of a multiplex PCR assay for the simultaneous confirmation of Listeria species and Listeria monocytogenes. J. Food Prot., v.65, p. 780-5, 2002.

WEYNANTS, V.; JADOT, V.; DENOEL, P. A.; TIBOR, A.; LETESSON, J-. J. Detection of Yersinia enterocolitica serogroup 0:3 by a PCR method. J. Clin. Microbiol., v. 34, n. 5, p. 1224-7, 1996.

WIEDMANN, M. Molecular subtyping methods for Listeria monocytogenes. J. AOAC Int., vol. 85, n. 2, p. 524-32, 2002.

WINBLAD, S. Differentiation of Yersinia enterocolitica strains in subgroups after biochemistry and serology. Contr. Microbiol. Immunol., v. 5, p. 44-9, 1979

YOSHIDA, T.; TAKEUCHI, M.; SATO, M.; HIRAI, K. Typing Listeria monocytogenes by random amplified polymorphic DNA (RAPD) fingerprinting. J. Vet. Med. Sci., v. 61, n. 7, p. 857-60, 1999. 